\title{
Promoting Parents' and Children's Well-Being through Parent-Child Gratitude Interventions
}

Meagan A. Ramsey

Follow this and additional works at: https://researchrepository.wvu.edu/etd

\section{Recommended Citation}

Ramsey, Meagan A., "Promoting Parents' and Children's Well-Being through Parent-Child Gratitude Interventions" (2015). Graduate Theses, Dissertations, and Problem Reports. 6471.

https://researchrepository.wvu.edu/etd/6471

This Dissertation is protected by copyright and/or related rights. It has been brought to you by the The Research Repository @ WVU with permission from the rights-holder(s). You are free to use this Dissertation in any way that is permitted by the copyright and related rights legislation that applies to your use. For other uses you must obtain permission from the rights-holder(s) directly, unless additional rights are indicated by a Creative Commons license in the record and/ or on the work itself. This Dissertation has been accepted for inclusion in WVU Graduate Theses, Dissertations, and Problem Reports collection by an authorized administrator of The Research Repository @ WVU.

For more information, please contact researchrepository@mail.wvu.edu. 
Promoting Parents' and Children's Well-Being through Parent-Child Gratitude Interventions

Meagan A. Ramsey, M.S.

Dissertation submitted to the

Eberly College of Arts and Sciences

at West Virginia University

in partial fulfillment of the requirements for the degree of

Doctor of Philosophy in

Life-Span Developmental Psychology

Amy L. Gentzler, Ph.D., Chair

Julie H. Patrick, Ph.D.

JoNell Strough, Ph.D.

Cheryl McNeil, Ph.D.

Amy Root, Ph.D.

Department of Psychology

Morgantown, West Virginia

2015

Keywords: gratitude, well-being, intervention, parent-child relationship

Copyright 2015 Meagan A. Ramsey 


\begin{abstract}
Promoting Parents' and Children's Well-Being through Parent-Child Gratitude Interventions
\end{abstract}

Meagan A. Ramsey

Gratitude is a positive emotion that leads to enhanced relationship resources and emotional wellbeing for children and adults alike. Given the many benefits of gratitude, researchers have examined several types of gratitude interventions. However, it is unclear how the effectiveness of different gratitude interventions compare for youth or how these interventions operate in the family setting. Therefore, this study examined how parents could cultivate their children's (ages 8-13) gratitude and how two gratitude interventions - counting blessings and relational gratitude - enhanced parents' and children's daily gratitude, relationship satisfaction, and emotional well-being over the course of a week-long intervention and if effects were maintained one week after the intervention. Surprisingly, results indicated that the gratitude interventions had relatively little impact on parents and children, and the impact they did have did not differ from that of the active control condition. However, effective gratitude interventions could have beneficial effects for families due to the many positive outcomes associated with gratitude, so it is imperative that family gratitude interventions continue to be designed and tested. This study provides a starting point for future research to improve on these family gratitude interventions, and a number of possible future directions are highlighted. 


\section{ACKNOWLEDGMENTS}

To the University, College, Department, and Program - I am ever grateful for the countless opportunities and financial support you have provided for myself and my research. To my committee - I so appreciate your time, thoughtful questions, and valuable feedback that pushed me and this project further. To my chair and adviser, Amy Gentlzer - I am especially thankful that I have had the good fortune of having you as my mentor and friend. The numerous opportunities and amazing guidance, encouragement, and unwavering support that you have provided are beyond what I ever could have hoped for from a graduate adviser. To my lab mates, developmental cohort, officemates, and colleagues - I am fortunate to have made this journey with so many wonderful people and to call you all my friends. To my husband - I am the absolute luckiest to have your love, support, understanding, and friendship, and I can never thank you enough for your willingness to join me on this journey and for teaching me to go with the flow and roll with the punches. To my parents, brother, in-laws, and family - thank you for always loving me, believing in me, providing for me, and supporting my decisions even when they take me far from home - you are the best. To all of you who have helped shape me or impacted me in some way over the years, ultimately making this accomplishment possible thank you. 


\section{TABLE OF CONTENTS}

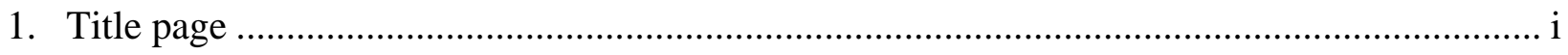

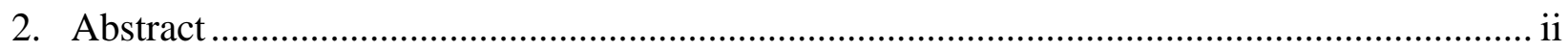

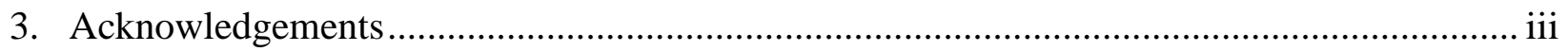

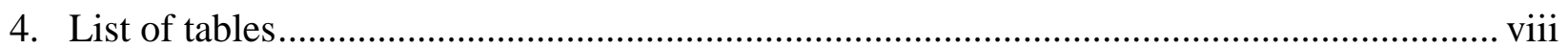

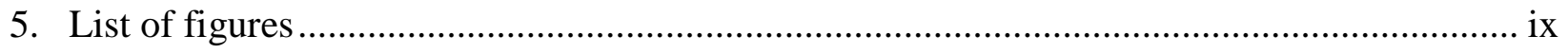

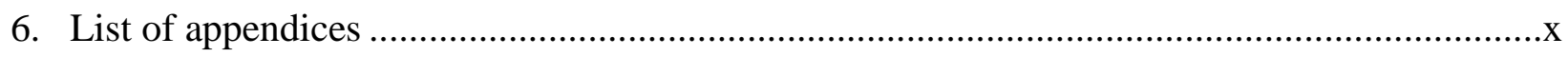

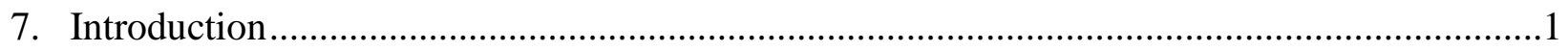

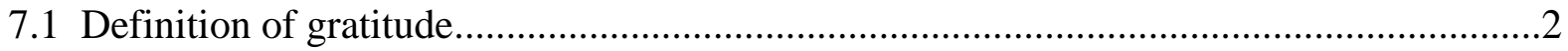

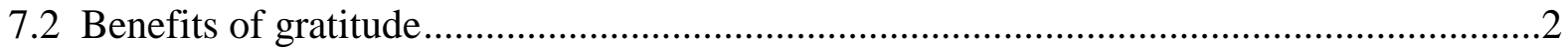

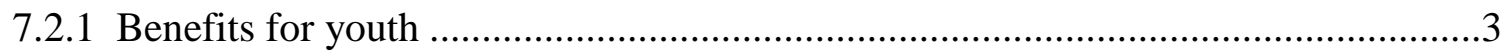

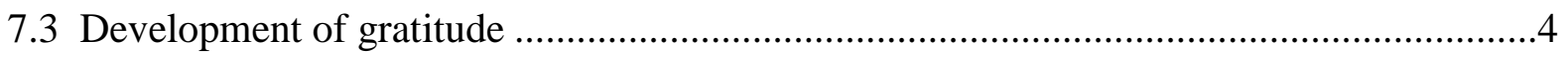

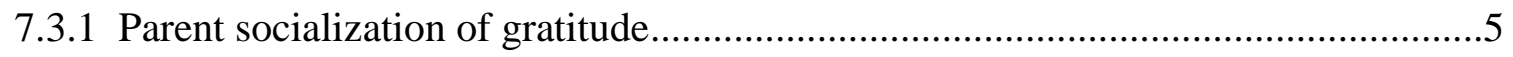

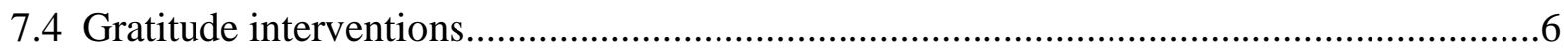

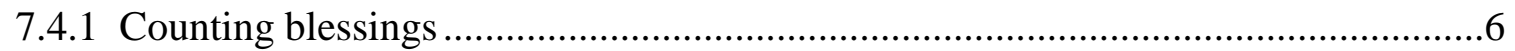

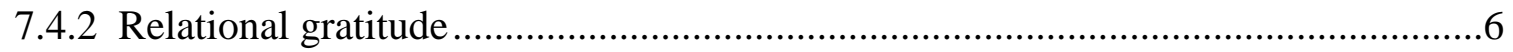

7.5 How does gratitude impact well-being? Relational well-being as a mechanism.................8

7.6 Individual differences: Who benefits the most from gratitude interventions? ..................10

7.6.1 Parent and child initial levels of gratitude and positive affect................................10

7.6.2 Parent motivation .................................................................................................

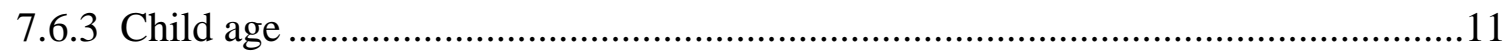

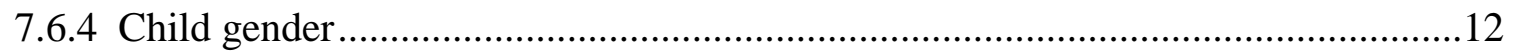

7.7 Do parents and children influence each other? ………...............................................12

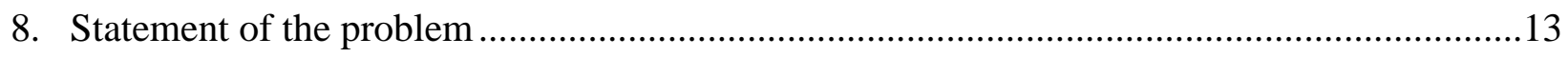

8.1 Research questions and hypotheses .........................................................................

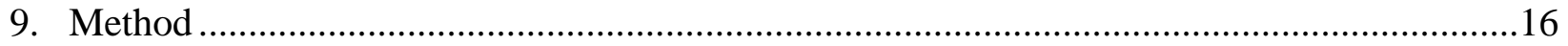

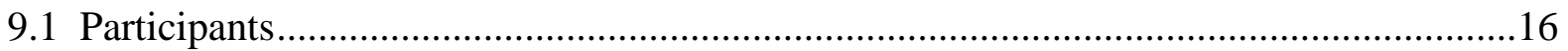

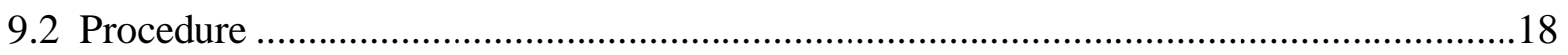

9.2.1 Initial in-person session ……………........................................................19

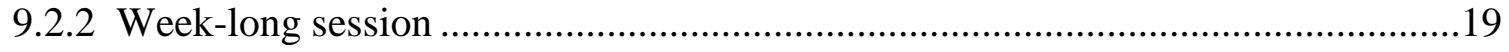

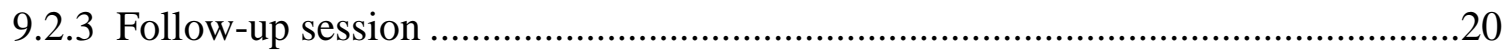




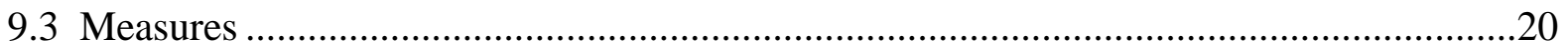

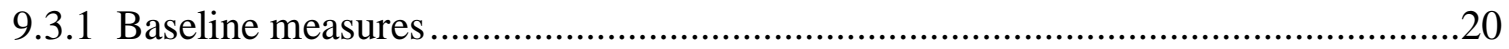

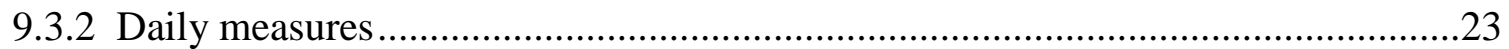

9.3.3 Measures at baseline, day 7, and follow-up .......................................................25

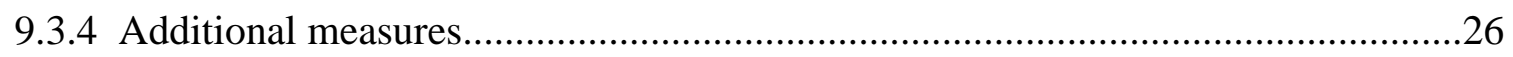

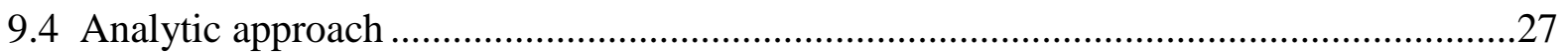

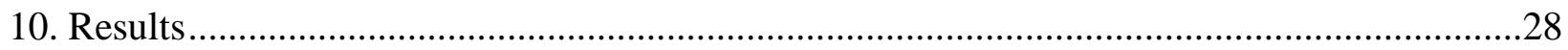

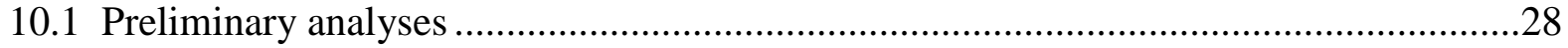

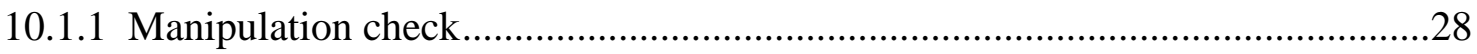

10.1.2 Meeting assumptions for multilevel modeling ..............................................29

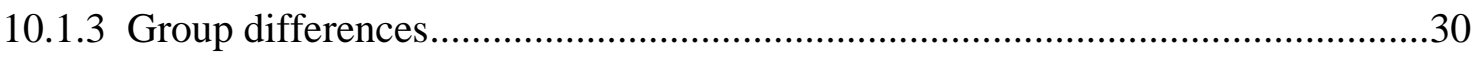

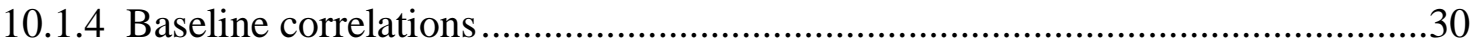

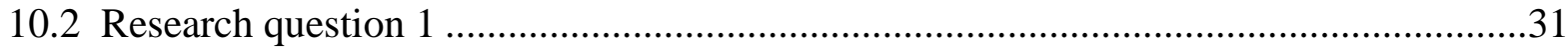

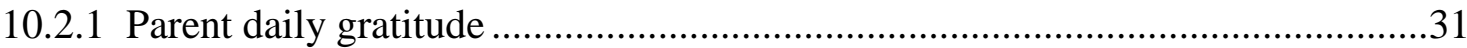

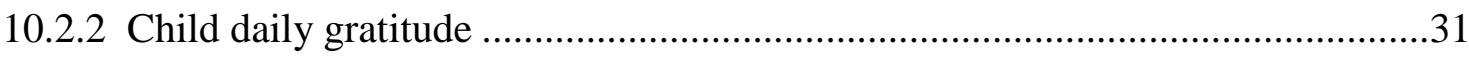

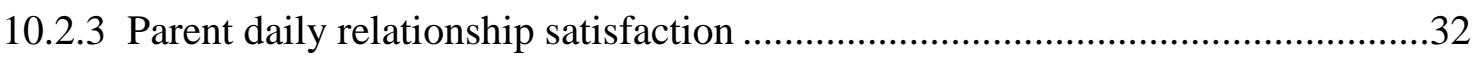

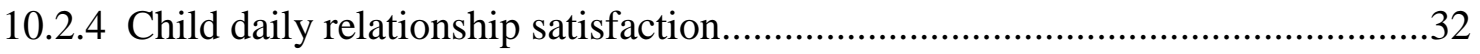

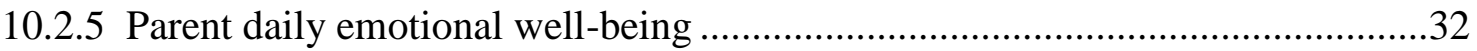

10.2.6 Child daily emotional well-being....................................................................

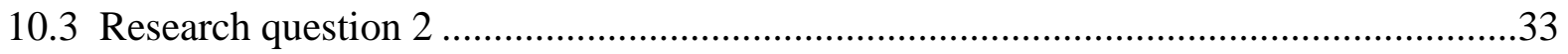

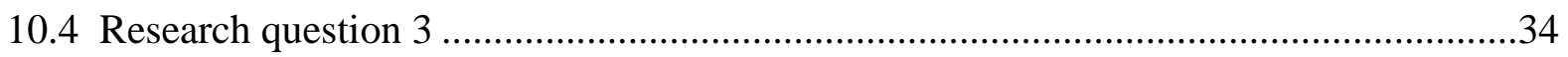

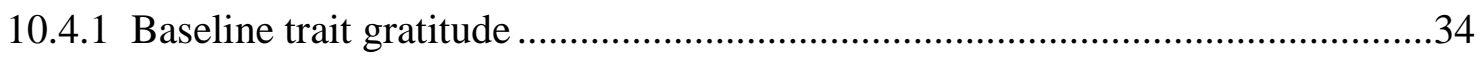

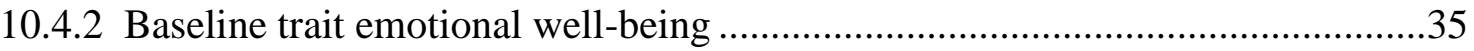

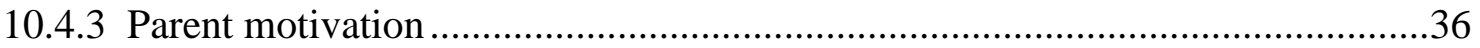

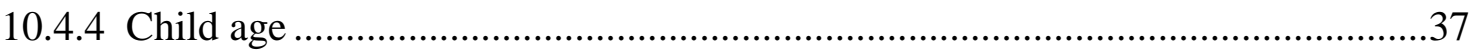

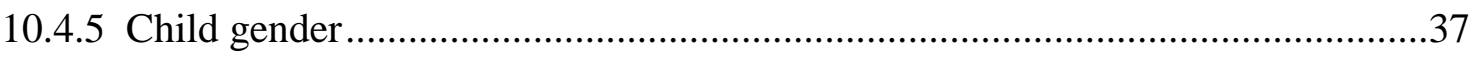

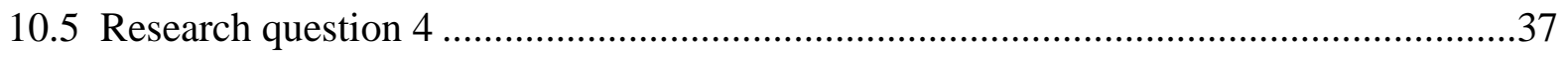

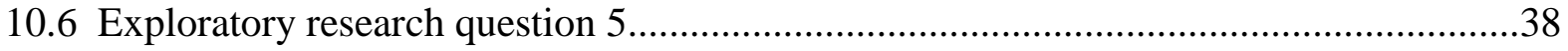

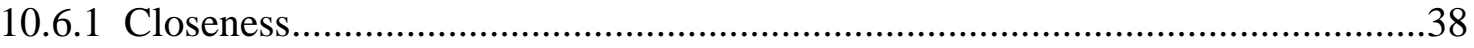

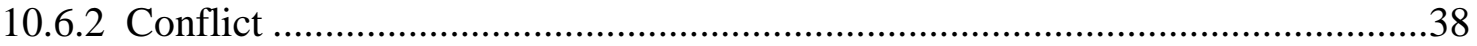

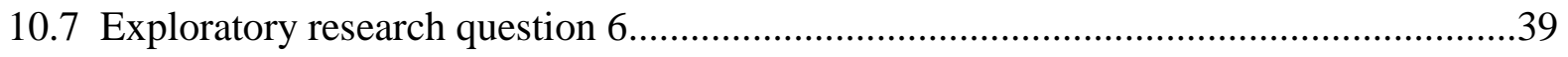

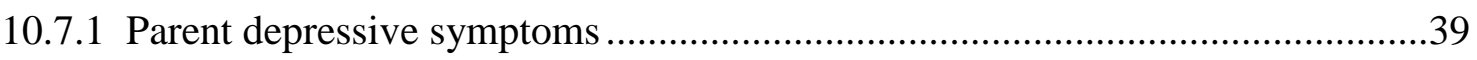




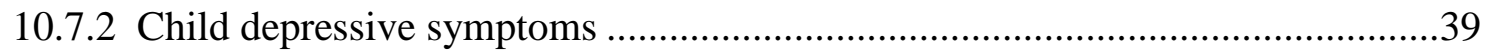

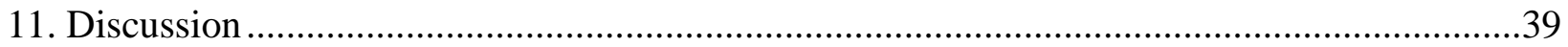

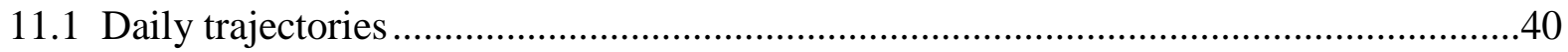

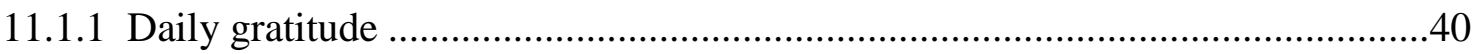

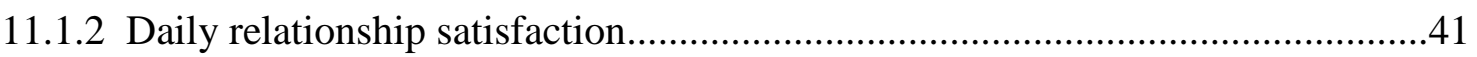

11.1.3 Daily emotional well-being......................................................................

11.2 Indirect effect of relationship satisfaction on gratitude and well-being associations .....42

11.3 Moderators of group by time effects on gratitude and well-being..................................43

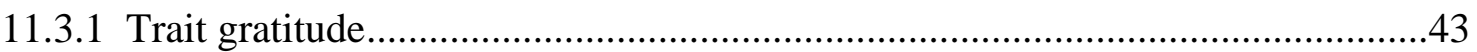

11.3.2 General emotional well-being .....................................................................

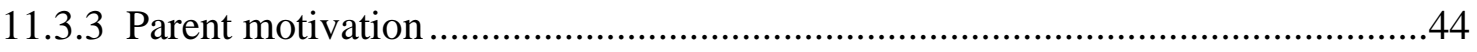

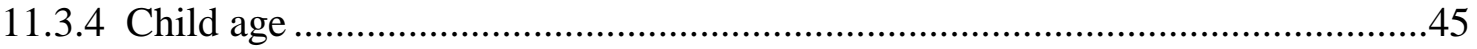

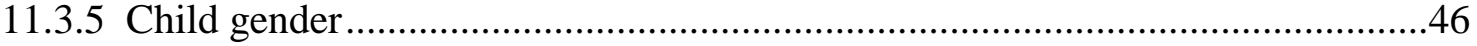

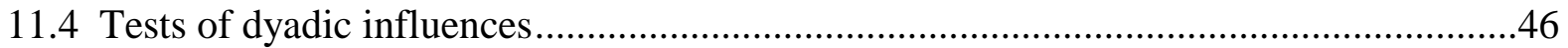

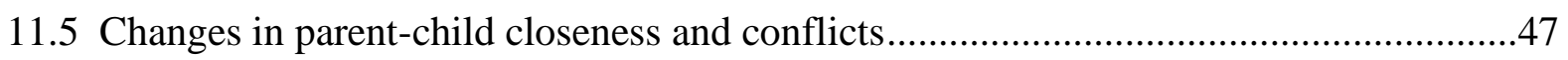

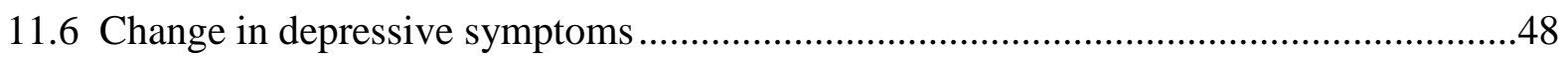

11.7 Reflections on experimental conditions .......................................................................

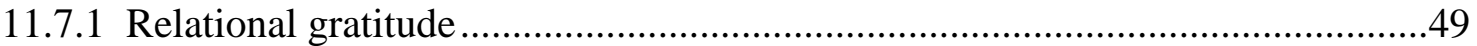

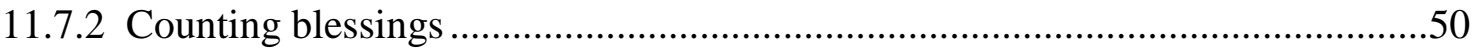

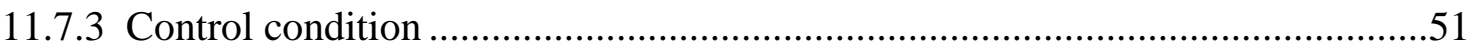

11.8 Methodological considerations, limitations, and future directions ................................52

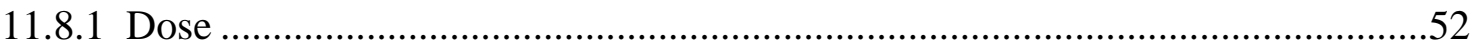

11.8.2 Immediate versus long-term effects ............................................................53

11.8.3 Experimenter expectancies ....................................................................54

11.9 Conceptual considerations, limitations, and future directions .....................................54

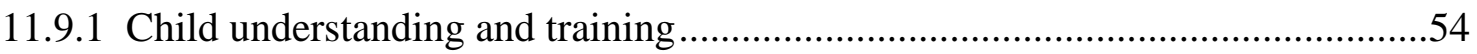

11.9.2 Downsides to youth gratitude interventions? ...................................................55

11.9.3 Best approach for socializing youth gratitude ……..........................................55

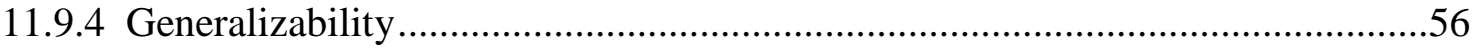

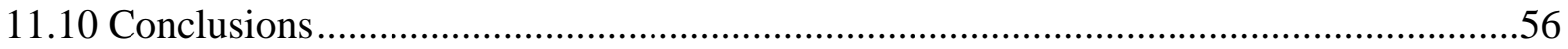

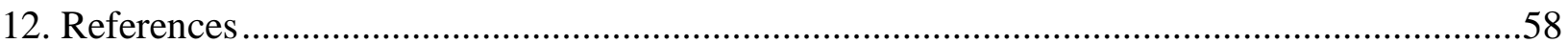

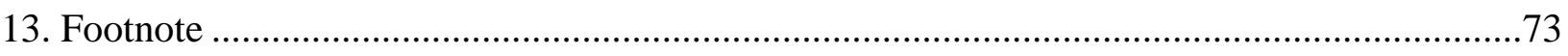


14. Tables .....

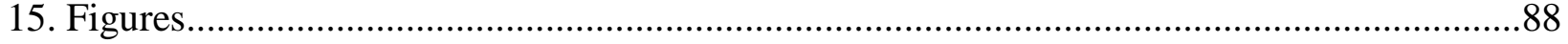

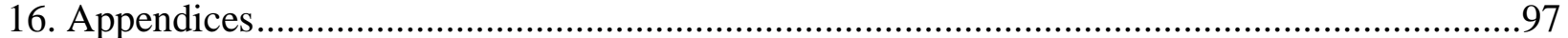




\section{LIST OF TABLES}

1. Table 1: Intraclass Correlation Coefficients (ICC) for all Outcomes ..................................74

2. Table 2: Correlations between Parents' Reports of Daily Gratitude over Time ....................75

3. Table 3: Correlations between Parents' Reports of Daily Relationship Satisfaction over Time

4. Table 4: Correlations between Parents' Reports of Daily Emotional Well-Being over Time 77

5. Table 5: Correlations between Children's Reports of Daily Gratitude over Time .78

6. Table 6: Correlations between Children's Reports of Daily Relationship Satisfaction over Time

7. Table 7: Correlations between Children's Reports of Daily Emotional Well-Being over Time

8. Table 8: Group Comparisons: Demographic Characteristics and Baseline Scores of Interest

9. Table 9: Group Comparisons of Daily Gratitude across the Study ...................................82

10. Table 10: Group Comparisons of Daily Relationship Satisfaction across the Study ............83

11. Table 11: Group Comparisons of Daily Emotional Well-Being across the Study ................84

12. Table 12: Correlations between Baseline Trait and Demographic Variables of Interest .......85

13. Table 13: Multilevel Modeling: Daily Level 1 Variables Predicting Each Other for Parents

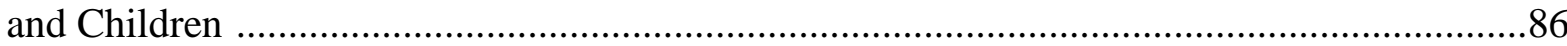

14. Table 14: Actor-Partner Independence Models ..................................................................87 


\section{LIST OF FIGURES}

1. Figure 1: Hypothesized model for research question and hypothesis 2 .............................88

2. Figure 2: Conceptual model for research question 4 and hypotheses $4 \mathrm{a}$ and $4 \mathrm{~b}$...................89

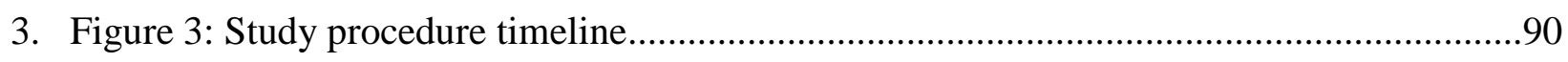

4. Figure 4: Changes in parent and child daily outcomes using survey as a proxy for time .......91

5. Figure 5: Three-way interaction (child baseline trait gratitude $X$ group $X$ time) for child daily

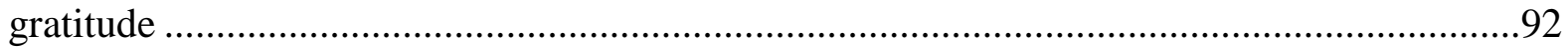

6. Figure 6: Three-way interaction (child baseline trait gratitude $\mathrm{X}$ group $\mathrm{X}$ time) for child daily emotional well-being

7. Figure 7: Three-way interaction (parent motivation $\mathrm{X}$ group $\mathrm{X}$ time) for parent daily gratitude

8. Figure 8: Changes in parent-report of parent-child closeness and conflicts using survey as a proxy for time

9. Figure 9: Changes in parent and child depressive symptoms using survey as a proxy for time 


\section{LIST OF APPENDICES}

1. Appendix A: Relational Gratitude Condition Instructions ………..........................................97

2. Appendix B: Counting Blessings Condition Instructions …….............................................98

3. Appendix C: Control Condition Instructions .....................................................................99

4. Appendix D: Parent Baseline Trait Gratitude: Gratitude Questionnaire-6 ……………..........100

5. Appendix E: Child Baseline Trait Gratitude: Adapted Gratitude Questionnaire-6 ................101

6. Appendix F: Parent Baseline Emotional Well-Being: Satisfaction with Life Scale................102

7. Appendix G: Child Baseline Emotional Well-Being: Students' Life Satisfaction Scale .......103

8. Appendix H: Parent and Child Baseline Emotional Well-Being: Positive and Negative Mood

9. Appendix I: Parent Motivation: Adapted from the Parent Motivation Inventory .................105

10. Appendix J: Parent and Child Daily State Gratitude: Gratitude Adjective Checklist ...........106

11. Appendix K: Parent Daily Relationship Satisfaction...........................................................107

12. Appendix L: Child Daily Relationship Satisfaction …………….........................................108

13. Appendix M: Parent Daily Emotional Well-Being ..................................................................109

14. Appendix N: Child Daily Emotional Well-Being …………………………………..........110

15. Appendix O: Parent-Report of Parent-Child Closeness and Conflicts ...................................111

16. Appendix P: Parent Depressive Symptoms ……………..................................................112

17. Appendix Q: Child Depressive Symptoms ………….....................................................113

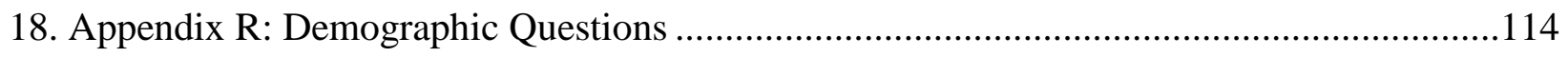

19. Appendix S: Parent-Report of Gratitude-Relevant Behaviors.............................................117

20. Appendix T: Parents' Daily Questions about Conversation Task ........................................118

21. Appendix U: Parent Day 7 and Follow-up Questions .........................................................119 


\section{Promoting Parents' and Children's Well-Being through Parent-Child Gratitude Interventions}

Gratitude is a positive affective state and trait that leads to enhanced emotional wellbeing, enhanced relationship resources, and many other positive outcomes (e.g., Wood, Froh, \& Geraghty, 2010). Researchers have largely focused on testing counting blessings interventions (participants reflect on or write about three to five good things that they are grateful for) to enhance experiences of gratitude, but the literature on relational gratitude interventions (relationship partners express their gratitude to each other) is sparse. It is also unclear how these gratitude interventions influence daily fluctuations in gratitude and emotional well-being over time. Moreover, although a few gratitude interventions have been conducted in youth (Froh, Kashdan, Ozimkowski, \& Miller, 2009a; Froh, Sefick, \& Emmons, 2008; Froh et al., 2014), these gratitude interventions have primarily been tested with adult samples. However, gratitude appears to be as beneficial for children as it is for adults (e.g., Froh et al., 2008), and, as evidenced by the hundreds of articles and books available upon a quick Google search for "how to teach kids to be grateful," cultivating gratitude in their children is an important goal for many caregivers. To address these gaps in the literature, this study examined how gratitude could be cultivated within parent-child dyads through two different gratitude interventions, as well as how these interventions enhanced parents' and children's emotional well-being and the quality of their relationship over time. This study also assessed why these interventions were effective, for whom these interventions were most effective, and how parents' and children's outcomes influenced each other during the intervention period.

\section{Definition of Gratitude}




\section{PROMOTING PARENTS' AND CHILDREN'S WELL-BEING}

Gratitude is a momentary positive emotion that arises when an individual (i.e., beneficiary) recognizes that they have received a benefit due to the goodness of another person (i.e., benefactor) or source (e.g., God, luck; Emmons \& Crumpler, 2000). Gratitude can also be measured as a trait. This dispositional gratitude encompasses a broader orientation to life in which people have a tendency to recognize and appreciate the good things in life (McCullough, Emmons, \& Tsang, 2002; Wood et al., 2010). Research indicates that state and trait gratitude are associated due to characteristic biases in interpreting benefits, such that people higher in trait gratitude tend to interpret received help as more beneficial, more costly to provide, and more altruistically intended. These interpretation biases then lead to more frequent experiences of state gratitude (Wood, Maltby, Stewart, Linley, \& Joseph, 2008b). It is also possible to increase state gratitude using gratitude interventions (e.g., Emmons \& McCullough, 2003).

\section{Benefits of Gratitude}

Gratitude has been linked to a number of benefits for college students and adults, both in correlational and experimental studies. In correlational research, gratitude is associated with greater happiness, life satisfaction, positive affect, and self-esteem (Adler \& Fagley, 2005; Kashdan, Uswatte, \& Julian, 2006; Lambert, Fincham, Stillman, \& Dean, 2009; McCullough, Tsang, \& Emmons, 2004; Toussaint \& Friedman, 2008; Watkins, Woodward, Stone, \& Kolts, 2003; Wood, Joseph, \& Linley, 2007). Gratitude is also associated with a greater sense of coherence, or the belief that life is both manageable and meaningful (Lambert, Graham, Fincham, \& Stillman, 2009). Moreover, gratitude is associated with emotional well-being (high life satisfaction and positive affect) above and beyond the influence of personality characteristics and other socio-demographic characteristics (Datu, 2014; Lin, 2014; McCullough et al., 2002; Wood, Joseph, \& Maltby, 2008a; Wood, Joseph, \& Maltby, 2009). Building on correlational 


\section{PROMOTING PARENTS' AND CHILDREN'S WELL-BEING}

research, experimental manipulations of gratitude also lead to increased happiness, life satisfaction, positive affect, optimism, and self-esteem (Chan, 2010; Emmons \& McCullough, 2003; Lambert et al., 2009; Rash, Matsuba, \& Prkachin, 2011; Seligman, Steen, Park, \& Peterson, 2005; Toepfer, Cichy, \& Peters, 2012; Toepfer \& Walker, 2009; Watkins et al., 2003; Watkins, Uhder, \& Pichinevskiy, 2015).

In addition to being associated with positive outcomes, gratitude is also correlated with lower levels of negative outcomes for adults, including depression (Lambert, Fincham, \& Stillman, 2012; McCullough et al., 2002; Watkins et al., 2003; Wood et al., 2007; Wood et al., 2008b) and aggression (DeWall, Lambert, Pond, Kashdan, \& Fincham, 2012). However, the findings regarding the influences of experimental manipulations of gratitude on negative affect are equivocal. For example, some gratitude interventions have produced decreases in negative affect, depression, and stress (Emmons \& McCullough, 2003 [Study 3]; Chang, Li, Teng, Berki, \& Chen, 2013; Krejtz, Nezlek, Michnicka, Holas, \& Rusanowska, 2014; Seligman et al., 2005; Toepfer et al., 2012; Watkins et al., 2003), but other gratitude interventions have not been successful in decreasing negative affect (Emmons \& McCullough, 2003 [Study 1, 2]; Froh et al., 2014; Chan, 2010).

Benefits for youth. The research that has been conducted for children and adolescents indicates that gratitude has similar benefits for youth. For example, in research on youth character strengths, gratitude is robustly linked to life satisfaction for 10-17 year olds (Park \& Peterson, 2006a, 2006b). Correlational research specifically on gratitude demonstrates that youth (ages 10-19) who experience higher levels of gratitude also have greater life satisfaction, positive affect, and optimism (Chen, 2013; Chen \& Kee, 2008; Froh, Bono, \& Emmons, 2010; Froh, Emmons, Card, Bono, \& Wilson, 2011a; Froh et al., 2011b; Froh, Yurkewicz, \& Kashdan, 


\section{PROMOTING PARENTS' AND CHILDREN'S WELL-BEING}

2009b). Gratitude has also been linked to positive academic outcomes, such as higher GPAs (Froh et al., 2011a). Additionally, higher levels of gratitude are linked to less materialism, envy, and depression in adolescence (Froh et al., 2011a). Findings from experimental manipulations of youths' (ages 8-19) gratitude follow the patterns found in correlational research. Specifically, gratitude interventions successfully increase children's and adolescents' optimism, life satisfaction, and positive affect, and decrease negative affect (Froh et al., 2008, 2009a, 2014). Overall, it appears that enhancing gratitude in children and adolescents could lead to many beneficial outcomes.

\section{Development of Gratitude}

Research on how and when gratitude develops is sparse, but some have suggested that many children may not be capable of experiencing genuine gratitude until middle childhood (i.e., around ages 6 to 8) due to lack of abstract thinking, cognitive limitations regarding theory of mind (i.e., young children may not be able to understand the mental states or intentions of their benefactors), and underdeveloped abilities regarding empathy (Bono \& Froh, 2009; Emmons \& Shelton, 2002; Froh, Miller, \& Snyder, 2007; Lyubomirsky \& Layous, 2014; Watkins, 2014). Several studies support the hypothesis that children are able to start truly understanding and experiencing gratitude around age 8 , and that younger children generally lack a good understanding of gratitude. For example, although younger children (i.e., 3-4 year olds) sometimes spontaneous thank others (Becker \& Smenner, 1986) and 4 to 5 year olds generally do understand that gratitude is a good and pleasurable feeling, most 4 and 5 year olds do not completely understand why people feel gratitude or what situations would cause grateful feelings (Nelson et al., 2012; Russell \& Paris, 1994). Even 6 and 7 year olds struggle with this understanding (Russell \& Paris, 1994). Additionally, older children's experiences and 


\section{PROMOTING PARENTS' AND CHILDREN'S WELL-BEING}

expressions of gratitude seem to be more sophisticated than that of younger children. Regarding children's understanding of gratitude, older children (ages 8-11) better understand the importance of a benefactor's intentionality in gratitude experiences and they are more likely to reciprocate prosocial responses when feeling grateful compared to younger children (ages 5-6; Graham, 1988). During this reciprocation, older children (ages 11-14) are also more likely to take into account the values and desires of the benefactor compared to younger children (ages 710), so the reciprocation may be more meaningful to the benefactor because the favor has not just been paid back in a tit-for-tat fashion (Baumgarten-Tramer, 1938; Freitas, Pieta, \& Tudge, 2011). Additionally, children age 10 and older are more likely to thank others spontaneously compared to children younger than 10 (Gleason \& Weintraub, 1976), and 9-10 year olds are more likely to expect greater gratitude for undesirable gifts on a vignette-based measure compared to 6-7 year olds (Poelker \& Kuebli, 2014). Research has indicated age differences in what children are grateful for as well, with older children (ages 9-12) reporting more gratitude for the important people in their lives and for life itself compared to younger children (ages 4-8; Gordon, Musher-Eizenman, Holub, \& Dalrymple, 2004). Because of the developmental differences in gratitude experiences across childhood, middle to late childhood may be an appropriate period to engage children in a gratitude intervention.

Parent socialization of gratitude. Parents play an important role in socializing and cultivating their children's positive emotions, including gratitude, and this socialization can take several forms including modeling, discussing emotions, and parents' reactions to their children's emotions (Eisenberg, Cumberland, \& Spinrad, 1998; Fredrickson, 1998a). Although little research has specifically examined parents' socialization of gratitude, some researchers have highlighted that parents are instrumental in teaching their children to say "thank you" (Gleason 


\section{PROMOTING PARENTS' AND CHILDREN'S WELL-BEING}

\& Weintraub, 1976). Moreover, Bono and Froh (2009) have proposed that parents can aid their children's understanding of gratitude through conversations with their children, by modeling appreciative behavior, and by engaging their children in activities designed to cultivate gratitude. However, the most effective way for parents to teach their children about gratitude is unknown.

\section{Gratitude Interventions}

Overall, gratitude interventions are effective at increasing feelings of gratitude (e.g., Emmons \& McCullough, 2003). There are several types of gratitude interventions, but it is unknown if one is more effective at promoting gratitude and enhancing well-being than others. We also do not know which type of intervention is most effective for cultivating gratitude in youth, or how these interventions would operate within the family setting.

Counting blessings. In many gratitude interventions, participants engage in a counting blessings task. Generally, participants are asked to reflect on or write about three to five good things that they are grateful for over a certain period of time (Chan, 2010; Emmons \& McCullough, 2003; Lyubomirsky, Sheldon, \& Schkade, 2005; Rash et al., 2011; Seligman et al., 2005; Sheldon \& Lyubomirsky, 2006; Watkins et al., 2003). Despite some studies collecting daily outcomes during these counting blessings interventions (e.g., over 14 days, Emmons \& McCullough, 2002), no researchers have examined the trajectories of daily gratitude and emotional well-being outcomes over the intervention period. Rather, they choose to aggregate the daily data into one composite measure, thus losing valuable information about intraindividual trajectories and inter-individual differences in those trajectories. Froh and colleagues (2008) have also demonstrated the effectiveness of the counting blessings intervention for wellbeing (i.e., life satisfaction and positive and negative affect) in youth (ages 11-13). However, this 


\section{PROMOTING PARENTS' AND CHILDREN'S WELL-BEING}

study was conducted in a school setting, and it is currently unknown how successful parents may be in socializing their children to experience gratitude using a counting blessings activity.

Relational gratitude. Another less common gratitude intervention instructs relationship partners to express their gratitude to each other each day over a specific period of time. Only one study to-date has tested this relational gratitude intervention (Chang et al., 2013). In this study, both members of couples were directed to send emails to their partner expressing appreciation for something based on their interactions with their partner in the previous days. Although the email format of this study is not practical for a similar intervention for parents and children, other studies have used relational gratitude procedures that could be adapted as a parent-child gratitude intervention. For example, in an experimental study focused on friends, Lambert and colleagues (2010) instructed participants to "go the extra mile to express gratitude to your friend" over the course of three weeks, and to "do something you normally wouldn't do to express this gratitude verbally or through writing" (p. 577). As another example, Algoe and colleagues (2013) directed members of couples to choose something nice that the other had done for them recently that they felt grateful for and to thank the other during a conversation. Although this study was not itself an experiment, this type of instruction could be treated as a gratitude intervention task for parents and children.

In a related type of gratitude intervention, participants are instructed to write a letter to someone who has been influential in their lives but who they have never properly thanked (Lyubomirsky, Dickerhoof, Boehm, \& Sheldon 2011; Toepfer et al., 2012; Toepfer \& Walker, 2009; Watkins et al., 2003) and to deliver this letter to their benefactor (Seligman et al., 2005). This intervention is relational in nature, but is much less intense than an intervention that instructs partners to express their gratitude to each other every day. However, it should be 


\section{PROMOTING PARENTS' AND CHILDREN'S WELL-BEING}

mentioned that Froh and colleagues (2009a) have successfully implemented a gratitude letter task in a sample of youth ages 8-19. Specifically, youth (especially those initially low in positive affect) experienced increased gratitude and positive affect after writing and delivering their gratitude letter. Thus, it is likely that youth would benefit from a daily relational intervention as well.

\section{How does Gratitude Impact Well-being? Relational Well-Being as a Mechanism}

Although it is known that gratitude interventions enhance gratitude, and that these feelings of gratitude generally enhance well-being, less is known about why gratitude enhances well-being. Researchers have proposed that one possible mechanism is enhanced social resources (Emmons \& Mishra, 2011). Specifically, experiencing positive emotions such as gratitude enhances relationship satisfaction and feelings of connectedness, and having these positive interpersonal relationships is further predictive of overall emotional well-being (Ramsey \& Gentzler, 2015). To highlight the effects of gratitude on social outcomes, gratitude has been conceptualized as a moral emotion that spurs people to behave more prosocially in the present and future (McCullough, Kilpatrick, Emmons, \& Larson, 2001). Moreover, although beneficiaries often engage in prosocial behaviors to repay their benefactor, researchers have suggested that gratitude may also generate upstream reciprocity whereby unrelated third parties benefit from the beneficiaries' prosocial behavior in a pay-it-forward manner (McCullough, Kimeldorf, \& Cohen, 2008). Research with adults supports these theories, indicating that gratitude leads to increased prosocial behavior towards benefactors (Tsang, 2006) and third parties (Chang, Lin, \& Chen, 2012), largely because gratitude makes people feel more valued (Grant \& Gino, 2010). 


\section{PROMOTING PARENTS' AND CHILDREN'S WELL-BEING}

In line with the broaden and build theory of positive emotions (Fredrickson, 1998b, 2001), these prosocial action-tendencies that accompany experiences of gratitude help people build important social resources that further lead to many positive outcomes and more opportunities to experience gratitude (Fredrickson, 2004). Relatedly, the find-remind-and-bind theory (Algoe, 2012) proposes that gratitude specifically benefits and strengthens both new and existing relationships by helping beneficiaries recognize the good qualities of their benefactor. Research with adults supports these theories as well. Specifically, experiencing gratitude elicits the beneficiary's desire to build the relationship with and give back to the benefactor as well as to others (Algoe \& Haidt, 2009; Bartlett, Condon, Cruz, Baumann, \& Desteno, 2012). Experiencing and expressing gratitude also spurs people to engage in relationship maintenance behaviors such as being more responsive, more committed, and feeling more comfortable in their romantic relationship interactions (Gordon, Impett, Kogan, Oveis, \& Keltner, 2012; Kubacka, Finkenauer, Rusbult, \& Keijsers, 2011; Lambert \& Fincham, 2011). These tendencies and behaviors serve to strengthen bonds and enhance feelings of relationship closeness and satisfaction, as research indicates that experiencing and expressing gratitude enhances relationship well-being in both friendships (Algoe, Haidt, \& Gable, 2008; Lambert, Clark, Durtschi, Fincham, \& Graham, 2010; Lambert \& Fincham, 2011) and romantic relationships (Algoe, Fredrickson, \& Gable, 2013; Algoe, Gable, \& Maisel, 2010; Gordon, Arnette, \& Smith, 2011; Lambert et al., 2010; Murray \& Hazelwood, 2011). Moreover, expressing gratitude to a relationship partner provides relational benefits (i.e., increased relationship connection and satisfaction) for both the beneficiary and the benefactor (Algoe et al., 2010; Algoe et al., 2013).

Despite this body of research highlighting the interpersonal benefits of gratitude for adults, less research has focused on interpersonal benefits for youth, although some research 


\section{PROMOTING PARENTS' AND CHILDREN'S WELL-BEING}

indicates that more grateful youth ages 10-19 report more social support, social integration, and prosocial behavior (Froh et al., 2009b, 2010, 2011a). Overall, it is likely that gratitude leads to greater emotional well-being in part because grateful individuals gain social resources and relationship well-being. These processes are especially relevant for relational gratitude interventions, although it is unclear if similar social benefits would occur for counting blessings tasks.

\section{Individual Differences: Who Benefits Most from Gratitude Interventions?}

Parent and child initial levels of gratitude and positive affect. Research indicates that gratitude interventions are more beneficial (and sometimes only beneficial) for those initially low in gratitude or positive affect. For example, some research indicates that counting blessings interventions are only effective at increasing gratitude, positive affect, and life satisfaction for those with initially low levels of trait gratitude (Chan, 2010; Rash et al., 2011). These findings hold for youth, too. Froh and colleagues (2009a) found that their gratitude visit intervention for $3^{\text {rd }}, 8^{\text {th }}$, and $12^{\text {th }}$ grade students was only effective at increasing gratitude and positive affect for youth who had low baseline positive affect. It should also be noted that some research has found that gratitude interventions are no more effective at enhancing life satisfaction or positive affect than a neutral control, and are only effective when compared to a negative complaining condition which may exaggerate the efficacy of the gratitude manipulations (e.g., Chang et al., 2013; Emmons \& McCullough, 2003; Froh et al., 2008; Sheldon \& Lyubomirsky, 2006). Given the findings from other research (e.g., Chan, 2010), it is possible that the participants in these studies were already high in gratitude or positive affect and thus did not benefit from the gratitude intervention. Taken together, this information suggests that gratitude interventions may only be successful for certain people, especially those low in gratitude and positive affect. 


\section{PROMOTING PARENTS' AND CHILDREN'S WELL-BEING}

Parent motivation. Lyubomirksy and colleagues (2011) have demonstrated that, for gratitude letter-writing interventions, participants' motivation to increase their own well-being explained the effects of the gratitude intervention on well-being. Additionally, those with greater intentions to increase their well-being are more likely to engage in positive activities such as gratitude interventions when given the chance (Kaczmarek et al., 2013). Although some studies find no differences in positive outcomes for gratitude conditions compared to neutral control conditions, one study found medium to large differences between these two conditions in happiness and depression over time (Seligman et al., 2005). For this study, the intervention tasks were described as exercises designed to increase happiness, and the participants were a convenience sample recruited online. Thus, it is likely that these participants had high motivation to increase their happiness (although this was not measured explicitly). These findings may be relevant to parent-child interventions, as parents who are more motivated to increase their own or their child's well-being may also put more effort into their gratitude intervention task and thus experience greater increases in gratitude and emotional well-being.

Child age. In the limited research on the development of gratitude, it appears that older children have a better understanding of gratitude and experience more mature gratitude than younger children (Baumgarten-Tramer, 1938; Freitas et al., 2011; Gleason \& Weintraub, 1976; Gordon et al., 2004; Graham, 1988). In line with this research, it is plausible that older children (e.g., 11-13 year olds) would experience more benefits from a gratitude intervention given their better understanding of the complexities of gratitude. However, because older children may have greater gratitude initially, it is also possible that younger children (e.g., 8-10 year olds) have more room to increase their experiences of gratitude and would thus benefit more. 


\section{PROMOTING PARENTS' AND CHILDREN'S WELL-BEING}

Child gender. Several studies have highlighted gender differences in experiences and expressions of gratitude. For example, in adulthood, women tend to report higher trait gratitude (Kashdan, Mishra, Breen, \& Froh, 2009) and more gratitude to God than men (Krause, 2006). Also, many adult men (especially older men) report that they prefer to hide their gratitude, possibly because they perceive expressions of gratitude as a signal of dependency or weakness (Sommers \& Kosmitzki, 1988). Additionally, women experience more gratitude after receiving a benefit from their partners (Algoe et al., 2010), and they also derive greater well-being from their spouses' expressions of gratitude (Chang et al., 2013). Gender differences in gratitude exist in youth (ages 4-12) as well, with girls reporting more gratitude for the important people in their lives and for religious matters, and less gratitude focused on material objects compared to boys (Gordon et al., 2004). For younger children (3-4), girls are more likely to spontaneous thank others for a gift (Becker \& Smenner, 1986). For older children (11-13 years), girls report slightly more gratitude than boys, but gratitude is more strongly related to family support for boys than for girls (Froh et al., 2009b). Given these gender differences, two scenarios are possible. First, girls may benefit more from a gratitude intervention as they might have a higher propensity for experiencing gratitude. However, it could also be argued that boys may benefit more if they have lower levels of gratitude to begin with or that they may gain more from a relational intervention.

\section{Do Parents and Children Influence Each Other?}

It is clear that parents have a significant influence on their children's gratitude through socializing and cultivating their children's positive emotions (Eisenberg et al., 1998; Fredrickson, 1998a), but it is less clear how children may influence their parents' gratitude experiences. Although children's gratitude is linked to their parents' gratitude (Hoy, Suldo, \& Mendez, 2012), this may not be due entirely to top-down socialization. Some research indicates 


\section{PROMOTING PARENTS' AND CHILDREN'S WELL-BEING}

that children actively influence their parents' experiences of positive emotions (e.g., Grolnick, Cosgrove, \& Bridges, 1996), and these findings may extend to experiences of gratitude as well. Thus, both parents and children would likely play an important role in enhancing each other's gratitude experiences during a family-implemented gratitude intervention.

\section{Statement of the Problem}

Despite the breadth of the current literature on gratitude, there are still several significant areas of inquiry that lack empirical support. Specifically, it is unclear how the effectiveness of different gratitude interventions compare for youth or how these interventions operate in the family setting. Additionally, the trajectories of daily gratitude and emotional well-being during

gratitude interventions have currently not been examined. Furthermore, we know little about why these interventions are effective, or who they are most effective for. Finally, the relative influence that parents and children may have on each other during gratitude conversations is unknown. To fill these gaps in the literature, this study employed experimental, short-term longitudinal methodology to examine the effectiveness of two parent-child gratitude interventions in enhancing both parent and child well-being. Parents and children completed baseline measures of trait and state gratitude, relationship satisfaction, and emotional well-being (life satisfaction and positive and negative affect) during an initial session. Each dyad was assigned to one of three conditions (counting blessings, relational gratitude, and control) and parents also completed a measure of their motivation to engage in the intervention task with their child. For seven days, parents and children completed their intervention task each night, as well as brief measures of daily gratitude, relationship satisfaction, and emotional well-being. Finally, dyads completed similar measures during a one week follow-up. The study addressed four research questions: 


\section{PROMOTING PARENTS' AND CHILDREN'S WELL-BEING}

\section{Research Question 1}

What are the trajectories of parents' and children's daily gratitude, relationship satisfaction, and emotional well-being for the two intervention groups and control group over time?

Hypothesis 1a. Based on prior research demonstrating the effectiveness of gratitude interventions at increasing gratitude (e.g., Emmons \& McCullough, 2003), on average, the trajectory of daily gratitude was expected to increase over the week-long intervention and then level off at the follow-up for the two gratitude interventions, but the control group was expected to have relatively stable daily gratitude for the duration of the study.

Hypothesis 1b. Based on prior research demonstrating associations between gratitude and emotional well-being (e.g., Seligman et al., 2005), on average, the trajectory of daily emotional well-being (i.e., high life satisfaction, high positive affect, and low negative affect) was expected to increase over the week-long intervention and then level off at the follow-up for the two gratitude interventions, but the control group was expected to have relatively stable daily emotional well-being for the duration of the study.

Hypothesis 1c. Based on prior research supporting the find-remind-bind theory (Algoe, 2012), on average, the trajectory of daily relationship satisfaction was expected to increase over the week-long intervention and then level off at the follow-up for the relational gratitude intervention, but the counting blessings and control groups were expected to have relatively stable daily relationship satisfaction for the duration of the study.

\section{Research Question 2}

What mediates the association between daily gratitude and daily emotional well-being? 
Hypothesis 2. In line with theory suggesting the mediating role of enhanced social resources (e.g., Algoe, 2012; Emmons \& Mishra, 2011), parents' and children's daily relationship satisfaction were expected to mediate the association between parents' and children's daily gratitude and their daily emotional well-being for the relational gratitude group only (see Figure 1 for hypothesized model).

\section{Research Question 3}

Do individual differences moderate the influence of the gratitude interventions on parent and child daily gratitude and emotional well-being?

Hypothesis 3a. In line with previous research on initial levels of gratitude and positive affect as a moderator (e.g., Froh et al., 2009a), parents and children who started the study with lower levels of trait gratitude or emotional well-being were expected to experience greater increases in daily gratitude and emotional well-being compared to those who had higher levels of trait gratitude or emotional well-being to being with.

Hypothesis 3b. In line with previous research (e.g., Lyubomirsky et al., 2011), parents who were more motivated to complete the intervention tasks were expected to have greater increases in daily gratitude and emotional well-being for themselves and their child compared to less motivated parents.

Exploratory analysis 3c. Because research indicates age differences in children's gratitude (e.g., Graham, 1988), child age was examined as a potential moderator.

Exploratory analysis 3d. Given previous demonstrations of gender differences in gratitude (e.g., Froh et al., 2009b), child gender was examined as a potential moderator.

\section{Research Question 4}


Does parents' and children's daily gratitude predict the others' daily relationship satisfaction and emotional well-being?

Hypothesis 4a. Based on research demonstrating parents' important role in socializing their children's emotions (e.g., Eisenberg et al., 1998), parents' feelings of daily gratitude were expected to be predictive of their children's daily relationship satisfaction and emotional wellbeing (see Figure 2 for the conceptual model).

Hypothesis 4b. Based on research showing that children influences their parents' positive emotional experiences (e.g., Grolnick et al., 1996), children's feelings of daily gratitude were expected to be predictive of their parent's daily relationship satisfaction and emotional well-being (see Figure 2 for the conceptual model).

\section{Exploratory Research Question 5}

What are the trajectories of parents' perceptions of their closeness and conflicts with their children for the two intervention groups and control group over time?

\section{Exploratory Research Question 6}

What are the trajectories of parents' and children's depressive symptoms for the two intervention groups and control group over time?

\section{Method}

\section{Participants}

Seventy-eight parent-child dyads participated in this study. Children (44 females, 34 males) were ages $8-13(M=10.40, S D=1.58)$ and $75.6 \%$ were Caucasian $(7.7 \%$ African American, $1.3 \%$ Asian, $11.5 \%$ biracial, 3.8\% other). Parents (75 biological mothers, 2 biological fathers, 1 custodial grandmother $)$ were ages $28-59(M=39.71, S D=7.32)$ and $85.9 \%$ were Caucasian (7.7\% African American, 3.8\% Asian, 2.6\% biracial). There was a range of reported 


\section{PROMOTING PARENTS' AND CHILDREN'S WELL-BEING}

income and education, but on average, parents reported a moderate household income ( $25 \%$ reported \$0-49,999 per year, 44.7\% reported $\$ 50,000-99,999$ per year, and 30.3\% reported $\$ 100,000$ and up per year) and were very educated (23.1\% completed some college or less, 43.6\% completed an Associates or Bachelors degree, and 33.3\% completed a Masters or Doctoral degree). Power analyses for this sample size were conducted using GLIMMPSE (University of Colorado Denver, 2012) and indicated that this study was sufficiently powered with 78 dyads, as it could answer the major questions about group differences in trajectories of daily gratitude, relationship satisfaction, and emotional well-being with $85 \%$ power and $5 \%$ error probability.

This sample came from a larger sample of 79 dyads. One parent-child dyad was excluded from analyses because the child chose not to complete baseline measures and the parent withdrew from the study after the initial session. This dyad significantly differed from the rest of the sample in that the parent was a father $\left(\chi^{2}(1, N=79)=25.66, p=.04\right)$, but the dyad did not differ from the rest of the sample on any other demographic characteristics or on the parent's scores on the baseline questionnaires of interest.

On average, parents completed 5.71 out of the first 6 daily surveys on time (before noon the next day). All parents completed at least 4 of the first 6 daily surveys. Two parents did not complete the Day 7 survey and two parents did not complete the 1-week follow-up survey. One child did not complete the Day 7 survey and three children did not complete the 1-week followup survey. These individuals were still included in analyses given the flexibility of multilevel modeling which was used. Validity questions were included in all parent surveys to indicate whether or not parents were paying attention. These questions were embedded in surveys and asked that parents choose a specific answer (e.g., "Please choose three mildly disagree for this"). 


\section{PROMOTING PARENTS' AND CHILDREN'S WELL-BEING}

Three validity questions were included in the longer parent baseline, day 7, and follow-up surveys, and no parents missed more than one out of the three questions, so no parent baseline, day 7 , or follow-up data were excluded. One validity question was included in each of the parents' six short daily surveys, and nine of the 445 completed daily surveys were excluded because parents failed the validity check.

Participants were recruited from the Morgantown $(n=30)$, Pittsburgh $(n=10)$, and Northern Kentucky $(n=10)$ areas through flyers, online, and during community events to take part in a study to enhance parent and child gratitude. Families from past lab studies who had indicated a willingness to participate in future research were also contacted $(n=28)$. Participants were paid up to $\$ 50$ for their participation by the end of the study. Specifically, families received $\$ 10$ for completing the initial in-person session, up to $\$ 30$ for completing the week-long intervention session, and $\$ 10$ for completing the one week follow-up. West Virginia University Institutional Review Board approved this study.

\section{Procedure}

The study consisted of an initial in-person session where parent-child dyads completed surveys and received intervention instructions, a week-long implementation of the intervention task, and a follow-up that took place one week later (see Figure 3 an overview of the timeline and procedure). During the initial session, dyads were randomly assigned to one of three experimental intervention condition tasks (relational gratitude, counting blessings, and control) which they engaged in each night for one week following the initial session. In the relational gratitude condition $(n=26)$, parents and children each shared something that they were grateful for that the other did for them recently (Appendix A). In the counting blessings condition ( $n=$ 24), parents and children each shared something good that they were grateful for (Appendix B). 


\section{PROMOTING PARENTS' AND CHILDREN'S WELL-BEING}

In the control condition $(n=28)$, parents and children each shared something from their day (Appendix C).

Initial in-person session. The initial session of this study took place in the lab $(n=28)$, participants' homes $(n=36)$, or a public location of participants' choosing (e.g., library, restaurant; $n=14$ ). Parent and child participants first provided consent and assent for the study and then completed a set of initial surveys, including assessments of trait and state gratitude, relationship satisfaction, and emotional well-being (i.e., positive and negative affect and life satisfaction). While the parent completed their surveys on the computer, the researcher read the questions to the child and recorded the child's responses on another computer. After completing their surveys, the parent and child then received a packet containing their instructions for the intervention task they were to complete over the week. The researcher read the conversation instructions to the parent and child and asked if they had any questions. Parents and children were each asked to think of an example they could discuss to ensure they understood the intervention task. There were also instructions for the parent's week-long daily diary task and follow-ups (how to access the surveys, when they should be completed, etc.) and a reference sheet for the child's week and follow-up questions. At the end of the session, times to talk with the child during the week and for the follow-up were scheduled. The dyad received $\$ 10$ before leaving the initial session, along with reminder bracelets that had short statements that matched their condition instructions (i.e., "Express Your Thanks," "Count Your Blessings," and "Spend Time Together").

Week-long session. Starting the night of the initial session, parent-child dyads engaged in the intervention task once each night for 7 nights. Parents were reminded of the task and survey each night using a text message reminder service. Each night after engaging in the 


\section{PROMOTING PARENTS' AND CHILDREN'S WELL-BEING}

intervention task, parents completed online daily diaries assessing their daily mood, life satisfaction, and the quality of their relationship with their child for that day. Children were also contacted two times throughout the week (days 3 and 7) by phone to answer brief questions about their daily mood and the quality of their relationship with their parent.

Follow-up session. For the follow-up session, parents and children completed measures assessing a variety of outcomes including gratitude, positive and negative affect, life satisfaction, and relationship satisfaction. Parents completed their follow-up surveys online and children were contacted by phone to answer their follow-up questions. The follow-up session took place one week after the week-long program to determine how the effects of the interventions changed over time. After the follow-up session, participants were debriefed by email, received an electronic flyer with additional information on the study and on cultivating gratitude, and were mailed the remaining incentive (up to $\$ 40$ more).

\section{Measures}

\section{Baseline measures.}

Baseline trait gratitude. Parents completed the Gratitude Questionnaire-6 (GQ-6, McCullough et al., 2002) during the initial session. The GQ-6 is a 6-item measure of dispositional gratitude. Parents responded to items using a 7-point Likert scale from 1 (strongly disagree) to 7 (strongly agree). Example items included, "I have so much in life to be thankful for" and "I am grateful to a wide variety of people." The answers were averaged so that scores were comparable for both parents and children (as children only completed five items), and scores could range from 1-7, with actual scores ranging from 3.5-7 $(M=6.29, S D=.70)$ and higher scores indicating higher trait gratitude $(\alpha=.77)$. See Appendix D.

Children completed the GQ-6 during the initial session as well. Froh and colleagues (2011) have validated this measure for children ages 10-13, and it has been used successfully for 


\section{PROMOTING PARENTS' AND CHILDREN'S WELL-BEING}

children as young as 9 (Hoy et al., 2012). As per the recommendations from Froh and colleagues (2011), item 6 ("Long amounts of time can go by before I feel grateful to something or someone") was not included in the child measure. Also following their recommendations, "thankful" was used instead of "grateful" for all items. The answers were averaged and scores could range from 1-7, with actual scores ranging from 1.6-7 $(M=6.03, S D=.96)$ and higher scores indicating greater trait gratitude $(\alpha=.80)$. See Appendix E.

Baseline emotional well-being. Emotional well-being, generally conceptualized as high life satisfaction, high positive affect, and low negative affect (Diener, Suh, Lucas, \& Smith, 1999), was assessed during the initial session using measures of each of these constructs.

Life satisfaction. Parents completed the Satisfaction with Life Scale (SWLS; Diener, Emmons, Larsen, \& Griffin, 1985) during the initial session as a measure of life satisfaction. Parents responded to 5 items on a 7-point Likert scale ranging from 1 (strongly disagree) to 7 (strongly agree). An example item was, "In most ways, my life is close to my ideal." Answers were averaged and scores could range from 1 to 7 , with actual scores ranging from 1.2-7 $(M=$ $5.14, S D=1.28)$ and higher scores indicating increased life satisfaction $(\alpha=.90)$. See Appendix F.

Children completed the Students’ Life Satisfaction Scale (SLSS; Huebner, 1991) during the initial session as a measure of overall life satisfaction. Children responded to 7 items on a 6point Likert scale from 1 (strongly disagree) to 6 (strongly agree). An example item was, "I have a good life." Answers were averaged and scores ranged from 1 to $6(M=4.89, S D=.83)$, with higher scores indicating greater life satisfaction $(\alpha=.78)$. See Appendix G.

Positive and negative mood. Parents rated the extent that they had felt each of 6 positive and 6 negative emotions in the past week using a 10-point Likert scale from 1 (very slightly or 


\section{PROMOTING PARENTS' AND CHILDREN'S WELL-BEING}

not at all) to 10 (extremely). These positive (excited, cheerful, joyful, happy, proud, calm) and negative (upset, sad, ashamed, nervous, scared, mad) emotion words were taken from the Positive and Negative Affect Schedule - Child version (PANAS-C; Laurent et al., 1999), which was created using the adult PANAS-X (expanded form; Watson \& Clark, 1994). Answers were averaged and scores could range from 1-10 for each subscale, with higher scores indicating greater experience of that affect valence. Actual scores for positive mood ranged from 2.67-10 $(M=7.09, S D=1.68, \alpha=.89)$ and actual scores for negative mood ranged from 1-9.5 $(M=3.01$, $S D=1.73, \alpha=.88)$. See Appendix $\mathrm{H}$.

Children also rated the extent that they had felt each of the same 6 positive and 6 negative emotions in the past week using a 10-point Likert scale from 1 (very slightly or not at all) to 10 (extremely). Each of these emotion words have been used and validated for children in grades 48 (Laurent et al., 1999), and have been used successfully for children as young as 8 (Froh et al., 2014). Answers were averaged and scores could range from 1-10 for each subscale, with higher scores indicating greater experience of that particular affect valence. Actual scores for positive mood ranged from 2.17-10 $(M=7.08, S D=1.68, \alpha=.76)$ and actual scores for negative mood ranged from 1-9.17 $(M=2.77, S D=1.52, \alpha=.82)$. See Appendix $H$.

To obtain a comprehensive assessment of emotional well-being for analyses, a composite emotional well-being score was created for both parents and children. First, averages for baseline negative affect were reversed. Then, z-scores for life satisfaction, positive affect, and reversed negative affect were calculated and summed.

Parent motivation. Parents completed 6 items adapted from the Parent Motivation Inventory (PMI; Nock \& Photos, 2006) during the initial session to assess their motivation to increase their own and their child's gratitude and to engage in the assigned intervention task. 


\section{PROMOTING PARENTS' AND CHILDREN'S WELL-BEING}

Items focused on their child's gratitude were: "I want my child's gratitude to increase," "I am motivated to do this conversation task with my child at home each night for the upcoming week to increase my child's gratitude," and "I believe that doing this conversation task with my child will increase my child's gratitude." Items focused on their own gratitude were: "I want my own gratitude to increase," "I believe that doing this conversation task with my child will increase my own gratitude," and "I am motivated to do this conversation task with my child at home each night for the upcoming week to increase my own gratitude." Parents rated each item on a 6-point Likert scale from 1 (strongly disagree) to 6 (strongly agree). Items were averaged and scores could range from 1-6, with higher scores indicating greater motivation $(\alpha=.85)$. Actual scores only ranged from 4-6 $(M=5.64, S D=.44)$. See Appendix I.

\section{Daily measures.}

Daily state gratitude. Parents completed the Gratitude Adjectives Checklist (GAC; McCullough et al., 2002) to assess state gratitude at all times of measurement. Parents indicated the extent that they felt appreciative, grateful, and thankful for that day using a 10-point Likert scale from 1 (very slightly or not at all) to 10 (extremely). As suggested by other researchers (e.g., Watkins, 2014), these items were incorporated into the daily measure of positive and negative affect so the focus on these specific emotions was less obvious. Answers were averaged and scores could range from 1-10, with actual scores ranging from 1.33-10 $(M=7.34, S D=$ 1.85) and higher scores indicating more daily gratitude $(\alpha=.94)$. See Appendix J.

Children also completed the GAC at all times of measurement to assess their initial state gratitude. This scale has been validated for children ages 10-13 (Froh et al., 2011), but has also been used successfully for children as young as 8 (Froh et al., 2014). The set-up and scoring of 


\section{PROMOTING PARENTS' AND CHILDREN'S WELL-BEING}

this measure was identical to the adult version. Actual scores ranged from 1-10 $(M=6.56, S D=$ 2.43) and higher scores indicated greater daily gratitude $(\alpha=.88)$. See Appendix J.

Daily relationship satisfaction. Parents completed the satisfaction subscale of the Network of Relationships - Relationship Quality Version (NRI-RQV; Buhrmester \& Furman, 2008) at all times of measurement to assess their daily relationship satisfaction with their child. Parents responded to 3 items on an 8-point Likert scale ranging from 1 (not at all) to 8 (extremely much). Items were worded to fit the daily measure and to specify that the questions pertained to their relationship with their child (i.e., "How much do you like the way things have been between you and your child today?" "How happy have you been with your relationship with your child today?" "How satisfied have you been with your relationship with your child today?"). Daily scores were calculated by averaging the 3 items and scores ranged from 2.67-8 $(M=6.67, S D=1.07)$, with higher scores indicating greater daily relationship satisfaction $(\alpha=$ .97). See Appendix K.

Children also completed the satisfaction subscale of the NRI-RQV at all times of measurement to assess their daily relationship satisfaction with their parent. Children responded to the same 3 items on the same 8-point Likert scale ranging from 1 (not at all) to 8 (extremely much). Items were reworded to say "your parent." Daily scores were calculated by averaging the 3 items and scores ranged from 1-8 $(M=6.92, S D=1.27)$, with higher scores indicating greater daily relationship satisfaction $(\alpha=.81)$. See Appendix L.

Daily emotional well-being. Each day, parents and children both answered one item taken from the baseline life satisfaction measures that were reworded to fit the daily measurement. For parents, they answered how much they agreed with, "I am satisfied with my life today," (adapted from the SWLS) on a 7-point Likert scale ranging from 1 (strongly 


\section{PROMOTING PARENTS' AND CHILDREN'S WELL-BEING}

disagree) to 7 (strongly agree). Answers ranged from 1-7 $(M=5.73, S D=1.36)$. Children answered how much they agreed with, "My life has gone well today," (adapted from the SLSS) on a 6-point Likert scale from 1 (strongly disagree) to 6 (strongly agree). Answers ranged from 1-6 $(M=5.21, S D=1.08)$. Parents and children also rated the same 6 positive and 6 negative emotion words used to assess baseline positive and negative mood, but instructions were adapted to reflect the daily measure. Specifically, they each rated the extent that they felt each way for that day using a 10-point Likert scale ranging from 1 (very slightly or not at all) to 10 (extremely). Answers were averaged and scores could range from 1-10 for each subscale. Actual scores for parents' daily positive mood ranged from 1-10 $(M=6.46, S D=1.88, \alpha=.90)$, scores for parents' daily negative mood ranged from 1-8 $(M=2.11, S D=1.30, \alpha=.83)$, scores for children's daily positive mood ranged from 1-10 $(M=6.69, S D=1.98, \alpha=.80)$, and scores for children's daily negative mood ranged from 1-7.17 $(M=1.87, S D=1.11, \alpha=.77)$. See Appendices M (for parents) and $\mathrm{N}$ (for children). As was done for baseline emotional well-being, a composite daily emotional well-being score was created for both parents and children by calculating and summing the z-scores for daily life satisfaction, daily positive affect, and reversed daily negative affect.

\section{Measures at baseline, day 7, and follow-up.}

Parent-child closeness and conflicts. At three different times during the study, parents completed the Child-Parent Relationship Scale (CPRS; Driscoll \& Pianta, 2011; Pianta, 1992) which consisted of 15 items about their relationship with their child that they rated on a 5-point Likert scale from 1 (definitely does not apply) to 5 (definitely applies). Seven of the items assessed closeness, and an example item was, "My child spontaneously shares information about himself/herself." These items were averaged and scores ranged from 2.43-5 $(M=4.30, S D=.59$, 


\section{PROMOTING PARENTS' AND CHILDREN'S WELL-BEING}

$\alpha=.79$ ), with higher scores indicating greater closeness. Eight of them items assessed conflicts, and an example item was, "My child easily becomes angry at me." These items were also averaged and scores ranged from 1-4.38 $(M=2.00, S D=.84, \alpha=.86)$, with higher scores indicating greater conflict. See Appendix O.

Depressive symptoms. At three different times during the study, parents completed the Center for Epidemiological Studies Depression Scale Revised (CESD-R; Van Dam \& Earleywine, 2011; Appendix P), which is a revision of the original CES-D (Radloff, 1977). Parents rated 20 items about how often they felt different ways during the past week on a 4-point Likert scale ranging from 0 (rarely or none of the time, less than 1 day) to 3 (most or all of the time, 5-7 days). This is the scaling from the original CES-D and was used to fit with the timing of the questionnaires. Answers were summed and scores ranged from 0-48, with higher scores indicating greater experience of depressive symptoms $(M=7.39, S D=7.82, \alpha=.90)$. Children completed the Center for Epidemiological Studies_-Depression Scale for Children (CES-DC; Weissman, Orvaschel, \& Padian, 1980; Appendix Q) at three different times during the study. Children also rated 20 items about how often they felt different ways in the past week on a 4point Likert scale from 0 (not at all) to 3 (a lot). Answers were summed and scores ranged from 0-45 $(M=10.01, S D=8.67, \alpha=.89)$.

Additional measures. Several other measures were included in the study that do not pertain to the primary research questions. Parents provided demographic information (Appendix R) and completed measures of their gratitude-relevant behaviors (created for this study, Appendix S), attachment (Experiences in Close Relationships-Revised), and meaning in life (Meaning in Life Questionnaire) at baseline and measures of their relationship with their children (using a different measure - the Network of Relationships Inventory), various aspects of their 


\section{PROMOTING PARENTS' AND CHILDREN'S WELL-BEING}

children's behaviors (Social Skills Improvement System), stress (Perceived Stress Scale), and materialism (Material Values Scale) at baseline, day 7, and follow-up. Children completed measures of motivation (similar to the parent measure) and attachment (using the Kerns Security Scale) at baseline and measures of their relationship with their parents (Network of Relationships Inventory) and materialism (Material Values Scale) at baseline, day 7, and follow-up. Parents and children also completed daily measures of meaning, self-esteem, and social support. At baseline and day 7, parents and children provided their definitions of gratitude. Additionally, parents provided qualitative information about their conversation topics each day during the intervention period and answered several questions about their conversation (Appendix T). Finally, during the day 7 and follow-up assessments, parents indicated if they planned to or had continued the daily conversations and why or why not. They also answered questions about how the conversations had affected them and their children and were given the option to leave any additional comments (Appendix U).

\section{Analytic Approach}

These data were hierarchically nested (i.e., time nested within persons). Multilevel modeling has several advantages for these data: it accounts for the dependency in the data due to nesting; it can account for fluctuations in measurement-completion time across people; it is appropriate for examining differences between unequal subsample sizes; it allows examinations of both linear and nonlinear trajectories; and it is still valid for cases of missing data (e.g., Kwok et al., 2008). Thus, primary analyses utilized multilevel modeling (mixed effects models with random intercepts and slopes) with restricted maximum likelihood estimation (REML) and the Kenward-Roger degrees of freedom approximation (as suggested by Schaalje, McBride, \& Fellingham, 2001) to examine both within-person and between-person variation for the primary 


\section{PROMOTING PARENTS' AND CHILDREN'S WELL-BEING}

research questions. Model building procedures were used for all multilevel models (e.g., Nezlek, 2008). Specifically, first, for all parent and child outcomes being examined, intercepts-only models without predictors were conducted to determine the intraclass correlation coefficients (ICC), or the amount of variance accounted for in each outcome by between-person and withinperson differences. Then, several models with only fixed effects were tested to determine the covariance structure of the data (comparing variance components, compound symmetry, and unstructured models), which was indicated by the model with the smallest Akaike Information Criterion (AIC). Once the covariance structure was determined, random effects and additional effects of interest (e.g., interactions, nonlinear effects, covariates) were added to the model. Nonsignificant effects were dropped to improve the fit of the final model. For models examining trajectories, only the final best-fitting model (i.e., model with the smallest AIC) is discussed. SPSS was used for preliminary analyses. SAS PROC MIXED was used for all primary analyses (see Singer, 1998 for an example of using SAS PROC MIXED for multilevel modeling).

\section{Results}

\section{Preliminary Analyses}

Manipulation check. As a manipulation check, daily qualitative descriptions of the parent-child conversations (provided by the parents each day; see question 4 in Appendix T) were coded using a preliminary coding scheme to examine if the dyad mentioned gratitude. Additionally, any noticeable issues or misunderstandings during the in-person session were noted by the researcher. Based on these manipulation checks, 9 dyads in the control group did not follow their assigned conversation directions (talking about their day generally) and instead discussed things they were grateful for. Thus, these 9 dyads were excluded from analyses ${ }^{1}$ which altered the sample size of the control group $(n=19)$. The 9 dyads excluded from analyses did not 


\section{PROMOTING PARENTS' AND CHILDREN'S WELL-BEING}

significantly differ on any demographic characteristics or any of the baseline questionnaires of interest compared to those included in analyses. Although there was a sizable difference in parents' baseline depressive symptoms, with excluded parents reporting greater depressive symptoms $(M=16.89, S D=17.60)$ than the rest of the sample $(M=8.16, S D=7.81)$, a Levene's test indicated that the assumption of homogeneity of variance was violated $(F=17.12, p<.001)$, and when equal variances were not assumed, the difference was not significant $(t(8.42)=-1.48, p$ $=.18)$.

Meeting assumptions for multilevel modeling. Various procedures were used to check the normality of the data and residuals, the absence of univariate and multivariate outliers, and homogeneity of variance for each time of measurement (e.g., examining histograms, box-plots, and p-p plots; calculating skewness, kurtosis, and Mahalanobis distance). All questionnaire variables of interest, with the exception of children's daily report of gratitude, were skewed for at least one time of measurement. Positively skewed variables were reflected and transformed using either square root or logarithmic transformations depending on the severity of the skewness. Negatively skewed variables were also transformed using either square root or logarithmic transformations. However, modeling with transformed variables did not substantively change the results, so untransformed variables were used for interpretation purposes. Although multilevel modeling handles missing data at the scale level, to address missing data at the item level (less than $1 \%$ ), scale scores were imputed using the individual's mean if at least $75 \%$ of the scale questions were answered (which research suggests is valid with low levels of missing data; e.g.,

Shrive, Stuart, Quan, \& Ghali, 2006).

Spaghetti plots were used to preliminarily examine individual-level trajectories of outcomes for each group. The initial intercepts-only models without predictors indicated that the 


\section{PROMOTING PARENTS' AND CHILDREN'S WELL-BEING}

ICCs for all outcomes were large (Table 1), verifying that clustering (i.e., time within person) was present in the data and justifying the multilevel modeling approach. Additionally, correlations for parents' and children's daily gratitude, relationship satisfaction, and emotional well-being were examined over time to provide preliminary information on the covariance structure of the data (Tables 2-7). The final covariance structure was determined during modeling building procedures, and all models fit best using the variance components covariance structure, which was indicated by the variance components models having the smallest AIC.

Group differences. A series of preliminary ANOVAs and chi square tests were conducted to check for initial differences across the three groups (see Table 8). The three groups did not significantly differ on any demographic characteristics or any of the baseline questionnaires of interest. ${ }^{2}$ Means of the daily variables (gratitude, relationship satisfaction, and emotional well-being) for parents and children in each group are also presented in Tables 9-11 for descriptive purposes.

Baseline correlations. Bivariate correlations were conducted for baseline variables of interest for the full sample $(n=69$; Table 12$)$. These preliminary analyses indicated that parents' and children's baseline reports of trait gratitude, general well-being, and depressive symptoms were not significantly associated. For parents, those with greater trait gratitude also had greater motivation, greater general well-being, lower levels of depressive symptoms, and lower conflicts with their children at baseline. For children, those with greater trait gratitude also reported greater general emotional well-being and lower levels of depressive symptoms at baseline. The only demographic variable that was associated with baseline reports was child age. Specifically, parents reported greater closeness with their children if their children were younger. 


\section{Research Question 1: What are the Trajectories of Parents' and Children's Daily}

Gratitude, Relationship Satisfaction, and Emotional Well-being for the Groups over Time?

To analyze these hypotheses, separate multilevel models (mixed effects models with random intercepts and slopes) were used to examine the trajectories of parents' and children's daily outcomes for each group. Time was assessed using actual day of survey completion rather than using survey number as a proxy for time. To assess group differences in trajectories, the cross-level group by time interaction was examined. For parents' trajectories, linear, quadratic, and cubic effects were examined. Because children only had four waves of data, only linear and quadratic effects were examined for child daily outcomes.

Parent daily gratitude (see Figure 4a). In the models examining parent daily gratitude, the interactions between time (linear, quadratic, and cubic) and group were non-significant and were dropped from the final model. The cubic effect of time was also non-significant and was dropped from the final model. The final model included only main effects for time, time ${ }^{2}$, and group $(\mathrm{AIC}=2074.3)$. There was a marginal main effect for group $(F(2,65.9)=3.08, p=.05)$. Specifically, parents in the control group (intercept $=7.63$ ) reported significantly higher daily gratitude at baseline compared to parents in the relational gratitude group (intercept $=6.57$; $t(64.3)=-2.48, p=.02)$. The counting blessings group (intercept $=7.03)$ did not significantly differ from the control group $(t(66)=-1.30, p=.20)$ or the relational gratitude group at baseline $(t(67.2)=1.21, p=.23)$. There was a significant main effect of time $(F(1,507)=8.78, p=.003)$, with all groups increasing in daily gratitude by .11 points each day. There was also a significant quadratic effect of time $(F(1,471)=5.59, p=.02)$.

Child daily gratitude (see Figure $4 b$ ). In the models examining child daily gratitude, the main effect of group and the interaction between time and group were non-significant and were 


\section{PROMOTING PARENTS' AND CHILDREN'S WELL-BEING}

dropped from the final model. The final model included only main effects for time and time ${ }^{2}$ $(\mathrm{AIC}=1162.5)$. At baseline, children from all groups reported an average of 6.08 for daily gratitude. There was a significant main effect of time $(F(1,176)=12.19, p<.001)$, with all groups increasing in daily gratitude by .21 points each day. There was also a significant quadratic effect of time $(F(1,165)=8.46, p=.004)$.

Parent daily relationship satisfaction (see Figure 4c). In the models examining parent daily relationship satisfaction, the main effects of group, time ${ }^{2}$, and time $\mathrm{s}^{3}$, and the interactions between time (linear, quadratic, and cubic) and group were non-significant and were dropped from the final model. The final model included only the main effect of time (AIC = 1460.9). At baseline, parents from all groups reported an average of 6.64 for daily relationship satisfaction. There was a significant main effect of time $(F(1,75.6)=5.72, p=.02)$, with all groups increasing in daily relationship satisfaction by .01 points each day.

Child daily relationship satisfaction (see Figure 4d). In the models examining child daily relationship satisfaction, there were no main effects of group or time (linear or quadratic) and there were no significant interactions between group and time (linear or quadratic). At baseline, children from all groups reported an average of 7.00 for daily relationship satisfaction and did not change significantly over time.

Parent daily emotional well-being (see Figure 4e). In the models examining parent daily emotional well-being, the main effects of time (linear, quadratic, and cubic) and the interactions between time (linear, quadratic, and cubic) and group were non-significant and were dropped from the final model. The final model included only the main effect of group (AIC = 2377.8). There was a marginal main effect for group $(F(2,65.7)=2.66, p=.08)$. Specifically, parents in the control group (intercept $=.77$ ) reported significantly higher daily emotional well- 


\section{PROMOTING PARENTS' AND CHILDREN'S WELL-BEING}

being at baseline compared to parents in the relational gratitude group $($ intercept $=-.39 ; t(64.3)=$ $-2.29, p=.03$ ). The counting blessings group (intercept $=.01$ ) did not significantly differ from the control group $(t(65.7)=-1.49, p=.14)$ or the relational gratitude group at baseline $(t(65.9)=$ $.83, p=.41)$.

Child daily emotional well-being (see Figure 4f). In the model examining child daily emotional well-being, there were no main effects of group or time (linear or quadratic) and there were no significant interactions between group and time (linear or quadratic). At baseline, children from all groups reported an average of .52 for daily emotional well-being and did not change significantly over time.

\section{Research Question 2: Does Daily Relationship Satisfaction Mediate the Association between Daily Gratitude and Daily Emotional Well-being?}

To analyze this hypothesis, multilevel modeling was conducted using an approach for lower level mediation of a lower level effect outlined by Bauer, Preacher, and Gil (2006). Because there were no group differences in changes in the daily outcomes over time, and because the models would not converge for the groups separately, this modeling was conducted for all groups combined (separately for parents and children). The first step was to determine that, on a within-person level, daily gratitude, daily relationship satisfaction, and daily emotional well-being were all significantly and positively related within a given day. Preliminary models confirmed that all three daily variables were associated for both parents and children (see Table 13). Next, using the approach suggested by Bauer and colleagues (2006) one model was run for parents and one for children, and indirect and total effects were calculated. For parents, results indicated that there was a small but significant indirect effect of daily gratitude on daily emotional well-being through daily relationship satisfaction within any given day $(B=.08, S E=$ 
$.001, p=.012)$, in addition to the total effect of parents' daily gratitude and relationship satisfaction on their emotional well-being $(B=.69, S E=.003, p<.001)$. For children, results also indicated that there was a small but significant indirect effect of daily gratitude on daily emotional well-being through daily relationship satisfaction within any given day $(B=.08, S E=$ $.001, p=.015)$, in addition to the total effect of children's daily gratitude and relationship satisfaction on their emotional well-being $(B=.34, S E=.003, p<.001){ }^{3}$

\section{Research Question 3: Do Individual Differences Moderate the Influence of the Gratitude Interventions on Parent and Child Daily Emotional Well-being?}

To analyze these hypotheses, separate multilevel models were conducted for each potential moderator. Continuous moderators were centered. Cross-level 2-way interactions (moderator by time and moderator by group) were included in the models. To assess group differences in the moderated effects of emotional well-being over time, the cross-level 3-way interactions (group by moderator by time) were examined. The other potential moderators were entered as level 2 time-invariant covariates for each model.

Baseline trait gratitude. For parents, when accounting for main effects of the other potential level 2 moderators (baseline trait emotional well-being and motivation, child age and gender), there was a significant main effect of parents' baseline trait gratitude on parents' daily gratitude intercept $(F(1,69.6)=8.77, p=.004)$, with parents higher in baseline trait gratitude reporting higher daily gratitude at baseline as well $(B=1.20, S E=.53, p=.03)$. There were no significant two- or three-way interactions between parents' baseline trait gratitude and time or group on parent daily gratitude. There were no significant main effects or interactions between parents' baseline trait gratitude, time, and group on their daily emotional well-being. 


\section{PROMOTING PARENTS' AND CHILDREN'S WELL-BEING}

For children's daily gratitude, when accounting for main effects of the other potential level 2 moderators, there was a significant main effect of children's baseline trait gratitude $(F(1$, $82.9)=4.56, p=.04)$. However, this was qualified by a three-way interaction between children's baseline trait gratitude, time, and group $(F(2,126)=4.45, p=.01)$. To further understand this interaction, simple slopes of high and low (+/- $1 S D)$ child trait gratitude were examined by group over time (see Figure 5). Results indicated that children with higher trait gratitude had an increase in daily gratitude over time for all three groups (counting blessings: $B=4.88, S E=1.52$, $p=.02$; relational gratitude: $B=5.35, S E=1.56, p=.01$; control group: $B=3.99, S E=1.50, p=$ .02). Additionally, for children lower in trait gratitude, those in the counting blessings group had an increase in daily gratitude over time $(B=.14, S E=.10, p=.04)$, but those in the relational gratitude group had a decrease in daily gratitude over time $(B=-.28, S E=.11, p=.02)$, and the simple slope was not significant for the control group. For children's daily emotional well-being, there was also a marginal main effect of children's baseline trait gratitude $(F(1,77.7)=3.92, p=$ $.05)$, and this was qualified by a three way interaction between children's baseline trait gratitude, time, and group $(F(2,75.6)=3.96, p=.02)$. Again, simple slopes were examined (see Figure 6) and results indicated that for children with lower trait gratitude, those in the counting blessings group had an increase in daily emotional well-being over time $(B=.17, S E=.13, p=.04)$ but those in the relational gratitude group had a decrease in daily emotional well-being over time $(B$ $=-.19, S E=.11, p=.04)$. No other simple slopes were significant.

Baseline trait emotional well-being. For parents, when accounting for main effects of the other potential level 2 moderators (baseline trait gratitude and motivation, child age and gender), there were no significant main effects or interactions between parents' baseline emotional well-being, time, and group on their daily gratitude. However, for parents' daily 


\section{PROMOTING PARENTS' AND CHILDREN'S WELL-BEING}

emotional well-being, there was a main effect of trait emotional well-being $(F(1,75.3)=48.87, p$ $<.001$ ), with parents higher in baseline trait emotional well-being reporting higher daily emotional well-being at baseline as well $(B=.37, S E=.13, p=.01)$. There were no significant two- or three-way interactions between parents' baseline trait emotional well-being and time or group on parent daily emotional well-being.

For children, when accounting for the main effects of the other potential level 2 moderators, there were no significant main effects or interactions between children's baseline trait emotional well-being, time, and group on their daily gratitude or for their daily emotional well-being.

Parent motivation. For parents, when accounting for main effects of the other potential level 2 moderators (baseline trait gratitude and emotional well-being, child age and gender), there were not significant main effects of parent motivation or two-way interactions between parent motivation and time or group. However, there was a significant three-way interaction between parent motivation, group, and time on parent daily gratitude $(F(2,66.7)=3.15, p=$ .049). To further understand this interaction, simple slopes of high and low (+/- $1 S D)$ parent motivation were examined by group over time (see Figure 7). Results indicated that for parents with lower motivation, those in the counting blessings group had a decrease in daily gratitude over time $(B=-2.18, S E=1.30, p=.04)$ but those in the relational gratitude group had an increase in daily gratitude over time $(B=2.44, S E=1.16, p=.04)$. No other simple slopes were significant. For parent daily emotional well-being, there were no significant main effects or interactions between parents' motivation, time, and group.

For children, there were no significant main effects or interactions between parents' motivation, time, and group on their daily gratitude or daily emotional well-being. 


\section{PROMOTING PARENTS' AND CHILDREN'S WELL-BEING}

Child age. Child age was examined as a potential moderator for both parent and child daily outcomes. However, there were no significant main effects of child age or interactions for parents' or children's daily gratitude or daily emotional well-being.

Child gender. Child gender was examined as a potential moderator for both parent and child daily outcomes. There were no significant main effects of child gender or interactions for parents' daily gratitude or daily emotional well-being. There also were no significant main effects of child gender or interactions for children's daily gratitude. For children's daily emotional well-being, there was a significant main effect of child gender $(F(1,80)=4.01, p=$ $.048)$, with girls reporting significantly higher daily emotional well-being at baseline $(B=.74, S E$ $=.57)$ compared to boys $(B=-.43, S E=.43)$. However, there were no significant interactions between child gender, group, or time for children's daily emotional well-being.

\section{Research Question 4: Does Parents' and Children's Daily Gratitude Predict the Others'}

\section{Daily Relationship Satisfaction and Emotional Well-being?}

To analyze these hypotheses, cross-partner associations were examined using actorpartner interdependence modeling (APIM) within the multilevel modeling framework (e.g., Cook \& Kenny, 2005). Because there were no group differences in changes in the daily outcomes over time, and because the models would not converge for the groups separately, this modeling was conducted for all groups combined. First, stability-influence APIM was conducted for daily gratitude, daily relationship satisfaction, and daily emotional well-being. For all three stability-influence models, the stability estimates were significant for both parents and children, but there were no cross-partner associations (see Table 14). Specifically, parents' gratitude on a previous day was associated with their reported gratitude the next day, and children's gratitude on a previous day was associated with their gratitude the next day, but parents' gratitude on a 


\section{PROMOTING PARENTS' AND CHILDREN'S WELL-BEING}

previous day was not associated with their children's gratitude the next day, and children's gratitude on a previous day was not associated with their parents' gratitude the next day. Similar findings emerged for daily relationship satisfaction and daily emotional well-being, too.

Additionally, different variable APIM was conducted with daily gratitude predicting daily relationship satisfaction, and with daily gratitude predicting daily emotional well-being. For both different variable models with daily gratitude predicting either relationship satisfaction or emotional well-being, there were significant within person associations, but there were no cross-partner associations (see Table 14). Specifically, parents' gratitude on a previous day was associated with their relationship satisfaction the next day, and children's gratitude on a previous day was associated with their relationship satisfaction the next day, but parents' gratitude on a previous day was not associated with their children's relationship satisfaction the next day, and children's gratitude on a previous day was not associated with their parents' relationship satisfaction the next day. Similar findings emerged for previous day gratitude predicting next day emotional well-being, too.

\section{Exploratory Research Question 5: What are the Trajectories of Parents' Perceptions of} Their Closeness and Conflicts with Their Children for the Groups over Time?

Closeness (see Figure 8a). In the models examining parent-report of parent-child closeness, there were no significant main effects of time (using week as a proxy) or group and the interaction between time and group was also non-significant. At baseline, parents from all groups reported an average of 4.32 for closeness with their child and did not change significantly over time.

Conflict (see Figure 8b). In the models examining parent-report of parent-child conflicts, the main effect of group and the interaction between time and group were non-significant and 
were dropped from the final model. The final model included only the main effect of week (AIC =317.7). At baseline, parents from all groups reported an average of 2.23 for conflicts with their child. There was a significant main effect of week $(F(1,132)=23.91, p<.001)$, with all groups decreasing in conflict by .14 points each week.

\section{Exploratory Research Question 6: What are the Trajectories of Parents' and Children's}

\section{Depressive Symptoms for the Groups over Time?}

Parent depressive symptoms (see Figure 9a). In the models examining parent-report of parent-child conflicts, the main effect of group and the interaction between time and group were non-significant and were dropped from the final model. The final model included only the main effect of week $(\mathrm{AIC}=1220.9)$. At baseline, parents from all groups reported an average of 9.46 for depressive symptoms. There was a significant main effect of week $(F(1,130)=10.57, p=$ .002 ), with parents in all groups reporting a decrease in depressive symptoms by 1.49 points each week.

Child depressive symptoms (see Figure 9b). In the models examining child depressive symptoms, there were no significant main effects of time (using week as a proxy) or group and the interaction between time and group was also non-significant. At baseline, children from all groups reported an average of 9.93 for depressive symptoms and did not change significantly over time.

\section{Discussion}

This study examined two gratitude interventions - counting blessings and relational gratitude - in a novel family setting. Overall, the two gratitude interventions did not differ from the control condition on gratitude, relationship satisfaction, emotional well-being, depression, or parent-child closeness and conflicts over time. However, parents and children in all groups did 


\section{PROMOTING PARENTS' AND CHILDREN'S WELL-BEING}

report increases in daily gratitude over time. Parents in all groups also reported an increase in daily relationship satisfaction with their child over time, and reported decreased conflicts with their children and depressive symptoms over time. Despite the limited findings, this study is an important contribution to the field as it provides evidence that family gratitude interventions may need to be structured differently to be more effective than an active control task. This discussion largely focuses on potential reasons why the interventions were no more effective than the control condition and provides suggestions for future research.

\section{Daily Trajectories}

Daily gratitude. Although it was expected that only parents and children in the two gratitude intervention groups would experience an increase in daily gratitude over time, results indicated that parents and children in all groups (including the control group) reported an increase in daily gratitude during the study, and this leveled off over time. Thus, this pattern indicates that the active control condition was just as effective at increasing parents' and children's gratitude. In prior research, gratitude interventions have been effective at increasing gratitude, but this research has been flawed in several ways, including not having a control condition (Chan, 2010) or only using a passive control (Emmons \& McCullough, 2003 [Study 3]). Additionally, a few other studies also indicated that the gratitude interventions were no more effective at increasing gratitude than a neutral (Emmons \& McCullough, 2003 [Study 1]) or downward social comparison control group (Emmons \& McCullough, 2003 [Study 2]), so these findings are consistent with some prior research. Because this was advertised as a study about gratitude, it is possible that these increases in gratitude were driven by parents and children's expectations, even if they were not actively talking about gratitude each night. 


\section{PROMOTING PARENTS' AND CHILDREN'S WELL-BEING}

Daily relationship satisfaction. Although it was expected that only parents in the relational gratitude intervention groups would experience an increase in relationship satisfaction over time (based on prior research with adults, e.g., Algoe et al., 2008, 2013), results indicated that parents in all three groups had a small but significant increase in daily relationship satisfaction with their children during the study. Because theory and research on gratitude proposes that even general gratitude is associated with enhanced social resources (e.g., Fredrickson, 2004; McCullough et al., 2001), the finding that the counting blessings condition enhanced parents' relationship satisfaction is not surprising. It was not expected that simply spending extra time together talking each night (i.e., the control) would impact relationship satisfaction, but it is possible that this was effective if parents and children generally didn't spend much intentional time together. Unexpectedly, children (in any group) did not report an increase in daily relationship satisfaction with their parent over time, but this may be due to ceiling effects in children's report of the relationship satisfaction with their parent at baseline.

Daily emotional well-being. Surprisingly, results indicated that neither parents nor children reported an increase in daily emotional well-being (as measured by daily life satisfaction and daily positive and negative affect) over time. This was unexpected, especially given that all groups increased in daily gratitude. However, other research has mixed findings for how gratitude interventions impact the different components of emotional well-being. Some research shows no differences in positive affect over time, even when comparing to a negative counting hassles control group (Emmons \& McCullough, 2003 [Study 1]) or other control (i.e., making downward social comparisons or reflecting on a past memorable event; Emmons \& McCullough, 2003 [Study 2]; Rash et al., 2011), Additionally, several studies have found that gratitude interventions do not decrease negative affect (Chan, 2010; Emmons \& McCullough, 


\section{PROMOTING PARENTS' AND CHILDREN'S WELL-BEING}

2003 [Study 1, 2]; Froh et al., 2014). However, gratitude interventions are consistently associated with increases in life satisfaction even when compared to active neutral and other control groups (Emmons \& McCullough, 2003; Rash et al., 2011). Although some research does demonstrate that gratitude interventions are effective for more global well-being (e.g., Lyubomirsky et al., 2005), it is also possible in this study that any impact of the interventions on life satisfaction were washed out by including positive and negative affect in the emotional well-being composite. Thus, it may be more beneficial to examine the impact of family gratitude interventions on the different aspects of emotional well-being separately because they are distinct constructs.

\section{Indirect Effect of Relationship Satisfaction on Gratitude and Well-Being Associations}

Consistent with hypotheses, results indicated that, for both parents and children, there was a small but significant indirect path between daily gratitude and daily emotional well-being through daily relationship satisfaction within any given day of the study. These findings were expected based on theory (e.g., Algoe, 2012) and other research on gratitude, relationship qualities, and well-being (e.g., Gordon et al., 2011; Lambert et al., 2010). An important next step will be to determine if relationship satisfaction mediates the association across days in a larger sample that will allow convergence for lagged models. It will also be important to examine other potential mediators of the association between gratitude and emotional well-being. Emmons and Mishra (2011) outlined a number of other possible mediators (e.g., enhanced coping and selfesteem, reduced materialism), but it is unclear if one possible mediator plays a larger role than the others. It was expected that social resources such as relationship satisfaction would be most relevant for this study given the dyadic nature of the tasks, but examining multiple possible mediators in parallel will allow future research to test this question. 


\section{PROMOTING PARENTS' AND CHILDREN'S WELL-BEING}

\section{Moderators of Group by Time Effects on Gratitude and Well-Being}

Trait gratitude. Contrary to expectations, parents' trait gratitude did not moderate group differences in their daily gratitude or emotional well-being over time. However, children's trait gratitude at baseline did moderate group differences in both their daily gratitude and emotional well-being over time. Specifically for children's daily gratitude, children in all three groups with higher trait gratitude at baseline had an increase in daily gratitude over time. These findings contrast previous research with adults showing that gratitude interventions tend to be more beneficial or only beneficial for people who have low trait gratitude (Chan, 2010; Rash et al., 2011). It is unclear why trait gratitude was not a moderator for parents, but for children, it is possible that youth who reported higher trait gratitude at baseline had a better understanding of gratitude and thus got more out of the conversations with their parents. Also in contrast to hypotheses and previous research, children in the relational gratitude condition with lower trait gratitude had a decrease in both daily gratitude and daily emotional well-being over time. Again this was unexpected given that previous research found that gratitude interventions were more beneficial for those lower in trait gratitude (Chan, 2010; Rash et al., 2011). However, it is possible that children who were not very grateful to begin with reacted negatively to being told to thank their parents, especially if they had a difficult time thinking of things to thank their parents for or if this created relational issues. Finally, in line with expectations, children in the counting blessings condition with lower trait gratitude had an increase in both daily gratitude and daily emotional well-being over time. This was expected based on previous research with adults (Chan, 2010; Rash et al., 2011) and supports the idea that counting blessings may be especially beneficial for youth with low trait gratitude. 


\section{PROMOTING PARENTS' AND CHILDREN'S WELL-BEING}

General emotional well-being. Contrary to expectations, parents' and children's general emotional well-being at baseline did not moderate group differences in their daily gratitude or emotional well-being over time. This opposes previous research showing that children and adolescents only benefit from gratitude interventions when they have lower levels of positive affect initially (Froh et al., 2009a). However, in this study, in addition to low positive affect, low initial emotional well-being also consisted of lower life satisfaction and higher negative affect, and the difference in findings may result from the more comprehensive conceptualization of emotional well-being. It is also possible that parents and children who had lower well-being had less effective conversations due to difficulty thinking of topics or less enthusiasm for the conversations, and that this canceled out any benefits that might have come from the conversations.

Parent motivation. When examining parent motivation as a moderator, results indicated that, for parents with lower motivation, those in the counting blessings condition had a decrease in daily gratitude over time, but those in the relational gratitude condition had an increase in daily gratitude over time. These findings were not in line with expectations, as it was hypothesized that parents higher in motivation would experience greater benefits. It is possible that parents with lower motivation in the counting blessings condition had a difficult time coming up with things to be grateful for, and that this adversely impacted their gratitude. However, lower motivation may have been beneficial for parents in the relational gratitude condition as they may have put less pressure on themselves and their children to think of things to thank each other for, which may have been beneficial if this prevented feeling disappointment at what the other said thank you for. Notably, both of these findings are opposite of those for children's trait gratitude, as children lower in trait gratitude and in the counting blessings 


\section{PROMOTING PARENTS' AND CHILDREN'S WELL-BEING}

condition had an increase in daily gratitude and those lower and in the relational gratitude condition had a decrease. However, because there were no baseline associations between parents' and children's trait variables and no cross-partner associations between parents' and children's daily reports, these opposing findings are plausible as it seems that parents and children had different experiences and were affected differently. Also contrary to expectations, parent motivation at baseline did not moderate group differences in parents' daily emotional well-being over time or children's daily gratitude and emotional well-being over time. There was very little variability in parents' motivation (ranged from 4-6 on a 1-6 scale), so this may be one reason that motivation was not a moderator for parents' emotional well-being or children's daily outcomes.

Child age. Although age was an exploratory moderator and there was no clear hypothesis on whether the interventions would be more beneficial for older or younger children (or parents of older or younger children), it was still expected that there would be child age differences in the effect of the conditions over time. However, results indicated that there were no child age differences in parent or child daily gratitude or emotional well-being at baseline, and child age did not moderate group differences in parents' or children's daily gratitude or emotional wellbeing over time. Previous research does indicate that there are age differences in children's understanding and expression of gratitude (Baumgarten-Tramer, 1938; Freitas et al., 2011; Gleason \& Weintraub, 1976; Gordon et al., 2004; Graham, 1988), but no research has examined if gratitude interventions impact children of different ages (or parents of differently aged children) in different ways. This study offers initial insight and suggests that gratitude interventions operate similarly for all children ages 8-13 and their parents. 


\section{PROMOTING PARENTS' AND CHILDREN'S WELL-BEING}

Child gender. Although girls reported higher daily emotional well-being at baseline, there were no child gender difference in parents' or children's daily gratitude at baseline, and child gender did not moderate group differences in parents' or children's daily gratitude or emotional well-being over time. Again, gender was an exploratory moderator as no research has examined gender differences in youth gratitude interventions, but based on previous research on gender differences in gratitude in youth generally (Becker \& Smenner, 1986; Froh et al., 2009b; Gordon et al., 2004), it was expected that the gratitude interventions might operate differently for boys and girls (although there were no clear hypotheses about the interventions being better for boys or girls). This study provides support for the idea that boys and girls are not differentially affected by these interventions, and that parents participating with either sons or daughters have similar experiences.

\section{Tests of Dyadic Influences}

Although there were significant within-person associations indicating the stability of daily gratitude, daily relationship satisfaction, and daily emotional well-being for both parents and children over time, unexpectedly, there were no significant cross-partner associations. Additionally, there were significant within-person associations between daily gratitude and next day relationship satisfaction, as well as between daily gratitude and next day emotional wellbeing, for both parents and children. However, contrary to hypotheses, there were no crosspartner associations. These results indicate that parents' daily experiences were not significantly influencing their children's daily experiences and that children's daily experiences were not significantly influencing their parents' daily experiences. This is surprising given previous research on parent socialization (e.g., Eisenberg et al., 1998) and child-driven influences on parents (e.g., Grolnick, Cosgrove, \& Bridges, 1996). It is also especially surprising given that 


\section{PROMOTING PARENTS' AND CHILDREN'S WELL-BEING}

parents and children were engaging in their assigned conversations together each night rather than counting their blessings or reflecting on their day independently. Potentially, parents and children were more impacted by the conversation topics that they chose for themselves, and although they listened to the others' responses and topics, were not as influenced by what the other person was saying. Another possibility is that parents and children didn't take notice of the others' daily affective or relational experiences, or that slight changes in parents' and children's daily affective and relational experiences were not readily apparent or important to the other.

\section{Change in Parent-Child Closeness and Conflicts}

Results indicated that there were no changes in parents' reports of their closeness with their children over time, but parents in all groups did report decreased conflicts with their children over time. These were exploratory analyses, but based on other gratitude and relational research (e.g., Gordon et al., 2012), it could be expected that having gratitude conversations and spending extra time together could enhance some aspects of the parent-child relationship over time. These results indicate that setting aside intentional time to talk with their children each night (about gratitude or their day), could help parents and children perceive and possibly experience less conflict with each other. This is especially promising given how minimal the interventions were (just a few intentional minutes of conversation each night). Because parents and children were already relatively low in conflict at baseline and there was little variability in baseline conflict for the sample, an important future direction is to examine how these types of interventions might work for high-conflict families. It could be expected that the intervention would be even more beneficial for high-conflict families, but it is also possible that high-conflict families would not approach the conversations in the most ideal way (e.g., it may turn into another opportunity for conflict if the child isn't cooperative) and that parents may need some 


\section{PROMOTING PARENTS' AND CHILDREN'S WELL-BEING}

additional coaching (e.g., like that involved in parent-child interaction therapy; McNeil \& Hembree-Kigin, 2010) to successfully navigate gratitude-related conversations with high-conflict children or children with behavioral problems.

\section{Change in Depressive Symptoms}

Results indicated that parents in all groups experienced a decrease in depressive symptoms over time, but children's depressive symptoms did not change over the course of the study. This is in line with other research in adulthood (Lambert et al., 2012; McCullough et al., 2002; Watkins et al., 2003; Wood et al., 2007; Wood et al., 2008b), although it was unexpected that the control group would experience these benefits. It is important to note that this was a community sample of parents and children and that there was very little variability in parents and children's baseline well-being, so the results may be different for clinical populations.

Specifically, prior research indicated that counting blessings interventions provided a number of benefits (i.e., greater life satisfaction, optimism, and connectedness with others) for a clinical sample, but did not decrease depression across the two week intervention period (Kerr, O’Donovan, \& Pepping, 2015). Moreover, research indicates that depressed individuals may be less likely to self-initiate involvement in a gratitude intervention (Kaczmarek et al., 2013), largely because, although they believe others would approve of their participation, they expect that it would be burdensome and do not believe that it would improve their lives (Kaczmarek, Kashdan, Drazkowski, Bujacz, \& Goodman, 2014). Thus, clinical populations likely require more than a simple gratitude intervention, although it may be beneficial for clinicians to incorporate aspects of gratitude and other positive psychology interventions and therapies into their therapy regimens (e.g., Seligman, Rashid, \& Parks, 2006).

\section{Reflections on the Experimental Conditions}




\section{PROMOTING PARENTS' AND CHILDREN'S WELL-BEING}

Relational gratitude. The relational gratitude intervention was designed based on relational gratitude studies with adults (Algoe et al., 2013; Chang et al., 2013; Lambert et al., 2010) and gratitude letter interventions which have been used with both adults and children (Froh et al., 2009a; Lyubomirsky et al., 2011; Seligman et al., 2005; Toepfer et al., 2012; Toepfer \& Walker, 2009; Watkins et al., 2003). An important part of the relational gratitude intervention was that parents and children both reflected on and talked about the costs incurred and sacrifices made by the benefactor when they engaged in their kind act that the beneficiary was thanking them for. However, it is not clear how much parents and children focused on the effort made by other person during their discussions or how sincere their gratitude expressions were. Forced expressions may not be very beneficial, and could even be harmful if they created the perception of ungratefulness. Another factor that may have played a role in the effectiveness of the relational gratitude interventions is how parents and children responded to the other person's expression of gratitude. For example, if a parent or child responded negatively or with contemptuous sarcasm (e.g., "Nice to finally get some appreciation."), the outcome may have been much worse than if they responded with enthusiasm (e.g., "I am happy to help!") or humility (e.g., "It was nothing.”).

Another possible consideration for the relational gratitude intervention is whether or not the benefactor knows that the beneficiary is expressing their gratitude because of their participation in a study. Often, gratitude letter interventions where study participants write and deliver letters to benefactors that they have not properly thanked have strong and immediate benefits that continue to impact people and only slowly taper off over time (e.g., Seligman et al., 2005). However, for this type of intervention, the benefactor often is not aware that the letterdeliverer was told to do so as part of a study, and knowing that could diminish the individual and 


\section{PROMOTING PARENTS' AND CHILDREN'S WELL-BEING}

interpersonal benefits of the letter-writing and delivery. It is possible that, because parents and children both knew that the other was thanking them because of their involvement in the study, their expressions had less impact than expected. It is also possible the expressions felt less natural or were less effective because they were not in the moment, but rather happened later, possibly hours after the kind act had been given.

Counting blessings. Counting blessings interventions are the most common gratitude interventions and have been effective when people write about (e.g., Emmons \& McCullough, 2003; Seligman et al., 2005) and reflect on things they are grateful for (e.g., Chan, 2010; Sheldon \& Lyubomirsky, 2006; Rash et al., 2011). However, rarely do interventions have people actively talk about things they are grateful for. In research by Watkins and colleagues (2003), they found that grateful thinking was more effective than grateful writing, and they suggested that grateful writing might involve cognitive processes that disrupt positive experiences. Thus, it is possible that the discussion format for gratitude interventions is not as effective as reflecting or even writing if it also engages processes that disrupt the benefits of recalling good experiences. However, the discussion format seems well-suited for parents' socialization of their children's gratitude, as it allows them to point out additional things their children might be grateful for and gives them opportunities to expand on their children's thoughts (e.g., highlighting what the benefactor gave up). Therefore, research should more formally examine these different formats for family gratitude interventions to determine what format is most effect for parents and children.

Another consideration for the counting blessings condition is what types of blessings parents and children were discussing. Although few studies have examined the content of people's grateful thoughts (see Gordon et al., 2004 or Rash et al., 2011 for exceptions), it is 


\section{PROMOTING PARENTS' AND CHILDREN'S WELL-BEING}

possible that talking about lower-level content like material items may be less impactful than discussing higher-level content such as having basic necessities and a good life. A final consideration for both gratitude interventions is that the focus on gratitude could have backfired for parents and children. Specifically if either parents or their children had a difficult time coming up with something they were grateful for that day, they may have felt even less grateful. Similarly, this situation could have made parents realize that their children were even less grateful than they thought they were, which may have had a negative impact. This type of backfire has been found in other research related to emotional well-being. Specifically, people who value happiness highly or are obsessed with being happy often experience less happiness during positive situations because their levels of happiness do not live up to their expectations and they are disappointed (Mauss, Tamir, Anderson, \& Savino, 2011). Thus, during the family gratitude interventions, parents may have been expecting their children to immediately

understand and express high levels of gratitude, and may have experienced disappointment if the conversations did not live up to their expectations, which could have cancelled out some of the benefits of the interventions.

Control condition. The control condition was an active control group. Parents and children were still having discussions and spending the same amount of extra time together as in the two gratitude interventions. This condition may have unintentionally acted as a third relational intervention, especially if parents and children did not normally spend much intentional time together each day. Thus, it will be important for future research to include passive control conditions. Because the study was advertised as a study to enhance family gratitude, there may have been a placebo effect where parents and children experienced benefits from the control condition merely because they expected that spending extra time together would 


\section{PROMOTING PARENTS' AND CHILDREN'S WELL-BEING}

help them be more grateful. Additionally, because of the way the study was advertised, participants may have realized that they were in the control group because they were not asked to talk about gratitude and may have overcompensated or tried harder to make up for their group assignment (e.g., Cook and Campbell, 1979). It is also possible that dyads in the control group talked longer because their topic was broader. Finally, it is likely that parents and children in the control group were talking about generally positive things. Qualitative data are currently being coded to allow analysis of this question. If this is the case, it is possible that talking about positive things, even without actively recognizing that they were grateful for them, benefited parents and children, which is consistent with studies showing that adults and children experience emotional benefits (i.e., sustained positive affect) by sharing positive events (e.g., Gentzler, Morey, Palmer, \& Yi, 2013; Langston, 1994).

\section{Methodological Considerations, Limitations, and Future Directions}

Dose. One methodological issue to consider is that of dose. Parents and children were generally higher in gratitude, relationship satisfaction, and emotional well-being at the beginning of the study, and they may have already been engaging in some gratitude-related practices in daily life, so it is possible that the dosage of the interventions was not strong enough. One dosage issue involves the length of the intervention. Many other gratitude interventions stretch over multiple weeks (ranging from 2 to 10 weeks; Chan, 2010; Emmons \& McCullough, 2003; Lyubomirsky et al., 2005; Rash et al., 2011). Thus, it is possible that the two gratitude interventions would have been more effective if parents and children engaged in them for more than one week. Another dose-related issue is the number of times parents and children engaged in their assigned conversation during the one-week period (i.e., seven days in a row). Other research indicates that gratitude interventions may be more beneficial if the number of times 


\section{PROMOTING PARENTS' AND CHILDREN'S WELL-BEING}

participants are asked to engage in the intervention task is limited. Specifically, a study by Lyubomirsky and colleagues (2005) indicated that gratitude interventions are more beneficial when participants count their blessings once a week over a period of several weeks compared to doing so three times a week over several weeks. They suggested that asking participants to count their blessings too often made them become bored with the activity and made the practice less meaningful and effective, which is in line with the theory of hedonic adaptation where people habituate to good things over time. Thus, in addition to asking parents and children to engage in gratitude practices for more than one week, it may also be more beneficial to ask them to only do this once or twice a week rather than every day. This may especially be important for relational gratitude interventions, where constantly thanking another person may seem insincere or have less impact. A final dosage issue involves the number of things parents and children mentioned each night. In this study, parents and children were only asked to list one thing each during each conversation. However, other gratitude interventions often ask participants to reflect on 3-5 good things (e.g., Emmons \& McCullough, 2003; Seligman et al., 2005). Thus, in addition to spreading parents' and children's conversations out over time, it may also be ideal to ask dyads to talk about several good things during their conversations rather than just one each.

Immediate versus long-term effects. While some research indicates that different types of gratitude interventions have significant immediate effects on participants outcomes (i.e., positive and negative affect; Watkins et al., 2003), other research indicates that counting blessings interventions are most effective over the longer term. Specifically, research by Seligman and colleagues (2005) indicated that participants in a counting blessings intervention did not differ in their levels of happiness from those in an active control immediately postintervention or one week later (similar to this study). However, when happiness was assessed 


\section{PROMOTING PARENTS' AND CHILDREN'S WELL-BEING}

one, three, and six months later, those who had been in the counting blessings condition reported significantly greater happiness than those in the active control, and their happiness was actually highest at the six-month follow-up. In another study by Watkins and colleagues (2015), participants had the greatest increase in subjective well-being at the 5-week follow-up compared to immediately post-treatment and at the 1-week follow-up. These results suggest that gratitude interventions may help people build skills that show the greatest effect when implemented consistently over time, and it is possible that the parents and children in the two gratitude interventions of this study may experience a greater increase in well-being over time compared to those in those in the control group if they have developed skills that they will continue to implement. Future research should examine the longer-term impact of family gratitude interventions on parent and child outcomes.

Experimenter expectancies. Unfortunately, this was not a double-blind study and the experimenter always knew which condition families would be in. Although the experimenter was careful to deliver all intervention instructions in the same way and treat all families equally, unintended experimenter expectancies and impact are still a concern (e.g., Cook \& Campbell, 1979). Future research should use double-blind designs to alleviate this concern.

\section{Conceptual Considerations, Limitations, and Future Directions}

Child understanding and training. It is possible that some children need greater instruction to fully understand gratitude and that parents need to go beyond teaching their children politeness (e.g., saying "thank you"). For example, Froh and colleagues (2014) conducted a successful school-based gratitude curriculum intervention with children ages 8-11, which involved teaching children how to better understand benefactors' intentions, recognize the costs that benefactors incur when providing a kindness, and helping students reflect on the 


\section{PROMOTING PARENTS' AND CHILDREN'S WELL-BEING}

benefits they receive that might make them feel grateful. Lyubomirsky and Layous (2014) have speculated that this type of gratitude intervention may be more beneficial for children than simply having children express gratitude or reflect on things that they are grateful for because this curriculum may help them better engage with the concept. On-going research of parent-child discussion data (including some of the same study participants, $n=28$ ) suggests that there is variation in how much children understand the idea of gratitude (Gentzler \& Ramsey, 2015). Thus, an important next step is translating this gratitude curriculum into a family-based intervention so that parents can better help their children understand the concept of gratitude rather than merely telling their children to say "thank you" to be polite.

Downsides to youth gratitude interventions? A related issue concerns potential downsides to teaching children gratitude through these methods. Specifically, Layous and Lyubormirsky (2014) have suggested that that forcing children to take part in a gratitude intervention when they don't want to may make gratitude expressions and experiences seem obligatory, and that this may hinder children's intrinsic desires or abilities to feel and express genuine gratitude. Carr (2015) has called this "the paradox of gratitude," and it is an important aspect for developmental gratitude researchers to consider moving forward.

Best approach for socializing youth gratitude. Youth gratitude is likely best socialized using multiple approaches, not just one approach (i.e., only counting blessings with children or only expressing gratitude to children). This idea follows suggestions of researchers highlighting that hedonic adaptation may be an issue when only one activity is engaged in consistently, as the effects may wear off over time due to habituation (Lyubomirsky et al., 2005). Additionally, providing people with multiple options allows for better person-activity fit, which is an important factor in ensuring the success of positive psychology interventions (Lyubomirsky \& Layous, 


\section{PROMOTING PARENTS' AND CHILDREN'S WELL-BEING}

2014). Moreover, this idea mirrors other combined positive psychology interventions that involve a number of different activities for people to engage in (e.g., Seligman et al., 2006). Regarding gratitude, parents can do a number of things in addition to practicing a counting blessings habit with their children, expressing gratitude to their children, and encouraging their children to express gratitude. As Froh and Bono (2014) outlined in their new popular press book, parents can model expressions of gratitude by thanking other people (e.g., their spouse), encouraging their children to write thank you notes and take time to reflect on the costs and sacrifices of their benefactor, and generally cultivating a good relationship with their child, in addition to other things. Future research on family gratitude interventions should consider creating conditions that involve more than one method of gratitude socialization.

Generalizability. This study only involved children ages 8-13, so it is unclear how parents might be able to use similar approaches to cultivate gratitude in their adolescents. Furthermore, the sample largely consisted of mothers, so future research should examine if fathers' socialization of gratitude differs, or how two parents or nontraditional caretakers can work together to socialize their children's gratitude. Additionally, this sample was fairly homogenous with respect to race and ethnicity, education, and income, so it is important that similar interventions be tested in more diverse samples. Finally, the comparison of the counting blessings versus relational gratitude interventions was a novel aspect of this study. Future research should examine how these dyadic interventions play out within other close relationships (e.g., friendships, romantic relationships).

\section{Conclusions}

Although gratitude interventions have been successful with adults and children in prior studies (e.g., Seligman et al., 2005; Froh et al., 2008), this study found that two gratitude 


\section{PROMOTING PARENTS' AND CHILDREN'S WELL-BEING}

interventions_ — counting blessings and relational gratitude — had relatively little impact on parents and children, and the impact they did have did not differ from the impact of an active control condition. However, researchers have speculated that youth gratitude interventions could have far-reaching effects due to the many benefits associated with gratitude (e.g, Lyubomirsky \& Layous, 2014), so it is imperative that family gratitude interventions continue to be designed and rigorously tested. Conversely, if family gratitude interventions are consistently less effective than expected, this is important to know, as a significant amount of money is currently being spent on gratitude research (e.g., from the Greater Good Science Center and the John Templeton Foundation) and suggestions on how parents can cultivate their children's gratitude are getting much press time in popular media (e.g., Googling "raising grateful kids" pulls thousands of web articles and books touting a range of advice for parents). This study provides a good starting point for future research to improve on these family gratitude interventions, and a number of possible future directions have been highlighted. 
PROMOTING PARENTS' AND CHILDREN'S WELL-BEING

\section{References}

Adler, M. G., \& Fagley, N. S. (2005). Appreciation: Individual differences in finding value and meaning as a unique predictor of subjective well-being. Journal of Personality, 73(1), 79114.

Algoe, S. B. (2012). Find, remind, and bind: The functions of gratitude in everyday relationships. Social and Personality Psychology Compass, 6(6), 455-469.

Algoe, S. B., Fredrickson, B. L., \& Gable, S. L. (2013). The social functions of the emotion of gratitude via expression. Emotion, 13(4), 605-609.

Algoe, S. B., Gable, S. L., \& Maisel, N. C. (2010). It's the little things: Everyday gratitude as a booster shot for romantic relationships. Personal Relationships, 17(2), 217-233.

Algoe, S. B., \& Haidt, J. (2009).Witnessing excellence in action: The 'other-praising' emotions of elevation, gratitude, and admiration. The Journal of Positive Psychology, 4(2), 105-127.

Algoe, S. B., Haidt, J., \& Gable, S. L. (2008). Beyond reciprocity: gratitude and relationships in everyday life. Emotion, 8(3), 425-429.

Bartlett, M. Y., Condon, P., Cruz, J., Baumann, J., \& Desteno, D. (2012). Gratitude: Prompting behaviours that build relationships. Cognition and Emotion, 26(1), 2-13.

Bauer, D. J., Preacher, K. J., \& Gil, K. M. (2006). Conceptualizing and testing random indirect effects and moderated mediation in multilevel models: new procedures and recommendations. Psychological Methods, 11(2), 142-163.

Baumgarten-Tramer, F. (1938). 'Gratefulness' in children and young people. Journal of Genetic Psychology, 53, 53-66.

Becker, J. A., \& Smenner, P. C. (1986). The spontaneous use of thank you by preschoolers as a function of sex, socioeconomic status, and listener status. Language in Society, 15(4), $537-545$. 


\section{PROMOTING PARENTS' AND CHILDREN'S WELL-BEING}

Boehm, J. K., \& Lyubomirsky, S. (2008). Does happiness lead to career success? Journal of Career Assessment, 16, 101-116.

Bono, G., \& Froh, J. (2009). Gratitude in school: Benefits to students and schools. In R. Gilman, E. Huebner, \& M. J. Furlong (Eds.), Handbook of positive psychology in schools (pp. 7788). New York: Routledge Taylor \& Francis Group.

Brennan, K. A., Clark, C. L., \& Shaver, P. R. (1998). Self-report measurement of adult attachment: An integrative overview. In J. A. Simpson \& W. S. Rholes (Eds.), Attachment theory and close relationships (pp. 46-76). New York: Guilford.

Buhrmester, D. \& Furman, W. (2008). The Network of Relationships Inventory: Relationship Qualities Version. Unpublished measure, University of Texas at Dallas.

Carr, D. (2015). The paradox of gratitude. British Journal of Educational Studies. Advance online publication.

Chan, D. W. (2010). Gratitude, gratitude intervention and subjective well-being among Chinese school teachers in Hong Kong. Educational Psychology, 30(2), 139-153.

Chang, Y. P., Li, T. S., Teng, H. Y., Berki, A., \& Chen, L. H. (2013). Living with gratitude: Spouse's gratitude on one's depression. Journal of Happiness Studies, 14(4), 1431-1442.

Chang, Y., Lin, Y., \& Chen, L. (2012). Pay it forward: Gratitude in social networks. Journal of Happiness Studies, 13(5), 761-781.

Chen, L. H. (2013). Gratitude and adolescent athletes' well-being: The multiple mediating roles of perceived social support from coaches and teammates. Social Indicators Research, $114,273-285$.

Chen, L. H., \& Kee, Y. H. (2008). Gratitude and adolescent athletes' well-being. Social Indicators Research, 89(2), 361-373. 


\section{PROMOTING PARENTS' AND CHILDREN'S WELL-BEING}

Cook, T. D., \& Campbell, D. T. (1979). Quasi-experimentation: Design \& analysis issues for field settings. Chicago: Rand McNally College Publishing Company.

Cook, W. L., \& Kenny, D. A. (2005). The Actor-Partner Interdependence Model: A model of bidirectional effects in developmental studies. International Journal of Behavioral Development, 29(2), 101-109.

Datu, J. A. D. (2014). Forgiveness, gratitude and subjective well-being among Filipino adolescents. International Journal for the Advancement of Counselling, 36(3), 262-273.

DeWall, C. N., Lambert, N. M., Pond, R. S., Kashdan, T. B., \& Fincham, F. D. (2012). A grateful heart is a nonviolent heart: Cross-sectional, experience sampling, longitudinal, and experimental evidence. Social Psychological and Personality Science, 3(2), 232-240.

Diener, E., Emmons, R. A., Larsem, R. J., \& Griffin, S. (1985). The satisfaction with life scale. Journal of Personality Assessment, 49(1), 71-75.

Diener, E., Suh, E. M., Lucas, R. E., \& Smith, H. L. (1999). Subjective well-being: Three decades of progress. Psychological Bulletin, 125(2), 276-302.

Driscoll, K., \& Pianta, R. C. (2011). Mothers' and fathers' perceptions of conflict and closeness in parent-child relationships during early childhood. Journal of Early Childhood and Infant Psychology, 7, 1-24.

Eisenberg, N., Cumberland, A., \& Spinrad, T. L. (1998). Parental socialization of emotion. Psychological Inquiry, 9(4), 241-273.

Emmons, R. A., \& Crumpler, C. A. (2000). Gratitude as a human strength: Appraising the evidence. Journal of Social and Clinical Psychology, 19(1), 56-69. 


\section{PROMOTING PARENTS' AND CHILDREN'S WELL-BEING}

Emmons, R. A. \& McCullough, M. E. (2003). Counting blessings versus burdens: An experimental investigation of gratitude and subjective well-being in daily life. Journal of Personality and Social Psychology, 84(2), 377-389.

Emmons, R. A., \& Mishra, A. (2011). Why gratitude enhances well-being: What we know, what we need to know. In K. M. Sheldon, T. B. Kashdan, \& M. F. Steger (Eds.), Designing positive psychology: Taking stock and moving forward (pp. 248-262). New York: Oxford University Press.

Emmons, R. A., \& Shelton, C. M. (2002). Gratitude and the science of positive psychology. In C. R. Snyder, \& S. J. Lopez (Eds.), Handbook of positive psychology (pp. 459-471). New York: Oxford University Press.

Fredrickson, B. L. (1998a). Cultivated emotions: Parental socialization of positive emotions and self-conscious emotions. Psychological Inquiry, 9(4), 279-281.

Fredrickson, B. L. (1998b). What good are positive emotions? Review of General Psychology, 2(3), 300-319.

Fredrickson, B. L. (2001). The role of positive emotions in positive psychology: The broadenand-build theory of positive emotions. American Psychologist, 56(3), 218-226.

Fredrickson, B. L. (2004). Gratitude, like other positive emotions, broadens and builds. In R. A. Emmons, \& M. E. McCullough (Eds.), The psychology of gratitude (pp. 145-166). New York: Oxford University Press.

Freitas, L., Pieta, M., \& Tudge, J. (2011). Beyond politeness: The expression of gratitude in children and adolescents. Psicologia: Reflexao E Critica, 24(4), 757-764.

Froh, J., \& Bono, G. (2014). Making grateful kids: The science of building character. West Conshohocken, PA: Templeton Foundation Press. 


\section{PROMOTING PARENTS' AND CHILDREN'S WELL-BEING}

Froh, J. J., Bono, G., \& Emmons, R. (2010). Being grateful is beyond good manners: Gratitude and motivation to contribute to society among early adolescents. Motivation and Emotion, 34(2), 144-157.

Froh, J. J., Bono, G., Fan, J., Emmons, R. A., Henderson, K., \& Leggio, H. (2014). Nice thinking! An educational intervention that teaches children how to think gratefully. School Psychology Review, 43(2), 132-152.

Froh, J. J., Emmons, R. A., Card, N. A., Bono, G., \& Wilson, J. (2011a). Gratitude and the reduced costs of materialism in adolescents. Journal of Happiness Studies, 12, 289-302.

Froh, J. J., Fan, J., Emmons, R. A., Bono, G., Huebner, E. S., \& Watkins, P. (2011b). Measuring gratitude in youth: Assessing the psychometric properties of adult gratitude scales in children and adolescents. Psychological Assessment, 23(2), 311.

Froh, J. J., Kashdan, T. B., Ozimkowski, K. M., \& Miller, N. (2009a). Who benefits the most from a gratitude intervention in children and adolescents? Examining positive affect as a moderator. Journal of Positive Psychology, 4(5), 408-422.

Froh, J. J., Miller, D. N., Snyder, S. F. (2007). Gratitude in children and adolescents:

Development, assessment, and school-based intervention. School Psychology Forum, 2(1), 1-13.

Froh, J. J., Sefick, W. J., \& Emmons, R. A. (2008).Counting blessings in early adolescents: An experimental study of gratitude and subjective well-being. Journal of School Psychology, 46, 213-233.

Froh, J. J., Yurkewicz, C., \& Kashdan, T.B. (2009b). Gratitude and subjective well-being in early adolescence: Examining gender differences. Journal of Adolescence, 32, 633-650. 


\section{PROMOTING PARENTS' AND CHILDREN'S WELL-BEING}

Furman, W., \& Buhrmester, D. (2010). Network of relationships questionnaire manual. Unpublished manuscript, University of Denver, Denver, CO, and the University of Texas at Dallas.

Gentzler, A. L., Morey, J. N., Palmer, C. A., \& Yi, C. Y. (2013). Young adolescents' responses to positive events: Associations with positive affect and adjustment. The Journal of Early Adolescence, 33(5), 663-683.

Gentzler, A. L., \& Ramsey, M. A. (2015). [Parent-child discussions about gratitude.] Unpublished raw data.

Gleason, J. B., \& Weintraub, S. (1976). The acquisition of routines in child language. Language in Society, 5(2), 129-136.

Gordon, C. L., Arnette, R. A., \& Smith, R. E. (2011). Have you thanked your spouse today? Felt and expressed gratitude among married couples. Personality and Individual Differences, 50(3), 339-343.

Gordon, A. M., Impett, E. A., Kogan, A., Oveis, C., \& Keltner, D. (2012). To have and to hold: Gratitude promotes relationship maintenance in intimate bonds. Journal of Personality and Social Psychology, 103(2), 257-274.

Gordon, A. K., Musher-Eizenman, D. R., Holub, S. C., \& Dalrymple, J. (2004). What are children thankful for? An archival analysis of gratitude before and after the attacks of September 11. Journal of Applied Developmental Psychology, 25(5), 541-553.

Graham, S. (1988). Children's developing understanding of the motivational role of affect: An attributional analysis. Cognitive Development, 3(1), 71-88. 


\section{PROMOTING PARENTS' AND CHILDREN'S WELL-BEING}

Grant, A. M., \& Gino, F. (2010). A little thanks goes a long way: Explaining why gratitude expressions motivate prosocial behavior. Journal of Personality and Social Psychology, $98(6), 946-955$

Grolnick, W. S., Cosgrove, T. J., \& Bridges, L. J. (1996). Age-graded change in the initiation of positive affect. Infant Behavior and Development, 19(1), 153-157.

Hoy, B. D., Suldo, S. M., \& Mendez, L. R. (2012). Links between parents' and children's levels of gratitude, life satisfaction, and hope. Journal of Happiness Studies, 14(4), 1343-1361.

Huebner, E. S. (1991). Initial development of the Students' Life Satisfaction Scale. School Psychology International, 12, 231-243.

Kaczmarek, L. D., Kashdan, T. B., Drążkowski, D., Bujacz, A., \& Goodman, F. R. (2014). Why do greater curiosity and fewer depressive symptoms predict gratitude intervention use? Utility beliefs, social norm, and self-control beliefs. Personality and Individual Differences, 66, 165-170.

Kaczmarek, L. D., Kashdan, T. B., Kleiman, E. M., Baczkowski, B., Enko, J., Siebers, A., \& ... Baran, B. (2013). Who self-initiates gratitude interventions in daily life? An examination if intentions, curiosity, depressive symptoms, and life satisfaction. Personality and Individual Differences, 55(7), 805-810.

Kashdan, T. B., Mishra, A., Breen, W. E., \& Froh, J. J. (2009). Gender differences in gratitude: Examining appraisals, narratives, the willingness to express emotions, and changes in psychological needs. Journal of Personality, 77(3), 691-730.

Kashdan, T.B., Uswatte, G., \& Julian, T. (2006). Gratitude and hedonic and eudaimonic wellbeing in Vietnam War veterans. Behaviour Research and Therapy, 44, 177-199. 
Kerr, S. L., O’Donovan, A., \& Pepping, C. A. (2015). Can gratitude and kindness interventions enhance well-being in a clinical sample? Journal of Happiness Studies, 16(1), 17-36.

Krause, N. (2006). Gratitude toward God, stress, and health in late life. Research on Aging, $28(2), 163-183$.

Krejtz, I., Nezlek, J. B., Michnicka, A., Holas, P., \& Rusanowska, M. (2014). Counting one’s blessings can reduce the impact of daily stress. Journal of Happiness Studies. Advance online publication.

Krull, J. L., \& MacKinnon, D. P. (1999). Multilevel mediation modeling in group-based intervention studies. Evaluation Review, 23, 418-444.

Kubacka, K. E., Finkenauer, C., Rusbult, C. E., \& Keijsers, L. (2011). Maintaining close relationships: Gratitude as a motivator and a detector of maintenance behavior. Personality and Social Psychology Bulletin, 37(10), 1362-1375.

Kwok, O. M., Underhill, A. T., Berry, J. W., Luo, W., Elliott, T. R., \& Yoon, M. (2008). Analyzing longitudinal data with multilevel models: An example with individuals living with lower extremity intra-articular fractures. Rehabilitation Psychology, 53(3), 370-386.

Lambert, N. M., Clark, M. S., Durtschi, J., Fincham, F. D., \& Graham, S. M. (2010). Benefits of expressing gratitude: Expressing gratitude to a partner changes one's view of the relationship. Psychological Science, 21(4), 574-580.

Lambert, N. M., \& Fincham, F. D. (2011). Expressing gratitude to a partner leads to more relationship maintenance behavior. Emotion, 11(1), 52-60.

Lambert, N. M., Fincham, F. D., \& Stillman, T. F. (2012). Gratitude and depressive symptoms: The role of positive reframing and positive emotion. Cognition and Emotion, 26(4), 615633. 


\section{PROMOTING PARENTS' AND CHILDREN'S WELL-BEING}

Lambert, N. M., Fincham, F. D., Stillman, T. F., \& Dean, L. R. (2009). More gratitude, less materialism: The mediating role of life satisfaction. The Journal of Positive Psychology, $4(1), 32-42$

Lambert, N. M., Graham, S. M., Fincham, F. D., \& Stillman, T. F. (2009). A changed perspective: How gratitude can affect sense of coherence through positive reframing. The Journal of Positive Psychology, 4(6), 461-470.

Langston, C. A. (1994). Capitalizing on and coping with daily-life events: Expressive responses to positive events. Journal of Personality and Social Psychology, 67(6), 1112-1125.

Laurent, J., Cantanzaro, J. S., Thomas, J. E., Rudolph, D. K., Potter, K. I., Lambert, S., et al. (1999). A measure of positive and negative affect for children: Scale development and preliminary validation. Psychological Assessment, 11, 141-169.

Layous, K., \& Lyubomirsky, S. (2014). Benefits, mechanisms, and new directions for teaching gratitude to children. School Psychology Review, 43(2), 153-159.

Lin, C. (2014). A higher-order gratitude uniquely predicts subjective well-being: Incremental validity above the personality and a single gratitude. Social Indicators Research, 119(2), 909-924.

Lyubomirsky, S., Dickerhoof, R., Boehm, J. K., \& Sheldon, K. M. (2011). Becoming happier takes both a will and a proper way: An experimental longitudinal intervention to boost well-being. Emotion, 11, 391-402.

Lyubomirsky, S., \& Layous, K. (2013). How do simple positive activities increase well-being? Current Directions in Psychological Science, 22(1), 57-62.

Lyubomirsky, S., Sheldon, K. M., \& Schkade, D. (2005). Pursuing happiness: The architecture of sustainable change. Review of General Psychology, 9(2), 111-131. 


\section{PROMOTING PARENTS' AND CHILDREN'S WELL-BEING}

Mauss, I. B., Tamir, M., Anderson, C. L., \& Savino, N. S. (2011). Can seeking happiness make people unhappy? Paradoxical effects of valuing happiness. Emotion, 11(4), 807-815.

McCullough, M. E., Emmons, R. A., \& Tsang, J. (2002). The grateful disposition: A conceptual and empirical topography. Journal of Personality and Social Psychology, 82(1), 112-127.

McCullough, M. E., Kilpatrick, S. D., Emmons, R. A., \& Larson, D. B. (2001). Is gratitude a moral affect? Psychological Bulletin, 127(2), 249-266.

McCullough, M. E., Kimeldorf, M. B., \& Cohen, A. D. (2008). An adaptation for altruism: The social causes, social effects, and social evolution of gratitude. Current Directions in Psychological Science, 17(4), 281-285.

McCullough, M. E., Tsang, J., \& Emmons, R. A. (2004). Gratitude in intermediate affective terrain: Links of grateful moods to individual differences and daily emotional experience. Journal of Personality and Social Psychology, 86(2), 295-309.

McNeil, C. B., \& Hembree-Kigin, T. L. (2010). Parent-child interaction therapy. New York: Springer Science \& Business Media.

Murray, A. J., \& Hazelwood, Z. J. (2011). Being grateful: Does it bring us closer? Gratitude, attachment and intimacy in romantic relationships. Journal of Relationships Research, $2(1), 17-25$

Nelson, J. A., Freitas, L. B. D. L., O’Brien, M., Calkins, S. D., Leerkes, E. M., \& Marcovitch, S. (2012). Preschool-aged children's understanding of gratitude: Relations with emotion and mental state knowledge. British Journal of Developmental Psychology, 31(1), 42-56.

Nezlek, J. B. (2008). An introduction to multilevel modeling for social and personality psychology. Social and Personality Psychology Compass, 2(2), 842-860. 


\section{PROMOTING PARENTS' AND CHILDREN'S WELL-BEING}

Nock, M. K., \& Photos, V. (2006). Parent motivation to participate in treatment: Assessment and prediction of subsequent participation. Journal of Child and Family Studies, 15(3), 333346.

Park, N., \& Peterson, C. (2006a). Character strengths and happiness among young children: Content analysis of parental descriptions. Journal of Happiness Studies, 7(3), 323-341.

Park, N., \& Peterson, C. (2006b). Moral competence and character strengths among adolescents: The development and validation of the Values in Action Inventory of Strengths for Youth. Journal of Adolescence, 29(6), 891-909.

Pianta, R. C. (1992). Child-Parent Relationship Scale. Unpublished measure. University of Virginia. Retrieved from http://curry.virginia.edu/uploads/resourceLibrary/CPRSSF_Scoring_Guide.doc

Poelker, K. E., \& Kuebli, J. E. (2014). Does the thought count? Gratitude understanding in elementary school students. The Journal of Genetic Psychology, 175(5), 431-448.

Radloff, L. S. (1977). The CES-D scale: A self-report depression scale for research in the general population. Applied Psychological Measurement, 1(3), 385-401.

Ramsey, M. A., \& Gentzler, A. L. (2015). An upward spiral: Bidirectional associations between positive affect and positive close relationships across the life span. Developmental Review. Advance online publication.

Rash, J. A., Matsuba, M., \& Prkachin, K. M. (2011). Gratitude and well-being: Who benefits the most from gratitude intervention? Applied Psychology: Health and Well-Being, 3(3), 350369.

Russell, J. A., \& Paris, F. A. (1994). Do children acquire concepts for complex emotions abruptly? International Journal of Behavioral Development, 17(2), 349-365. 


\section{PROMOTING PARENTS' AND CHILDREN'S WELL-BEING}

Schaalje, G. B., McBride, J. B., \& Fellingham, G. W. (2001). Approximations to distributions of test statistics in complex mixed linear models using SAS Proc MIXED. SUGI (SAS User's Group International), 262-26, 1-5.

Seligman, M. E., Rashid, T., \& Parks, A. C. (2006). Positive psychotherapy. American Psychologist, 61(8), 774-788.

Seligman, M. P., Steen, T. A., Park, N., \& Peterson, C. (2005). Positive psychology progress: Empirical validation of interventions. American Psychologist, 60(5), 410-421.

Sheldon, K. M., \& Lyubomirsky, S. (2006). How to increase and sustain positive emotion: The effects of expressing gratitude and visualizing best possible selves. The Journal of Positive Psychology, 1(2), 73-82.

Shrive, F. M., Stuart, H., Quan, H., \& Ghali, W. A. (2006). Dealing with missing data in a multiquestion depression scale: A comparison of imputation methods. BMC Medical Research Methodology, 6(57), 1-10.

Simpson, J. A., Collins, W. A., Tran, S., \& Haydon, K. C. (2007). Attachment and the experience and expression of emotions in romantic relationships: A developmental perspective. Journal of Personality and Social Psychology, 92(2), 355-367.

Sin, N. L., \& Lyubomirsky, S. (2009). Enhancing well-being and alleviating depressive symptoms with positive psychology interventions: A practice-friendly meta-analysis. Journal of Clinical Psychology: In Session, 65, 467-487.

Singer, J. D. (1998). Using SAS PROC MIXED to fit multilevel models, hierarchical models, and individual growth models. Journal of Educational and Behavioral Statistics, 23(4), 323-355. 


\section{PROMOTING PARENTS' AND CHILDREN'S WELL-BEING}

Sommers, S., \& Kosmitzki, C. (1988). Emotion and social context: An American-German comparison. British Journal of Social Psychology, 27(1), 35-49.

Toepfer, S. M., Cichy, K., \& Peters, P. (2012). Letters of gratitude: Further evidence for author benefits. Journal of Happiness Studies, 13(1), 187-201.

Toepfer, S. M., \& Walker, K. (2009). Letters of gratitude: Improving well-being through expressive writing. Journal of Writing Research, 1(3), 181-198.

Toussaint, L., \& Friedman, P. (2009). Forgiveness, gratitude, and well-being: The mediating role of affect and beliefs. Journal of Happiness Studies, 10(6), 635-654.

Tsang, J. (2006). Gratitude and prosocial behavior: An experimental test of gratitude. Cognition and Emotion, 20, 138-148.

University of Colorado Denver (2012). GLIMMPSE: General Linear Multivariate Model Power and Sample Size (Version 2.1.0) [Freeware]. Available from http://glimmpse.samplesizeshop.org/\#/

Van Dam, N. T. \& Earleywine, M. (2011). Validation of the Center for Epidemiologic Studies Depression Scale-Revised (CESD-R): Pragmatic depression assessment in the general population. Psychiatry Research, 186, 128-132.

Watkins, P. C. (2014). Gratitude and the good life: Toward a psychology of appreciation. Netherlands: Springer.

Watkins, P. C., Uhder, J., \& Pichinevskiy, S. (2015). Grateful recounting enhances subjective well-being: The importance of grateful processing. The Journal of Positive Psychology, 10(2), 91-98. 


\section{PROMOTING PARENTS' AND CHILDREN'S WELL-BEING}

Watkins, P. C., Woodward, K., Stone, T., \& Kolts, R. L. (2003). Gratitude and happiness:

Development of a measure of gratitude, and relationships with subjective well-being. Social Behavior and Personality, 31, 431-452.

Watson, D., \& Clark, L. A. (1994). The PANAS-X: Manual for the Positive and Negative Affect Schedule - Expanded form. Retrieved on April 13, 2014 from http://www.psychology.uiowa.edu/faculty/watson/PANAS-X.pdf

Watson, D., Clark, L. A., \& Tellegen, A. (1988). Development and validation of brief measures of Positive and Negative Affect: The PANAS scales. Journal of Personality and Social Psychology, 54, 1063-1070.

Weissman, M. M., Orvaschel, H., \& Padian, N. (1980). Children's symptom and social functioning self-report scales: Comparison of mothers' and children's reports. The Journal of Nervous and Mental Disease, 168(12), 736-740.

Wood, A. M., Froh, J. J., \& Geraghty, A. W. (2010). Gratitude and well-being: A review and theoretical integration. Clinical Psychology Review, 30(7), 890-905.

Wood, A. M., Joseph, S., \& Linley, P. (2007). Coping styles as a psychological resource or grateful people. Journal of Social and Clinical Psychology, 26(9), 1076-1093.

Wood, A. M., Joseph, S., \& Maltby, J. (2008a). Gratitude uniquely predicts satisfaction with life: Incremental validity above the domains and facets of the five factor model. Personality and Individual Differences, 45(1), 49-54.

Wood, A. M., Joseph, S., \& Maltby, J. (2009). Gratitude predicts psychological well-being above the Big Five facets. Personality and Individual Differences, 46(4), 443-447. 


\section{PROMOTING PARENTS' AND CHILDREN'S WELL-BEING}

Wood, A. M., Maltby, J., Gillett, R., Linley, P. A., \& Joseph, S. (2008b). The role of gratitude in the development of social support, stress, and depression: Two longitudinal studies.

Journal of Research in Personality, 42(4), 854-871. 


\section{PROMOTING PARENTS' AND CHILDREN'S WELL-BEING}

\section{Footnote}

${ }^{1}$ Based on preliminary coding and the researcher's notes, the conversations of these dyads largely mirrored those of the dyads in the counting blessings group, so analyses were also run with these 9 dyads recoded as being a part of the counting blessings group (new $n=33$ ). Results were consistent for all analyses when the 9 dyads were excluded from analyses and when they were included in the counting blessings group.

${ }^{2}$ When the nine dyads from the control group who discussed gratitude were considered part of the counting blessings group (in line with their conversation topics), there were still no group differences for any demographic characteristics or any of the baseline questionnaires of interest, with the exception of parents' baseline reports of parent-child conflict $(F(2,75)=3.69$, $p=.03)$. Specifically, parents in the counting blessings group reported significantly greater conflict with their children at baseline compared to parents in the control group.

${ }^{3}$ Lagged indirect effects models for parents and children were also conducted for this research question to take full advantage of the daily data. Specifically, daily gratitude on day $\mathrm{n}$ predicted daily relationship satisfaction on day $n+1$, and daily relationship satisfaction on day $\mathrm{n}+1$ predicted daily emotional well-being on day $n+2$. However, the sample was not large enough for either parents or children for the models to converge, and these analyses could not be reported. 
PROMOTING PARENTS' AND CHILDREN'S WELL-BEING

Table 1

Intraclass Correlation Coefficients (ICC) for all Outcomes

\begin{tabular}{|c|c|c|c|c|c|}
\hline \multirow[b]{2}{*}{ Outcome } & \multicolumn{2}{|c|}{$\begin{array}{l}\text { Within-person } \\
\text { variance }\end{array}$} & \multicolumn{2}{|c|}{$\begin{array}{l}\text { Between-person } \\
\text { variance }\end{array}$} & \multirow[b]{2}{*}{ ICC } \\
\hline & $\boldsymbol{\sigma}^{2}$ & $\mathbf{z}$ & $\tau 00$ & $\mathbf{z}$ & \\
\hline Parent Daily Gratitude & 1.79 & $5.61 * * *$ & 1.61 & $17.13 * * *$ & 0.53 \\
\hline Child Daily Gratitude & 3.32 & $5.13 * * *$ & 2.64 & $10.72 * * *$ & 0.56 \\
\hline Parent Daily Relationship Satisfaction & 0.53 & $5.44 * * *$ & 0.61 & $17.13 * * *$ & 0.46 \\
\hline Child Daily Relationship Satisfaction & 1.01 & $5.27 * * *$ & 0.63 & $10.58 * * *$ & 0.61 \\
\hline Parent Daily Emotional Well-being & 2.57 & $5.49 * * *$ & 2.77 & $17.06 * * *$ & 0.48 \\
\hline Child Daily Emotional Well-being & 2.72 & $5.18 * * *$ & 2.06 & $10.70 * * *$ & 0.57 \\
\hline Parent-Report of Conflicts & 0.58 & $5.70 * * *$ & 0.14 & $8.66 * * *$ & 0.80 \\
\hline Parent-Report of Closeness & 0.28 & $5.62 * * *$ & 0.08 & $8.64 * * *$ & 0.78 \\
\hline Parent Depression & 39.83 & $5.21 * * *$ & 21.44 & $8.67 * * *$ & 0.65 \\
\hline Child Depression & 51.87 & $5.36 * * *$ & 22.90 & $8.59 * * *$ & 0.69 \\
\hline
\end{tabular}

Note. ${ }^{* * *} p<.001$. 
PROMOTING PARENTS' AND CHILDREN'S WELL-BEING

Table 2

Correlations between Parents' Reports of Daily Gratitude over Time

\begin{tabular}{|c|c|c|c|c|c|c|c|c|}
\hline & Baseline & Day 1 & Day 2 & Day 3 & Day 4 & Day 5 & Day 6 & Day 7 \\
\hline Baseline & - & & & & & & & \\
\hline Day 1 & $.66 * * *$ & - & & & & & & \\
\hline Day 2 & $.49 * * *$ & $.62 * * *$ & - & & & & & \\
\hline Day 3 & $.48 * * *$ & $.67 * * *$ & $.67 * * *$ & - & & & & \\
\hline Day 4 & $.54 * * *$ & $.61 * * *$ & $.65 * * *$ & $.75 * * *$ & - & & & \\
\hline Day 5 & $.47 * * *$ & $.62 * * *$ & $.64 * * *$ & $.75 * * *$ & $.78 * * *$ & - & & \\
\hline Day 6 & $.45 * * *$ & $.53 * * *$ & $.53 * * *$ & $.51 * * *$ & $.61 * * *$ & $.60 * * *$ & - & \\
\hline Day 7 & $.42 * * *$ & $.52 * * *$ & $.56 * * *$ & $.62 * * *$ & $.66 * * *$ & $.67 * * *$ & $.63 * * *$ & - \\
\hline 1-week & $.33 * *$ & $.55 * * *$ & $.56 * * *$ & $.70 * * *$ & $.55 * * *$ & $.63 * * *$ & $.65 * * *$ & $.61 * * *$ \\
\hline
\end{tabular}


PROMOTING PARENTS' AND CHILDREN'S WELL-BEING

Table 3

Correlations between Parents' Reports of Daily Relationship Satisfaction over Time

\begin{tabular}{|c|c|c|c|c|c|c|c|c|}
\hline & Baseline & Day 1 & Day 2 & Day 3 & Day 4 & Day 5 & Day 6 & Day 7 \\
\hline Baseline & - & & & & & & & \\
\hline Day 1 & $.59 * * *$ & - & & & & & & \\
\hline Day 2 & $.35 * *$ & $.51 * * *$ & - & & & & & \\
\hline Day 3 & $.43 * * *$ & $.51 * * *$ & $.54 * * *$ & - & & & & \\
\hline Day 4 & $.34 * *$ & $.43 * * *$ & $.47 * * *$ & $.53 * * *$ & - & & & \\
\hline Day 5 & .21 & $.29 *$ & $.27 *$ & $.46 * * *$ & $.31 *$ & - & & \\
\hline Day 6 & $.40 * *$ & $.39 * *$ & $.54 * * *$ & $.58 * * *$ & $.59 * * *$ & $.54 * * *$ & - & \\
\hline Day 7 & $.36 * *$ & $.37 * *$ & $.61 * * *$ & $.66 * * *$ & $.47 * * *$ & $.56 * * *$ & $.64 * * *$ & - \\
\hline 1-week & $.30 *$ & $.47 * * *$ & $.57 * * *$ & $.61 * * *$ & $.58 * * *$ & $.43^{* *}$ & $.63 * * *$ & $.60 * * *$ \\
\hline
\end{tabular}


PROMOTING PARENTS' AND CHILDREN'S WELL-BEING

Table 4

Correlations between Parents' Reports of Daily Emotional Well-Being over Time

\begin{tabular}{|c|c|c|c|c|c|c|c|c|}
\hline & Baseline & Day 1 & Day 2 & Day 3 & Day 4 & Day 5 & Day 6 & Day 7 \\
\hline Baseline & - & & & & & & & \\
\hline Day 1 & $.80 * * *$ & - & & & & & & \\
\hline Day 2 & $.53 * * *$ & $.62 * * *$ & - & & & & & \\
\hline Day 3 & $.50 * * *$ & $.65 * * *$ & $.63 * * *$ & - & & & & \\
\hline Day 4 & $.41 * *$ & $.49 * * *$ & $.63 * * *$ & $.75 * * *$ & - & & & \\
\hline Day 5 & $.27 *$ & $.52 * * *$ & $.44 * *$ & $.69 * * *$ & $.60 * * *$ & - & & \\
\hline Day 6 & $.31 *$ & $.46 * * *$ & $.53 * * *$ & $.53 * * *$ & $.48 * * *$ & $.50 * * *$ & - & \\
\hline Day 7 & .17 & $.39 * *$ & $.51 * * *$ & $.44 * *$ & $.43 * * *$ & $.48 * * *$ & $.71 * * *$ & - \\
\hline 1-week & $.49 * * *$ & $.59 * * *$ & $.52 * * *$ & $.60 * * *$ & $.51 * * *$ & $.38 * *$ & $.38 * *$ & $.42 * * *$ \\
\hline
\end{tabular}


PROMOTING PARENTS' AND CHILDREN'S WELL-BEING

Table 5

Correlations between Children's Reports of Daily Gratitude over Time

\begin{tabular}{lccc}
\hline & Baseline & Day 1 & Day 2 \\
\hline Baseline & - & & \\
Day 3 & $.61 * * *$ & - & \\
Day 7 & $.45 * * *$ & $.68 * * *$ & - \\
1-week & $.47 * * *$ & $.67 * * *$ & $.69 * * *$ \\
\hline Note $* * * p<$ & & &
\end{tabular}

Note. $* * * p .001$. 
PROMOTING PARENTS' AND CHILDREN'S WELL-BEING

Table 6

Correlations between Children's Reports of Daily Relationship Satisfaction over Time

\begin{tabular}{lccc}
\hline & Baseline & Day 1 & Day 2 \\
\hline Baseline & - & & \\
Day 3 & $.35 * * *$ & & \\
Day 7 & $.52 * * *$ & $.63 * * *$ & \\
1 -week & $.59 * * *$ & $.64 * * *$ & $.62 * * *$ \\
\hline Note. ${ }^{* * *} p<.001$. & &
\end{tabular}


PROMOTING PARENTS' AND CHILDREN'S WELL-BEING

Table 7

Correlations between Children's Reports of Daily Emotional Well-Being over Time

\begin{tabular}{lccc}
\hline & Baseline & Day 1 & Day 2 \\
\hline Baseline & - & & \\
Day 3 & $.65 * * *$ & & \\
Day 7 & $.52 * * *$ & $.71 * * *$ & \\
1 -week & $.53 * * *$ & $.66 * * *$ & $.58 * * *$ \\
\hline Note. ${ }^{* * *} p<.001$. & &
\end{tabular}


PROMOTING PARENTS' AND CHILDREN'S WELL-BEING

Table 8

Group Comparisons: Demographic Characteristics and Baseline Scores of Interest

\begin{tabular}{lccc}
\hline & $\begin{array}{c}\text { Relational Gratitude } \\
(\boldsymbol{n}=\mathbf{2 6})\end{array}$ & $\begin{array}{c}\text { Counting Blessings } \\
(\boldsymbol{n}=\mathbf{2 4})\end{array}$ & $\begin{array}{c}\text { Control } \\
(\boldsymbol{n}=\mathbf{1 9})\end{array}$ \\
\hline Parent Age & $39.12(7.22)$ & $41.00(6.50)$ & $38.58(8.59)$ \\
Parent Gender & $100 \%$ Female & $92 \%$ Female & $100 \%$ Female \\
Parent Race/Ethnicity & $89 \%$ Caucasian & $89 \%$ Caucasian & $90 \%$ Caucasian \\
Parent Education & Associate/Bachelors & Associate/Bachelors & Associate/Bachelors \\
Household Income & $\$ 60,000-\$ 69,999$ & $\$ 60,000-\$ 69,999$ & $\$ 60,000-\$ 69,999$ \\
Child Age & $10.57(1.64)$ & $10.37(1.35)$ & $9.93(1.69)$ \\
Child Gender & $50 \%$ Female & $63 \%$ Female & $58 \%$ Female \\
Child Race/Ethnicity & $73 \%$ Caucasian & $88 \%$ Caucasian & $74 \%$ Caucasian \\
Parent Trait Gratitude & $5.99(.90)$ & $6.37(.62)$ & $6.35(.56)$ \\
Child Trait Gratitude & $6.13(.83)$ & $6.02(.76)$ & $6.14(.89)$ \\
Parent Emotional WB & $-.94(2.69)$ & $-.29(2.07)$ & $-.11(2.05)$ \\
Child Emotional WB & $-.01(2.10)$ & $-.42(2.55)$ & $.22(1.33)$ \\
Parent Motivation & $5.53(.45)$ & $5.61(.56)$ & $5.75(.27)$ \\
Parent Depression & $8.62(8.07)$ & $7.33(6.64)$ & $8.42(9.07)$ \\
Child Depression & $10.23(8.12)$ & $10.08(7.99)$ & $10.31(7.23)$ \\
Parent-Child Closeness & $4.23(.60)$ & $4.24(.61)$ & $4.38(.55)$ \\
Parent-Child Conflicts & $2.04(.93)$ & $2.39(.90)$ & $1.88(.75)$ \\
\hline
\end{tabular}

Note. Means (and standard deviations when appropriate) are reported unless percentages are indicated. $\mathrm{WB}=$ well-being. Closeness and conflicts were parent-report. 
PROMOTING PARENTS' AND CHILDREN'S WELL-BEING

Table 9

Group Comparisons of Daily Gratitude across the Study

\begin{tabular}{lccc}
\hline & $\begin{array}{c}\text { Relational Gratitude } \\
(\boldsymbol{n}=\mathbf{2 6})\end{array}$ & $\begin{array}{c}\text { Counting Blessings } \\
(\boldsymbol{n}=\mathbf{2 4})\end{array}$ & $\begin{array}{c}\text { Control } \\
(\boldsymbol{n}=\mathbf{1 9})\end{array}$ \\
\hline $\begin{array}{c}\text { Parent Gratitude } \\
\text { Baseline }\end{array}$ & $6.11(2.20)$ & $6.78(2.13)$ & $7.32(1.68)$ \\
Day 1 & $7.04(1.53)$ & $7.41(1.36)$ & $7.93(1.25)$ \\
Day 2 & $7.00(2.08)$ & $7.70(1.55)$ & $8.23(1.32)$ \\
Day 3 & $6.75(2.19)$ & $7.68(1.90)$ & $7.88(1.94)$ \\
Day 4 & $6.88(1.98)$ & $7.10(1.63)$ & $7.93(1.81)$ \\
Day 5 & $6.58(2.30)$ & $7.23(1.87)$ & $7.85(1.48)$ \\
Day 6 & $6.92(1.82)$ & $7.10(2.13)$ & $8.33(1.15)$ \\
Day 7 & $7.35(1.86)$ & $7.59(1.78)$ & $7.81(1.79)$ \\
Follow-up & $7.12(1.86)$ & $7.33(1.78)$ & $7.98(1.64)$ \\
Child Gratitude & & & \\
Baseline & $5.87(2.48)$ & $5.83(2.25)$ & $6.12(2.39)$ \\
Day 3 & $7.01(2.23)$ & $6.93(2.30)$ & $6.98(2.57)$ \\
Day 7 & $6.63(2.61)$ & $6.77(2.13)$ & $6.98(3.10)$ \\
Follow-up & $6.45(2.77)$ & $7.13(2.18)$ & $7.02(2.45)$ \\
\hline Note. Means (and $)$
\end{tabular}

Note. Means (and standard deviations) are reported. 
PROMOTING PARENTS' AND CHILDREN'S WELL-BEING

Table 10

Group Comparisons of Daily Relationship Satisfaction across the Study

\begin{tabular}{lccc}
\hline & $\begin{array}{c}\text { Relational Gratitude } \\
(\boldsymbol{n}=\mathbf{2 6})\end{array}$ & $\begin{array}{c}\text { Counting Blessings } \\
(\boldsymbol{n}=\mathbf{2 4})\end{array}$ & $\begin{array}{c}\text { Control } \\
(\boldsymbol{n}=\mathbf{1 9})\end{array}$ \\
\hline $\begin{array}{c}\text { Parent Rel. Satisfaction } \\
\text { Baseline }\end{array}$ & $6.50(1.28)$ & $6.30(.95)$ & $6.65(.97)$ \\
Day 1 & $6.74(.82)$ & $6.87(.80)$ & $6.88(.88)$ \\
Day 2 & $6.76(.99)$ & $6.42(.97)$ & $6.93(.63)$ \\
Day 3 & $6.29(1.29)$ & $6.85(.94)$ & $6.86(1.15)$ \\
Day 4 & $6.47(.99)$ & $6.63(.97)$ & $7.16(.88)$ \\
Day 5 & $6.80(1.05)$ & $7.00(.87)$ & $6.72(.94)$ \\
Day 6 & $6.83(1.02)$ & $6.52(1.18)$ & $7.08(1.06)$ \\
Day 7 & $6.86(1.00)$ & $6.68(.88)$ & $7.17(.74)$ \\
Follow-up & $6.72(1.03)$ & $6.62(1.38)$ & $7.33(.70)$ \\
Child Rel. Satisfaction & & & \\
Baseline & $7.08(1.14)$ & $7.06(1.21)$ & $6.86(1.28)$ \\
Day 3 & $7.19(1.01)$ & $6.88(1.20)$ & $7.30(1.12)$ \\
Day 7 & $6.90(1.17)$ & $6.97(1.25)$ & $7.03(1.20)$ \\
Follow-up & $7.12(1.12)$ & $6.72(1.23)$ & $6.94(1.27)$ \\
\hline Note. Means (and $)$
\end{tabular}

Note. Means (and standard deviations) are reported. 
PROMOTING PARENTS' AND CHILDREN'S WELL-BEING

Table 11

Group Comparisons of Daily Emotional Well-Being across the Study

\begin{tabular}{lccc}
\hline & $\begin{array}{c}\text { Relational Gratitude } \\
(\boldsymbol{n}=\mathbf{2 6})\end{array}$ & $\begin{array}{c}\text { Counting Blessings } \\
(\boldsymbol{n}=\mathbf{2 4})\end{array}$ & $\begin{array}{c}\text { Control } \\
(\boldsymbol{n}=\mathbf{1 9})\end{array}$ \\
\hline $\begin{array}{l}\text { Parent Emotional WB } \\
\text { Baseline }\end{array}$ & $-.97(2.26)$ & $.13(1.61)$ & $-.12(2.20)$ \\
Day 1 & $-.45(2.39)$ & $.67(1.79)$ & $.47(2.02)$ \\
Day 2 & $-.35(2.22)$ & $.19(1.85)$ & $.94(1.56)$ \\
Day 3 & $-.77(3.06)$ & $-.03(2.33)$ & $1.14(1.99)$ \\
Day 4 & $-.46(2.69)$ & $-.19(2.44)$ & $1.17(1.75)$ \\
Day 5 & $-.58(2.56)$ & $.05(2.46)$ & $.55(1.42)$ \\
Day 6 & $-.38(2.36)$ & $-.54(2.93)$ & $.94(1.55)$ \\
Day 7 & $.19(1.89)$ & $-.04(2.54)$ & $1.33(1.55)$ \\
Follow-up & $-.25(2.84)$ & $-.42(2.45)$ & $.79(2.24)$ \\
Child Emotional WB & & & $.51(1.31)$ \\
Baseline & $-.01(2.00)$ & $-.15(2.16)$ & $.39(1.98)$ \\
Day 3 & $.23(2.13)$ & $.09(2.49)$ & $.58(1.88)$ \\
Day 7 & $-.10(2.43)$ & $.28(2.07)$ & $.21(2.22)$ \\
Follow-up & $-.64(2.95)$ & $.01(2.04)$ & \\
\hline Note. Means (and
\end{tabular}

Note. Means (and standard deviations) are reported. 
PROMOTING PARENTS' AND CHILDREN'S WELL-BEING

Table 12

Correlations between Baseline Trait and Demographic Variables of Interest

\begin{tabular}{|c|c|c|c|c|c|c|c|c|c|c|c|c|}
\hline & 1 & 2 & 3 & 4 & 5 & 6 & 7 & 8 & 9 & 10 & 11 & 12 \\
\hline 1. P. Motivation & - & & & & & & & & & & & \\
\hline 2. P. Gratitude & $.27 *$ & - & & & & & & & & & & \\
\hline 3. C. Gratitude & -.01 & .11 & - & & & & & & & & & \\
\hline 4. P. Well-Being & $.25^{*}$ & $.57 * * *$ & .01 & - & & & & & & & & \\
\hline 5. C. Well-Being & -.04 & -.16 & $.49 * * *$ & -.03 & - & & & & & & & \\
\hline 6. P.-C. Conflicts & $-.34 * *$ & $-.25 *$ & -.05 & $-.49 * * *$ & -.09 & - & & & & & & \\
\hline 7. P.-C. Closeness & $.25^{*}$ & .15 & -.05 & $.32 * *$ & -.03 & $-.60 * * *$ & - & & & & & \\
\hline 8. P. Depression & -.15 & $-.36^{* *}$ & .04 & $-.69 * * *$ & .07 & $.43 * * *$ & $-.21^{+}$ & - & & & & \\
\hline 9. C. Depression & -.07 & .18 & $-.39 * *$ & .11 & $-.60 * * *$ & .07 & -.02 & -.05 & - & & & \\
\hline 10. P. Age & $-.22^{+}$ & .06 & -.04 & -.04 & -.05 & .06 & -.05 & .09 & -.02 & - & & \\
\hline 11. C. Age & -.05 & .06 & .09 & -.08 & -.18 & $.21^{+}$ & $-.37 * *$ & .03 & .03 & $.21^{+}$ & - & \\
\hline 12. Income & .07 & $.22^{+}$ & .04 & .16 & .08 & $-.23^{+}$ & .13 & -.09 & $-.24^{+}$ & $.33 * *$ & .02 & - \\
\hline 13. P. Education & -.05 & .12 & .04 & -.01 & -.01 & -.18 & .02 & -.08 & $-.21^{+}$ & $.36 * *$ & -.04 & $.72 * * *$ \\
\hline
\end{tabular}

Note. $\mathrm{P}=$ parent. $\mathrm{C}=$ child. ${ }^{+} p<.085 .{ }^{*} p<.05 . * * p<.01 .{ }^{* * *} p<.001$. 
PROMOTING PARENTS' AND CHILDREN'S WELL-BEING

Table 13

Multilevel Modeling: Daily Level 1 Variables Predicting Each Other for Parents and Children

\begin{tabular}{|c|c|c|c|c|c|c|c|}
\hline Predictor Variable & Predicted Variable & Slope $B$ & Slope $S E$ & Slope $p$ & Intercept $B$ & Intercept $S E$ & Intercept $p$ \\
\hline \multicolumn{8}{|l|}{ Parents } \\
\hline Daily Gratitude & $\begin{array}{l}\text { Daily Relationship } \\
\text { Satisfaction }\end{array}$ & .20 & .02 & $<.001$ & 5.28 & .19 & $<.001$ \\
\hline $\begin{array}{l}\text { Daily Relationship } \\
\text { Satisfaction }\end{array}$ & $\begin{array}{l}\text { Daily Emotional } \\
\text { Well-Being }\end{array}$ & .67 & .09 & $<.001$ & -4.48 & .61 & $<.001$ \\
\hline Daily Gratitude & $\begin{array}{l}\text { Daily Emotional } \\
\text { Well-Being }\end{array}$ & .69 & .05 & $<.001$ & -5.01 & .38 & $<.001$ \\
\hline $\begin{array}{l}\text { Daily Gratitude } \\
\text { (accounting for Rel. Sat.) }\end{array}$ & $\begin{array}{l}\text { Daily Emotional } \\
\text { Well-Being }\end{array}$ & .63 & .05 & $<.001$ & -6.61 & .57 & $<.001$ \\
\hline \multicolumn{8}{|l|}{ Children } \\
\hline Daily Gratitude & $\begin{array}{l}\text { Daily Relationship } \\
\text { Satisfaction }\end{array}$ & .17 & .03 & $<.001$ & 5.84 & .21 & $<.001$ \\
\hline $\begin{array}{l}\text { Daily Relationship } \\
\text { Satisfaction }\end{array}$ & $\begin{array}{l}\text { Daily Emotional } \\
\text { Well-Being }\end{array}$ & .59 & .11 & $<.001$ & -4.10 & .77 & $<.001$ \\
\hline Daily Gratitude & $\begin{array}{l}\text { Daily Emotional } \\
\text { Well-Being }\end{array}$ & .32 & .05 & $<.001$ & -2.04 & .38 & $<.001$ \\
\hline $\begin{array}{l}\text { Daily Gratitude } \\
\text { (accounting for Rel. Sat.) }\end{array}$ & $\begin{array}{l}\text { Daily Emotional } \\
\text { Well-Being }\end{array}$ & .26 & .05 & $<.001$ & -4.59 & .75 & $<.001$ \\
\hline
\end{tabular}


PROMOTING PARENTS'AND CHILDREN'S WELL-BEING

Table 14

Actor-Partner Independence Models

\begin{tabular}{lccccc}
\hline & $\begin{array}{c}\text { Daily Gratitude } \\
\text { (Stability- } \\
\text { Influence) }\end{array}$ & $\begin{array}{c}\text { Daily Relationship } \\
\text { Satisfaction } \\
\text { (Stability- } \\
\text { Influence) }\end{array}$ & $\begin{array}{c}\text { Daily Emotional } \\
\text { Well-Being } \\
\text { (Stability- } \\
\text { Influence) }\end{array}$ & $\begin{array}{c}\text { Daily Gratitude } \rightarrow \\
\text { Daily Relationship } \\
\text { Satisfaction }\end{array}$ & $\begin{array}{c}\text { Daily Gratitude } \rightarrow \\
\text { Daily Emotional } \\
\text { Well-Being }\end{array}$ \\
\cline { 2 - 7 } Parent $\rightarrow$ Parent & $B(S E)$ & $B(S E)$ & $B(S E)$ & $B(S E)$ & $B(S E)$ \\
Child $\rightarrow$ Child & $.51(.05)^{* * *}$ & $.40(.06)^{* * *}$ & $.55(.06)^{* * *}$ & $.10(.03)^{* *}$ & $.28(.08)^{* * *}$ \\
Parent $\rightarrow$ Child & $.68(.09)^{* * *}$ & $.59(.10)^{* * *}$ & $.79(.15)^{* * *}$ & $.21(.05) * * *$ & $.39(.11)^{* *}$ \\
Child $\rightarrow$ Parent & $.02(.04)$ & $.05(.06)$ & $-.03(.08)$ & $.03(.03)$ & $.11(.07)$ \\
\hline
\end{tabular}

Note. ${ }^{* *} p=.01 . * * * p<.001$. 
PROMOTING PARENTS' AND CHILDREN'S WELL-BEING

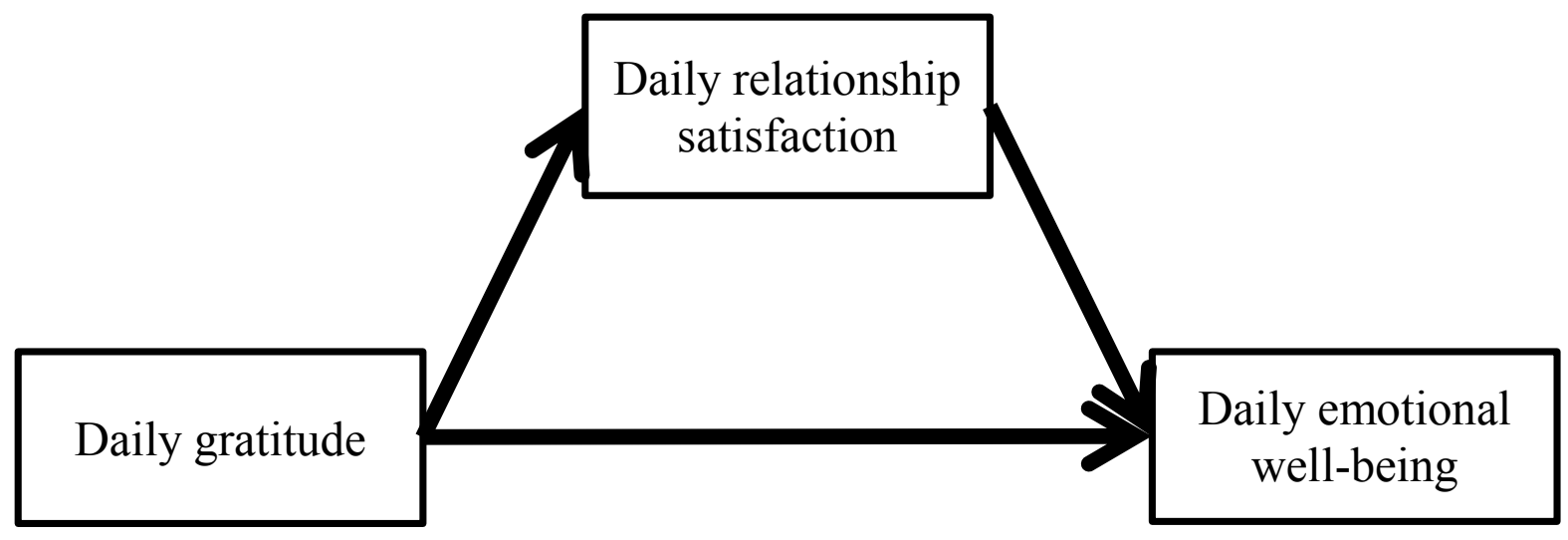

Figure 1. Hypothesized model for research question and hypothesis 2. 


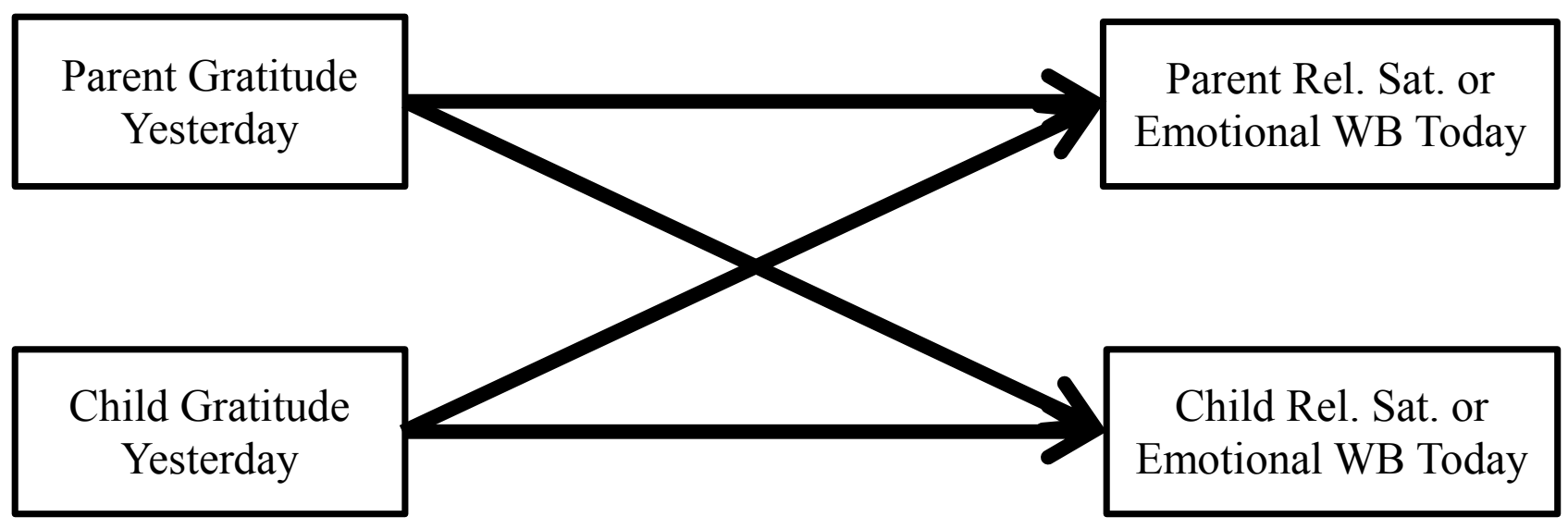

Figure 2. Conceptual model for research question 4 and hypotheses $4 \mathrm{a}$ and $4 \mathrm{~b}$. 
PROMOTING PARENTS' AND CHILDREN'S WELL-BEING

\begin{tabular}{|c|c|c|c|c|c|c|c|c|c|}
\hline Day & 0 & 1 & 2 & 3 & 4 & 5 & 6 & 7 & 14 \\
\hline Task & $\begin{array}{l}\text { Initial } \\
\text { In-person } \\
\text { Session }\end{array}$ & $\begin{array}{l}\text { First day of } \\
\text { Week-long } \\
\text { Session } \\
\text { (same day } \\
\text { as in-person } \\
\text { session) }\end{array}$ & $\begin{array}{l}\text { Second day } \\
\text { of Week- } \\
\text { long } \\
\text { Session }\end{array}$ & $\begin{array}{l}\text { Third day of } \\
\text { Week-long } \\
\text { Session }\end{array}$ & $\begin{array}{l}\text { Fourth day } \\
\text { of Week- } \\
\text { long } \\
\text { Session }\end{array}$ & $\begin{array}{l}\text { Fifth day of } \\
\text { Week-long } \\
\text { Session }\end{array}$ & $\begin{array}{l}\text { Sixth day of } \\
\text { Week-long } \\
\text { Session }\end{array}$ & $\begin{array}{l}\text { Seventh day } \\
\text { of Week- } \\
\text { long } \\
\text { Session }\end{array}$ & $\begin{array}{l}\text { One week } \\
\text { Follow-up }\end{array}$ \\
\hline Procedure & $\begin{array}{l}\begin{array}{l}\text { Surveys in } \\
\text { person }\end{array} \\
\text { Received } \\
\text { week-long } \\
\text { and follow- } \\
\text { up instruct- } \\
\text { ions }\end{array}$ & $\begin{array}{l}\text { Engaged in } \\
\text { daily task } \\
\text {-------- } \\
\text { Parent } \\
\text { Online }\end{array}$ & $\begin{array}{l}\text { Engaged in } \\
\text { daily task } \\
- \text { Parent } \\
\text { Online }\end{array}$ & $\begin{array}{l}\begin{array}{l}\text { Engaged in } \\
\text { daily task }\end{array} \\
- \text { Parent } \\
\text { Online } \\
\text {------- } \\
\text { Called } \\
\text { Child }\end{array}$ & $\begin{array}{l}\begin{array}{l}\text { Engaged in } \\
\text { daily task }\end{array} \\
-------- \\
\text { Parent } \\
\text { Online }\end{array}$ & $\begin{array}{l}\begin{array}{l}\text { Engaged in } \\
\text { daily task }\end{array} \\
\text {-------- } \\
\text { Parent } \\
\text { Online }\end{array}$ & $\begin{array}{l}\begin{array}{l}\text { Engaged in } \\
\text { daily task }\end{array} \\
------- \\
\text { Parent } \\
\text { Online }\end{array}$ & $\begin{array}{l}\begin{array}{l}\text { Engaged in } \\
\text { daily task }\end{array} \\
- \text { Parent } \\
\text { Online } \\
\text {------- } \\
\text { Called } \\
\text { Child }\end{array}$ & $\begin{array}{l}\text { Parent } \\
\text { Online } \\
\text {-------- } \\
\text { Called } \\
\text { Child }\end{array}$ \\
\hline
\end{tabular}

Figure 3. Study procedure timeline. 

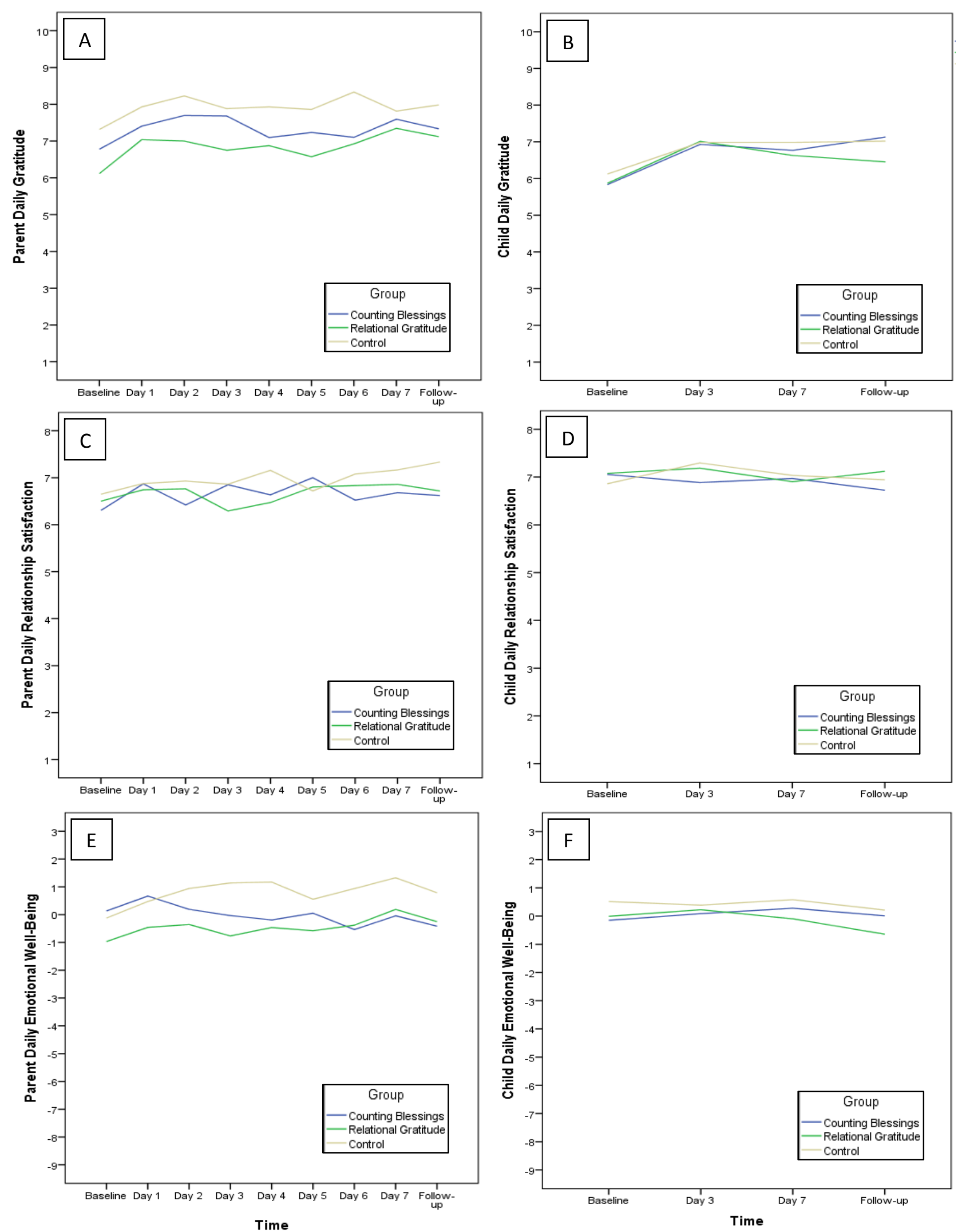

Figure 4. Changes in parent and child daily outcomes using survey as a proxy for time. 
PROMOTING PARENTS' AND CHILDREN'S WELL-BEING

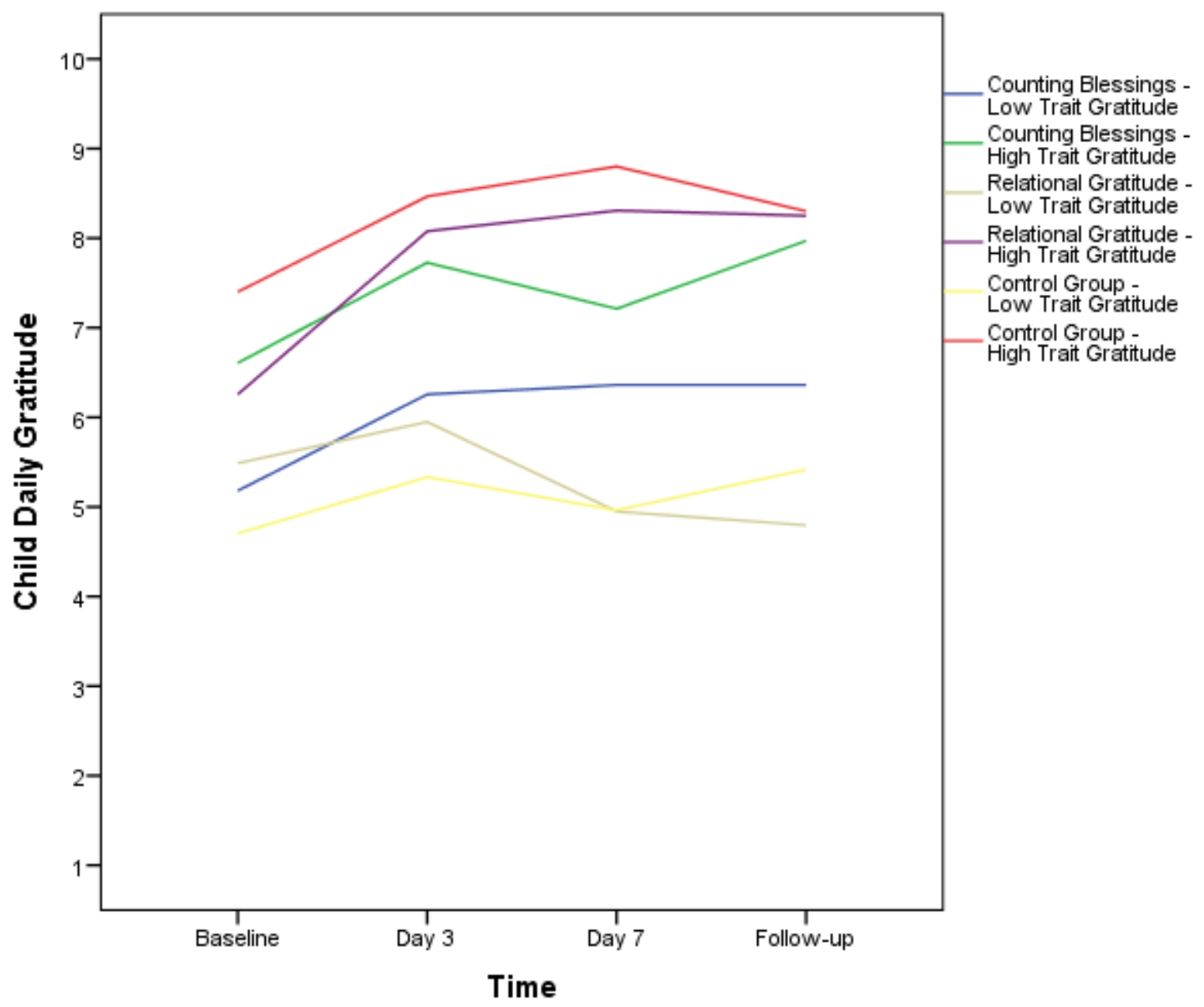

Figure 5. Three-way interaction (child baseline trait gratitude $\mathrm{X}$ group $\mathrm{X}$ time) for child daily gratitude. 
PROMOTING PARENTS' AND CHILDREN'S WELL-BEING

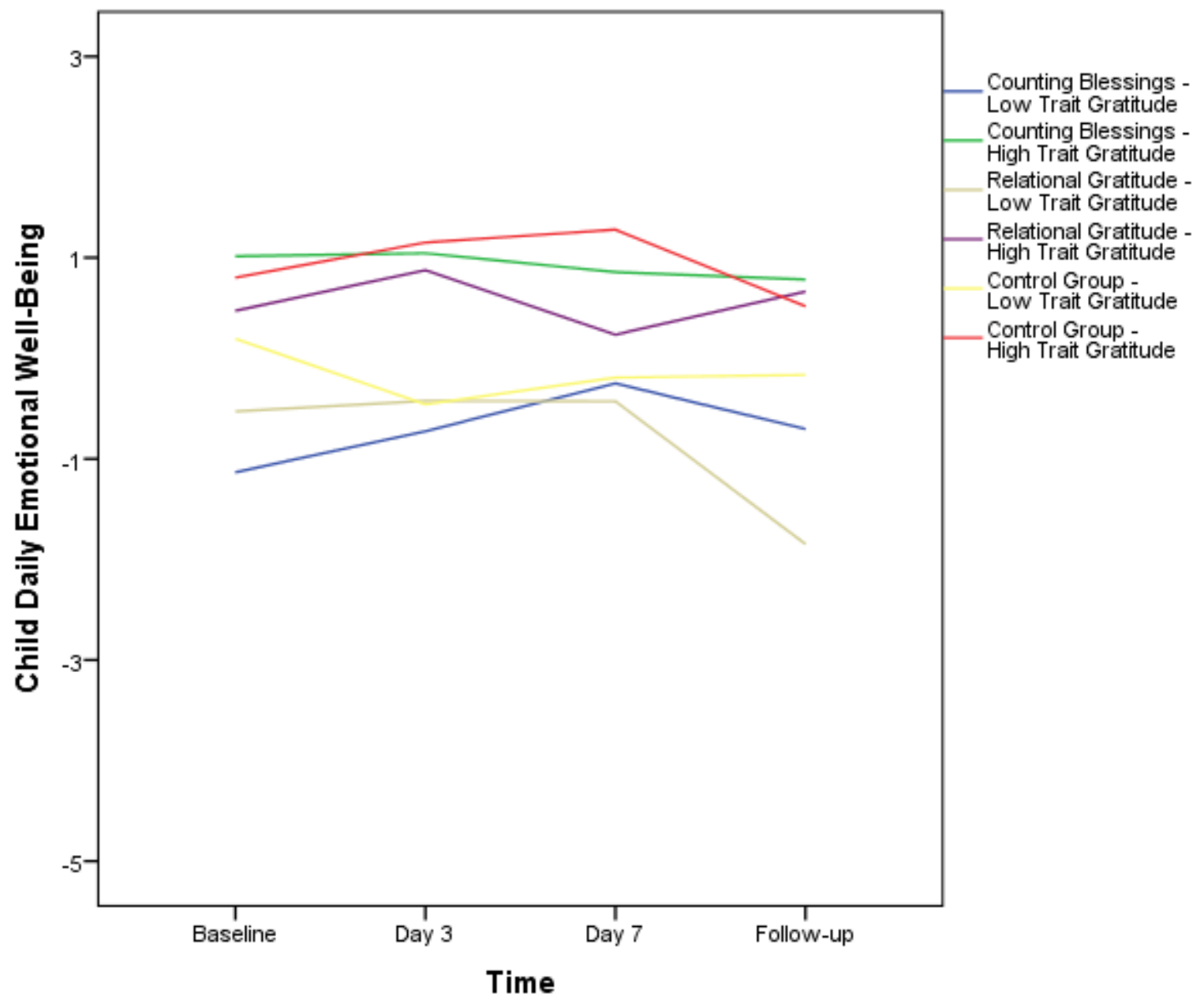

Figure 6. Three-way interaction (child baseline trait gratitude $\mathrm{X}$ group $\mathrm{X}$ time) for child daily emotional well-being. 


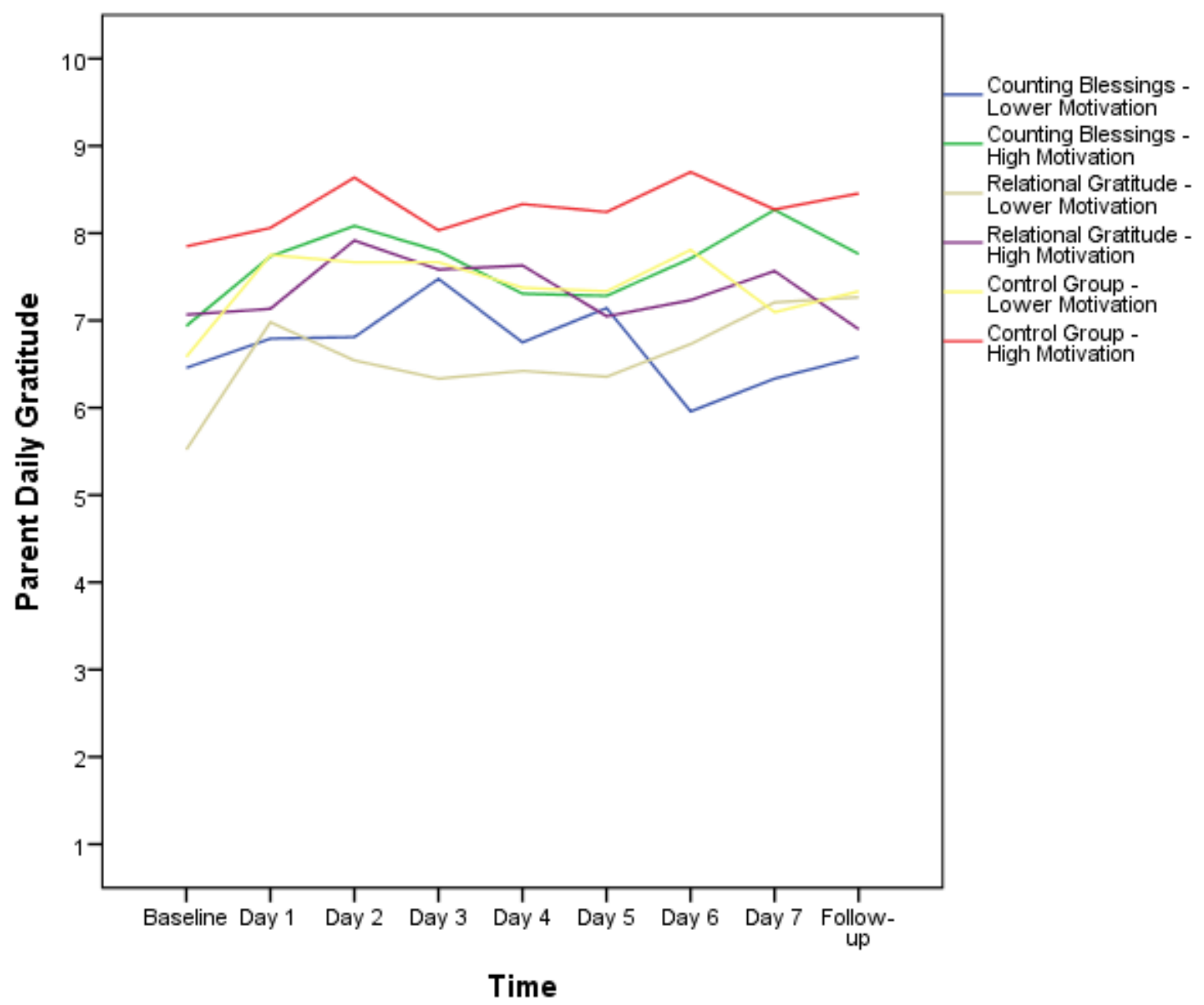

Figure 7. Three-way interaction (parent motivation $\mathrm{X}$ group $\mathrm{X}$ time) for parent daily gratitude. 
PROMOTING PARENTS' AND CHILDREN'S WELL-BEING
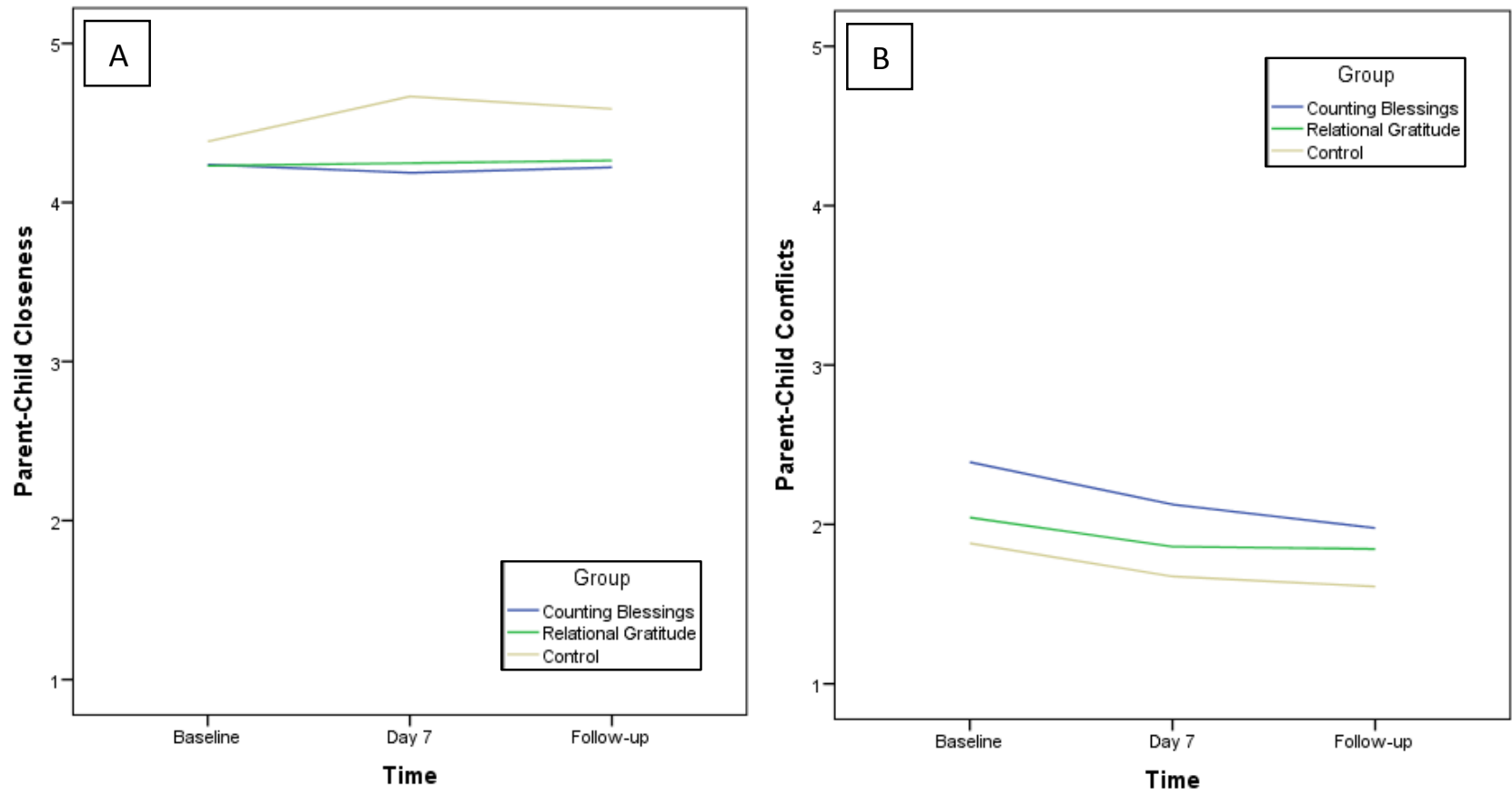

Figure 8. Changes in parent-report of parent-child closeness and conflicts using survey as a proxy for time. 
PROMOTING PARENTS’ AND CHILDREN'S WELL-BEING
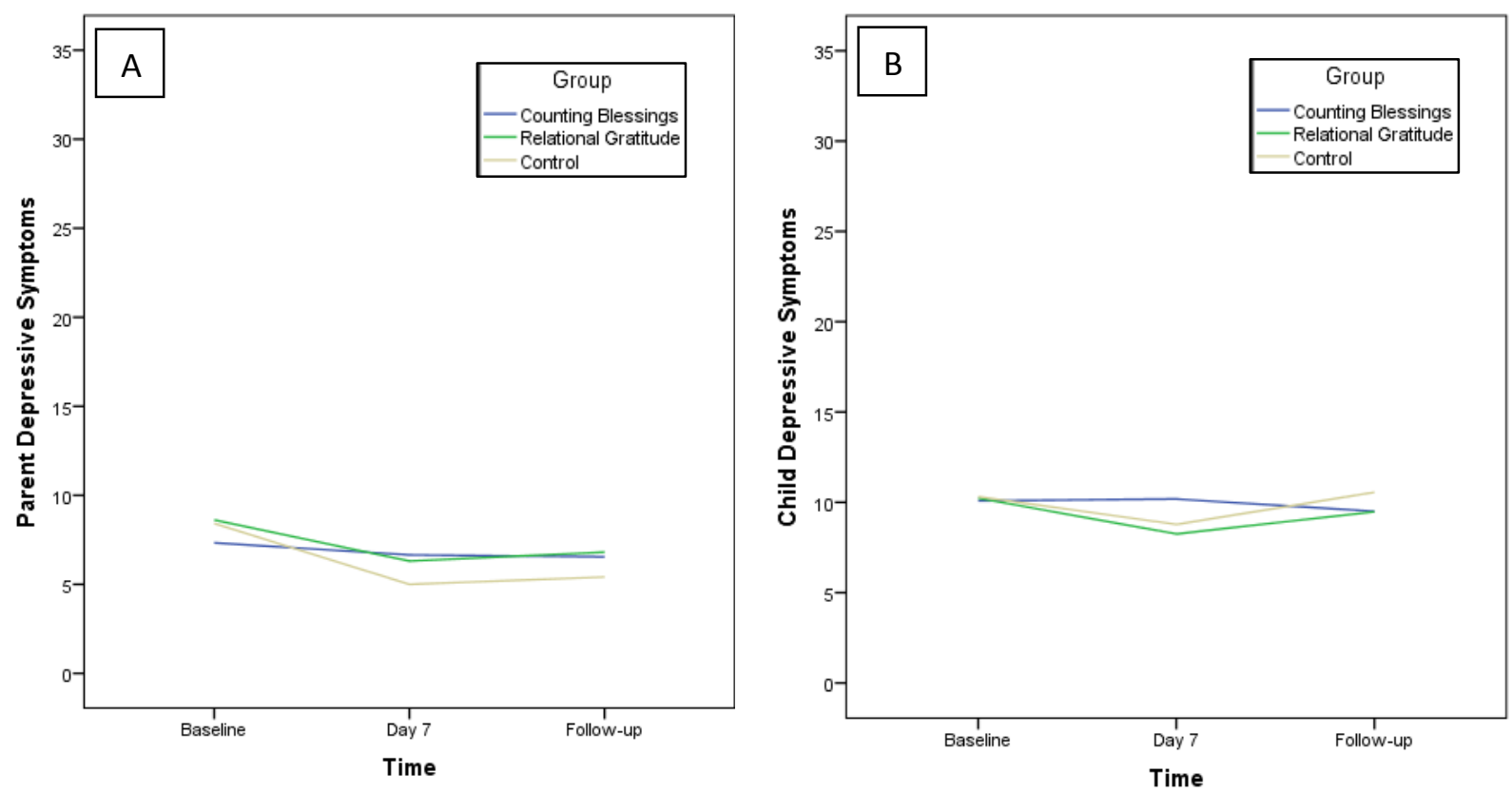

Figure 9. Changes in parent and child depressive symptoms using survey as a proxy for time. 


\section{PROMOTING PARENTS' AND CHILDREN'S WELL-BEING}

\section{Appendix A}

\section{Relational Gratitude Condition Instructions}

"This is a study to increase your gratitude. Gratitude means being thankful, or noticing and appreciating the good things in life. Each night for the next week, we want you to have a short conversation at bedtime that will help you be more grateful. Research shows that expressing your thankfulness to each other can help you be more grateful, so here is your conversation topic: There are many things you do for each other, both big and small, that you might be thankful for. Each evening, you and your child should both share something good that you are thankful for that the other has done. In other words, you will thank your child for something they have done and your child will thank you for something you have done. You can choose to thank each other for something big or small, as long as it is something good the other did that you are actually thankful for. Examples might be the child being thankful for the parent cooking them dinner, or the parent being thankful for the child cleaning up their room. You should also talk about why these good things happened. In other words, what did the other person have to do or give up for the good thing you are thankful for to occur? You should both come up with something new each night—do not repeat the same thing each night. You should do this once each night for seven nights in a row, starting tonight, and you should try to talk for at least three minutes each night." 


\section{PROMOTING PARENTS' AND CHILDREN'S WELL-BEING}

\section{Appendix B}

\section{Counting Blessings Condition Instructions}

"This is a study to increase your gratitude. Gratitude means being thankful, or noticing and appreciating the good things in life. Each night for the next week, we want you to have a short conversation at bedtime that will help you be more grateful. Research shows that counting your blessings together can help you be more grateful, so here is your conversation topic: There are many things in life, both big and small, that you might be thankful for. Each evening, you and your child should both share something good that you are thankful for. In other words, you will share something you are thankful for and your child will share something they are thankful for. You can choose to share something big or small, as long as it is something good that you are actually thankful for. Examples might be the child being thankful for getting a good grade in school, or the parent being thankful for having a day off work. You should also talk about why these good things happened. In other words, what was the cause of the good thing you are thankful for, or what had to occur for it to happen? You should both come up with something new each night—do not repeat the same thing each night. You should do this once each night for seven nights in a row, starting tonight, and you should try to talk for at least three minutes each night." 


\section{PROMOTING PARENTS' AND CHILDREN'S WELL-BEING}

\section{Appendix C}

\section{Control Condition Instructions}

"This is a study to increase your gratitude. Gratitude means being thankful, or noticing and appreciating the good things in life. Each night for the next week, we want you to have a short conversation at bedtime that will help you be more grateful. Research shows that simply spending time together can help you be more grateful, so here is your conversation topic: There are many things in life, both big and small, that you might notice throughout your day. Each evening, you and your child should both share something from your day. In other words, you will share something from your day and your child will share something from their day. You can choose to share something big or small, as long as it is something you actually noticed or thought about that day. Examples might be the child talking about something that happened while playing with a friend, or the parent talking about something they did at work. You should also talk about why these things happened. In other words, what was the cause of the thing you noticed, or what had to occur for it to happen? You should both come up with something NEW each night—do NOT repeat the same thing each night. You should do this once each night for seven nights in a row, starting tonight, and you should try to talk for at least three minutes each night." 
PROMOTING PARENTS' AND CHILDREN'S WELL-BEING

Appendix D

Parent Baseline Trait Gratitude: Gratitude Questionnarie-6

Please indicate how much you agree with each statement.

\begin{tabular}{|c|c|c|c|c|c|c|c|}
\hline & $\begin{array}{c}1 \\
\text { Strongly } \\
\text { Disagree }\end{array}$ & $\begin{array}{c}2 \\
\text { Disagree }\end{array}$ & $\begin{array}{c}3 \\
\text { Slightly } \\
\text { Disagree }\end{array}$ & $\begin{array}{c}4 \\
\text { Neutral }\end{array}$ & $\begin{array}{l}\quad 5 \\
\text { Slightly } \\
\text { Agree }\end{array}$ & $\begin{array}{c}6 \\
\text { Agree }\end{array}$ & $\begin{array}{l}7 \\
\text { Strongly } \\
\text { Agree }\end{array}$ \\
\hline $\begin{array}{l}\text { 1. I have so much in } \\
\text { life to be thankful } \\
\text { for. }\end{array}$ & & & & & & & \\
\hline $\begin{array}{l}\text { 2. If I had to list } \\
\text { everything that I } \\
\text { felt grateful for, it } \\
\text { would be a very } \\
\text { long list. }\end{array}$ & & & & & & & \\
\hline $\begin{array}{l}\text { 3. When I look at the } \\
\text { world, I don't see } \\
\text { much to be grateful } \\
\text { for. }\end{array}$ & & & & & & & \\
\hline $\begin{array}{l}\text { 4. I am grateful to a } \\
\text { wide variety of } \\
\text { people. }\end{array}$ & & & & & & & \\
\hline $\begin{array}{l}\text { 5. As I get older I find } \\
\text { myself more able } \\
\text { to appreciate the } \\
\text { people, events, } \\
\text { and situations that } \\
\text { have been part of } \\
\text { my life history. }\end{array}$ & & & & & & & \\
\hline $\begin{array}{l}\text { 6. Long amounts of } \\
\text { time can go by } \\
\text { before I feel } \\
\text { grateful to } \\
\text { something or } \\
\text { someone. }\end{array}$ & & & & & & & \\
\hline
\end{tabular}


Appendix E

Child Baseline Trait Gratitude: Adapted Gratitude Questionnarie-6

Please tell how much you agree with each statement.

\begin{tabular}{|c|c|c|c|c|c|c|}
\hline \multicolumn{7}{|c|}{ 1. I have so much in life to be thankful for. } \\
\hline $\begin{array}{c}1 \\
\text { Strongly } \\
\text { Disagree }\end{array}$ & $\begin{array}{c}2 \\
\text { Disagree }\end{array}$ & $\begin{array}{c}3 \\
\text { Slightly } \\
\text { Disagree }\end{array}$ & $\begin{array}{c}4 \\
\text { Neutral }\end{array}$ & $\begin{array}{c}5 \\
\text { Slightly } \\
\text { Agree }\end{array}$ & $\begin{array}{c}6 \\
\text { Agree }\end{array}$ & $\begin{array}{c}7 \\
\text { Strongly } \\
\text { Agree }\end{array}$ \\
\hline \multicolumn{7}{|c|}{ 2. If I had to list everything that I felt thankful for, it would be a very long list. } \\
\hline $\begin{array}{c}1 \\
\text { Strongly } \\
\text { Disagree }\end{array}$ & $\begin{array}{c}2 \\
\text { Disagree }\end{array}$ & $\begin{array}{c}3 \\
\text { Slightly } \\
\text { Disagree }\end{array}$ & $\begin{array}{c}4 \\
\text { Neutral }\end{array}$ & $\begin{array}{c}5 \\
\text { Slightly } \\
\text { Agree }\end{array}$ & $\begin{array}{c}6 \\
\text { Agree }\end{array}$ & $\begin{array}{c}7 \\
\text { Strongly } \\
\text { Agree }\end{array}$ \\
\hline
\end{tabular}

3. When I look at the world, I don't see much to be thankful for.

\begin{tabular}{|c|c|c|c|c|c|c|}
\hline $\begin{array}{c}1 \\
\text { Strongly } \\
\text { Disagree }\end{array}$ & $\begin{array}{c}2 \\
\text { Disagree }\end{array}$ & $\begin{array}{c}3 \\
\text { Slightly } \\
\text { Disagree }\end{array}$ & $\begin{array}{c}4 \\
\text { Neutral }\end{array}$ & $\begin{array}{c}5 \\
\text { Slightly } \\
\text { Agree }\end{array}$ & $\begin{array}{c}6 \\
\text { Agree }\end{array}$ & $\begin{array}{c}7 \\
\text { Strongly } \\
\text { Agree }\end{array}$ \\
\hline \multicolumn{7}{|c|}{ 4. I am thankful to a wide variety of people. } \\
\hline $\begin{array}{c}1 \\
\text { Strongly } \\
\text { Disagree }\end{array}$ & $\begin{array}{c}2 \\
\text { Disagree }\end{array}$ & $\begin{array}{c}3 \\
\text { Slightly } \\
\text { Disagree }\end{array}$ & $\begin{array}{c}4 \\
\text { Neutral }\end{array}$ & $\begin{array}{c}5 \\
\text { Slightly } \\
\text { Agree }\end{array}$ & $\begin{array}{c}6 \\
\text { Agree }\end{array}$ & $\begin{array}{c}7 \\
\text { Strongly } \\
\text { Agree }\end{array}$ \\
\hline
\end{tabular}

5. As I get older I find myself more able to appreciate the people, events, and situations that have been part of my life history.

\begin{tabular}{ccccccc}
1 & 2 & 3 & 4 & 5 & 6 & 7 \\
$\begin{array}{c}\text { Strongly } \\
\text { Disagree }\end{array}$ & Disagree & $\begin{array}{c}\text { Slightly } \\
\text { Disagree }\end{array}$ & Neutral & $\begin{array}{c}\text { Slightly } \\
\text { Agree }\end{array}$ & Agree & $\begin{array}{c}\text { Strongly } \\
\text { Agree }\end{array}$ \\
\hline
\end{tabular}




\section{Appendix F}

\section{Parent Baseline Emotional Well-Being: Satisfaction with Life Scale}

Below are five statements that you may agree or disagree with. Using the 1 - 7 scale below, indicate your agreement with each item by placing the appropriate number on the line preceding that item. Please be open and honest in your responding.

\begin{tabular}{|c|c|c|c|c|c|c|c|}
\hline & $\begin{array}{c}1 \\
\text { Strongly } \\
\text { Disagree }\end{array}$ & $\begin{array}{c}2 \\
\text { Disagree }\end{array}$ & $\begin{array}{c}3 \\
\text { Slightly } \\
\text { Disagree }\end{array}$ & $\begin{array}{c}4 \\
\text { Neither } \\
\text { Agree } \\
\text { nor } \\
\text { Disagree }\end{array}$ & $\begin{array}{l}\quad 5 \\
\text { Slightly } \\
\text { Agree }\end{array}$ & $\begin{array}{c}6 \\
\text { Agree }\end{array}$ & $\begin{array}{c}7 \\
\text { Strongly } \\
\text { Agree }\end{array}$ \\
\hline $\begin{array}{l}\text { 1. In most ways my } \\
\text { life is close to my } \\
\text { ideal. }\end{array}$ & & & & & & & \\
\hline $\begin{array}{l}\text { 2. The conditions of } \\
\text { my life are } \\
\text { excellent. }\end{array}$ & & & & & & & \\
\hline $\begin{array}{l}\text { 3. I am satisfied with } \\
\text { my life. }\end{array}$ & & & & & & & \\
\hline $\begin{array}{l}\text { 4. So far I have } \\
\text { gotten the } \\
\text { important things I } \\
\text { want in life. }\end{array}$ & & & & & & & \\
\hline $\begin{array}{l}\text { 5. If I could live my } \\
\text { life over, I would } \\
\text { change almost } \\
\text { nothing. }\end{array}$ & & & & & & & \\
\hline
\end{tabular}




\section{Appendix G}

\section{Child Baseline Emotional Well-Being: Students’ Life Satisfaction Scale}

Directions: We would like to know what thoughts about life you have had during the past several weeks. Think about how you spend each day and night and then think about how your life has been during most of this time. Here are some questions that ask you to indicate your satisfaction with your overall life. Circle the words next to each statement that indicate the extent to which you agree or disagree with each statement. For example, if you Strongly Agree with the statement "Life is great," you would circle those words on the following sample item:

\begin{tabular}{cccccc}
\hline Life is great. & & & & & \\
Strongly & Moderately & Mildly & Mildly & Moderately & Strongly \\
Disagree & Disagree & Disagree & Agree & Agree & Agree \\
\hline
\end{tabular}

It is important to know what you REALLY think, so please answer the questions the way you really think, not how you should think. This is NOT a test. There are NO right or wrong answers. 1. My life is going well.

$\begin{array}{cccccc}\text { Strongly } & \text { Moderately } & \text { Mildly } & \text { Mildly } & \text { Moderately } & \text { Strongly } \\ \text { Disagree } & \text { Disagree } & \text { Disagree } & \text { Agree } & \text { Agree } & \text { Agree }\end{array}$

2. My life is just right.

$\begin{array}{cccccc}\text { Strongly } & \text { Moderately } & \text { Mildly } & \text { Mildly } & \text { Moderately } & \text { Strongly } \\ \text { Disagree } & \text { Disagree } & \text { Disagree } & \text { Agree } & \text { Agree } & \text { Agree }\end{array}$

3. I would like to change many things in my life.

\begin{tabular}{|c|c|c|c|c|}
\hline $\begin{array}{l}\text { Strongly } \\
\text { Disagree }\end{array}$ & $\begin{array}{c}\text { Moderately } \\
\text { Disagree }\end{array}$ & $\begin{array}{c}\text { Mildly } \\
\text { Disagree }\end{array}$ & $\begin{array}{l}\text { Mildly } \\
\text { Agree }\end{array}$ & $\begin{array}{c}\text { Moderately } \\
\text { Agree }\end{array}$ \\
\hline
\end{tabular}

4. I wish I had a different kind of life.

$\begin{array}{cccccc}\text { Strongly } & \text { Moderately } & \text { Mildly } & \text { Mildly } & \text { Moderately } & \text { Strongly } \\ \text { Disagree } & \text { Disagree } & \text { Disagree } & \text { Agree } & \text { Agree } & \text { Agree }\end{array}$

5. I have a good life.

\begin{tabular}{|c|c|c|c|c|}
\hline $\begin{array}{l}\text { Strongly } \\
\text { Disagree }\end{array}$ & $\begin{array}{c}\text { Moderately } \\
\text { Disagree }\end{array}$ & $\begin{array}{c}\text { Mildly } \\
\text { Disagree }\end{array}$ & $\begin{array}{l}\text { Mildly } \\
\text { Aaree }\end{array}$ & $\begin{array}{c}\text { Moderately } \\
\text { Agree }\end{array}$ \\
\hline
\end{tabular}

6. I have what I want in life.

$\begin{array}{cccccc}\text { Strongly } & \text { Moderately } & \text { Mildly } & \text { Mildly } & \text { Moderately } & \text { Strongly } \\ \text { Disagree } & \text { Disagree } & \text { Disagree } & \text { Agree } & \text { Agree } & \text { Agree }\end{array}$

\begin{tabular}{|c|c|c|c|c|c|}
\hline $\begin{array}{l}\text { Strongly } \\
\text { Disagree }\end{array}$ & $\begin{array}{c}\text { Moderately } \\
\text { Disagree }\end{array}$ & $\begin{array}{c}\text { Mildly } \\
\text { Disagree }\end{array}$ & $\begin{array}{l}\text { Mildly } \\
\text { Agree }\end{array}$ & $\begin{array}{c}\text { Moderately } \\
\text { Agree }\end{array}$ & $\begin{array}{l}\text { Strongly } \\
\text { Agree }\end{array}$ \\
\hline
\end{tabular}


PROMOTING PARENTS' AND CHILDREN'S WELL-BEING

\section{Appendix $\mathrm{H}$}

Parent and Child Baseline Emotional Well-Being: Positive and Negative Mood

Please rate how much you feel each of the following ways in general.

\begin{tabular}{|c|c|c|c|c|c|c|c|c|c|c|}
\hline & $\begin{array}{c}1 \\
\text { Very } \\
\text { Slightly } \\
\text { or Not } \\
\text { at All }\end{array}$ & 2 & 3 & 4 & 5 & 6 & 7 & 8 & 9 & $\begin{array}{c}10 \\
\text { Extremely }\end{array}$ \\
\hline Ashamed & 0 & 0 & 0 & 0 & 0 & 0 & 0 & 0 & 0 & 0 \\
\hline Excited & 0 & 0 & 0 & 0 & 0 & 0 & 0 & 0 & 0 & 0 \\
\hline Upset & 0 & 0 & 0 & 0 & 0 & 0 & 0 & 0 & 0 & 0 \\
\hline Calm & 0 & 0 & 0 & 0 & 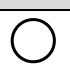 & 0 & 0 & 0 & 0 & $\bigcirc$ \\
\hline Scared & 0 & 0 & 0 & 0 & 0 & 0 & 0 & 0 & 0 & 0 \\
\hline Happy & 0 & 0 & 0 & 0 & $\bigcirc$ & 0 & 0 & 0 & 0 & $\bigcirc$ \\
\hline Proud & 0 & 0 & 0 & 0 & 0 & 0 & 0 & 0 & 0 & 0 \\
\hline Sad & 0 & 0 & 0 & 0 & $\bigcirc$ & $\bigcirc$ & 0 & 0 & 0 & $\bigcirc$ \\
\hline Cheerful & 0 & 0 & 0 & 0 & 0 & 0 & 0 & 0 & 0 & 0 \\
\hline Nervous & 0 & 0 & 0 & $\bigcirc$ & $\bigcirc$ & 0 & 0 & 0 & $\bigcirc$ & $\bigcirc$ \\
\hline Mad & 0 & 0 & 0 & 0 & 0 & 0 & 0 & 0 & 0 & 0 \\
\hline Joyful & 0 & 0 & 0 & 0 & $\bigcirc$ & 0 & $\bigcirc$ & 0 & 0 & $\bigcirc$ \\
\hline
\end{tabular}


Appendix I

\section{Parent Motivation: Adapted from the Parent Motivation Inventory}

The following questions ask about your thoughts on your own and your child's gratitude or thankfulness. Some of the questions also ask you to think about the conversation task that you and your child should do each night for the next week. Please indicate how much you agree with each statement.

\begin{tabular}{|c|c|c|c|c|c|c|}
\hline & $\begin{array}{c}1 \\
\text { Strongly } \\
\text { Disagree }\end{array}$ & $\begin{array}{l}2 \\
\text { Moderately } \\
\text { Disagree }\end{array}$ & $\begin{array}{c}3 \\
\text { Mildly } \\
\text { Disagree }\end{array}$ & $\begin{array}{c}4 \\
\text { Mildly } \\
\text { Agree }\end{array}$ & $\begin{array}{l}5 \\
\text { Moderately } \\
\text { Agree }\end{array}$ & $\begin{array}{c}6 \\
\text { Strongly } \\
\text { Agree }\end{array}$ \\
\hline $\begin{array}{l}\text { 1. I want my OWN gratitude to } \\
\text { increase. }\end{array}$ & 0 & 0 & 0 & 0 & 0 & 0 \\
\hline $\begin{array}{l}\text { 2. I believe that doing this } \\
\text { conversation task with my } \\
\text { child will increase my OWN } \\
\text { gratitude. }\end{array}$ & 0 & 0 & 0 & 0 & 0 & 0 \\
\hline $\begin{array}{l}\text { 3. I am motivated to do this } \\
\text { conversation task with my } \\
\text { child at home each night for } \\
\text { the upcoming week to } \\
\text { increase my OWN gratitude. }\end{array}$ & 0 & 0 & 0 & 0 & 0 & 0 \\
\hline $\begin{array}{l}\text { 4. I want my CHILD'S gratitude } \\
\text { to increase. }\end{array}$ & 0 & 0 & 0 & 0 & 0 & 0 \\
\hline $\begin{array}{l}\text { 5. I believe that doing this } \\
\text { conversation task with my } \\
\text { child will increase my } \\
\text { CHILD'S gratitude. }\end{array}$ & 0 & 0 & 0 & 0 & 0 & 0 \\
\hline $\begin{array}{l}\text { 6. I am motivated to do this } \\
\text { conversation task with my } \\
\text { child at home each night for } \\
\text { the upcoming week to } \\
\text { increase my CHILD'S } \\
\text { gratitude. }\end{array}$ & 0 & 0 & 0 & $\bigcirc$ & 0 & 0 \\
\hline
\end{tabular}


PROMOTING PARENTS' AND CHILDREN'S WELL-BEING

Appendix $\mathbf{J}$

Parent and Child Daily State Gratitude: Gratitude Adjectives Checklist

Please rate how much you have felt each of the following ways today.

\begin{tabular}{|l|c|c|c|c|c|c|c|c|c|c|}
\hline & $\begin{array}{c}1 \\
\text { Very } \\
\text { Slightly } \\
\text { or Not } \\
\text { at All }\end{array}$ & 2 & 3 & 4 & 5 & 6 & 7 & 8 & 9 & 10 \\
\hline Grateful & $\bigcirc$ & $\bigcirc$ & $\bigcirc$ & $\bigcirc$ & $\bigcirc$ & $\bigcirc$ & $\bigcirc$ & $\bigcirc$ & $\bigcirc$ & $\bigcirc$ \\
\hline Thankful & $\bigcirc$ & $\bigcirc$ & $\bigcirc$ & $\bigcirc$ & $\bigcirc$ & $\bigcirc$ & $\bigcirc$ & $\bigcirc$ & $\bigcirc$ & $\bigcirc$ \\
\hline Appreciative & $\bigcirc$ & $\bigcirc$ & $\bigcirc$ & $\bigcirc$ & $\bigcirc$ & $\bigcirc$ & $\bigcirc$ & $\bigcirc$ & $\bigcirc$ & $\bigcirc$ \\
\hline
\end{tabular}


PROMOTING PARENTS’ AND CHILDREN'S WELL-BEING

\section{Appendix K}

\section{Parent Daily Relationship Satisfaction}

The questions below ask about your relationship with your child today. Please fill in a circle for each question.

\begin{tabular}{|c|c|c|c|c|c|c|c|c|}
\hline & $\begin{array}{c}0 \\
\text { Not } \\
\text { At } \\
\text { All }\end{array}$ & $\begin{array}{l}1 \\
\text { Hardly } \\
\text { At All }\end{array}$ & $\begin{array}{c}2 \\
\text { Not } \\
\text { Too } \\
\text { Much }\end{array}$ & $\begin{array}{c}3 \\
\text { A } \\
\text { Little }\end{array}$ & $\begin{array}{c}4 \\
\text { Some } \\
\text { what }\end{array}$ & $\begin{array}{c}5 \\
\text { Quite } \\
\text { a Bit }\end{array}$ & $\begin{array}{c}6 \\
\text { Very } \\
\text { Much }\end{array}$ & $\begin{array}{c}7 \\
\text { Extre } \\
\text { mely } \\
\text { Much }\end{array}$ \\
\hline $\begin{array}{l}\text { 1. How happy have you been } \\
\text { with your relationship with } \\
\text { your child today? }\end{array}$ & & & & & & & & \\
\hline $\begin{array}{l}\text { 2. How much do you like the } \\
\text { way things have been } \\
\text { between you and your child } \\
\text { today? }\end{array}$ & & & & & & & & \\
\hline $\begin{array}{l}\text { 3. How satisfied have you } \\
\text { been with your relationship } \\
\text { with your child today? }\end{array}$ & 0 & $\cap$ & $\cap$ & ? & $\cap$ & $\cap$ & $\cap$ & $\cap$ \\
\hline
\end{tabular}


PROMOTING PARENTS' AND CHILDREN'S WELL-BEING

Appendix L

\section{Child Daily Relationship Satisfaction}

The questions below ask about your relationship with your parent today. Please fill in a circle for each question.

\begin{tabular}{|l|c|c|c|c|c|c|c|c|}
\hline & 0 & 1 & 2 & 3 & 4 & 5 & 6 & 7 \\
\hline $\begin{array}{c}\text { Not } \\
\text { At } \\
\text { All }\end{array}$ & $\begin{array}{c}\text { Hardly } \\
\text { At All }\end{array}$ & $\begin{array}{c}\text { Not } \\
\text { Too } \\
\text { Much }\end{array}$ & $\begin{array}{c}\text { A } \\
\text { Little }\end{array}$ & $\begin{array}{c}\text { Some } \\
\text { what }\end{array}$ & $\begin{array}{c}\text { Quite } \\
\text { a Bit }\end{array}$ & $\begin{array}{c}\text { Very } \\
\text { Much }\end{array}$ & $\begin{array}{c}\text { Extre } \\
\text { mely } \\
\text { Much }\end{array}$ \\
\hline $\begin{array}{l}\text { 1. How happy have you been } \\
\text { with your relationship with } \\
\text { your parent today? }\end{array}$ & $\bigcirc$ & $\bigcirc$ & $\bigcirc$ & $\bigcirc$ & $\bigcirc$ & $\bigcirc$ & $\bigcirc$ & $\bigcirc$ \\
\hline $\begin{array}{l}\text { 2. How much do you like the } \\
\text { way things have been } \\
\text { between you and your } \\
\text { parent today? }\end{array}$ & $\bigcirc$ & $\bigcirc$ & $\bigcirc$ & $\bigcirc$ & $\bigcirc$ & $\bigcirc$ & $\bigcirc$ & $\bigcirc$ \\
\hline $\begin{array}{l}\text { How satisfied have you } \\
\text { been with your relationship } \\
\text { with your parent today? }\end{array}$ & $\bigcirc$ & $\bigcirc$ & $\bigcirc$ & $\bigcirc$ & $\bigcirc$ & $\bigcirc$ & $\bigcirc$ & $\bigcirc$ \\
\hline
\end{tabular}


PROMOTING PARENTS' AND CHILDREN'S WELL-BEING

Appendix M

Parent Daily Emotional Well-Being

Please indicate how much you agree with the following statement.

\begin{tabular}{|l|c|c|c|c|c|c|c|}
\hline & $\begin{array}{c}1 \\
\text { Strongly } \\
\text { Disagree }\end{array}$ & $\begin{array}{c}2 \\
\text { Disagree }\end{array}$ & $\begin{array}{c}3 \\
\text { Slightly } \\
\text { Disagree }\end{array}$ & $\begin{array}{c}4 \\
\text { Neither } \\
\text { Agree } \\
\text { nor } \\
\text { Disagree }\end{array}$ & $\begin{array}{c}5 \\
\text { Slightly } \\
\text { Agree }\end{array}$ & $\begin{array}{c}6 \\
\text { Agree }\end{array}$ & $\begin{array}{c}7 \\
\text { Strongly } \\
\text { Agree }\end{array}$ \\
\hline $\begin{array}{l}\text { I am satisfied with my } \\
\text { life today }\end{array}$ & 0 & $\bigcirc$ & $\bigcirc$ & $\bigcirc$ & $\bigcirc$ & $\bigcirc$ & $\bigcirc$ \\
\hline
\end{tabular}

Please rate how much you have felt each of the following ways today.

\begin{tabular}{|l|c|c|c|c|c|c|c|c|c|c|}
\hline & $\begin{array}{c}1 \\
\text { Very } \\
\text { Slightly } \\
\text { or Not } \\
\text { at All }\end{array}$ & 2 & 3 & 4 & 5 & 6 & 7 & 8 & 9 & $\begin{array}{c}10 \\
\text { Extremely }\end{array}$ \\
\hline Ashamed & $\bigcirc$ & $\bigcirc$ & $\bigcirc$ & $\bigcirc$ & $\bigcirc$ & $\bigcirc$ & $\bigcirc$ & $\bigcirc$ & $\bigcirc$ & $\bigcirc$ \\
\hline Excited & $\bigcirc$ & $\bigcirc$ & $\bigcirc$ & $\bigcirc$ & $\bigcirc$ & $\bigcirc$ & $\bigcirc$ & $\bigcirc$ & $\bigcirc$ & $\bigcirc$ \\
\hline Upset & $\bigcirc$ & $\bigcirc$ & $\bigcirc$ & $\bigcirc$ & $\bigcirc$ & $\bigcirc$ & $\bigcirc$ & $\bigcirc$ & $\bigcirc$ & $\bigcirc$ \\
\hline Calm & $\bigcirc$ & $\bigcirc$ & $\bigcirc$ & $\bigcirc$ & $\bigcirc$ & $\bigcirc$ & $\bigcirc$ & $\bigcirc$ & $\bigcirc$ & $\bigcirc$ \\
\hline Scared & $\bigcirc$ & $\bigcirc$ & $\bigcirc$ & $\bigcirc$ & $\bigcirc$ & $\bigcirc$ & $\bigcirc$ & $\bigcirc$ & $\bigcirc$ & $\bigcirc$ \\
\hline Happy & $\bigcirc$ & $\bigcirc$ & $\bigcirc$ & $\bigcirc$ & $\bigcirc$ & $\bigcirc$ & $\bigcirc$ & $\bigcirc$ & $\bigcirc$ & $\bigcirc$ \\
\hline Proud & $\bigcirc$ & $\bigcirc$ & $\bigcirc$ & $\bigcirc$ & $\bigcirc$ & $\bigcirc$ & $\bigcirc$ & $\bigcirc$ & $\bigcirc$ & $\bigcirc$ \\
\hline Sad & $\bigcirc$ & $\bigcirc$ & $\bigcirc$ & $\bigcirc$ & $\bigcirc$ & $\bigcirc$ & $\bigcirc$ & $\bigcirc$ & $\bigcirc$ & $\bigcirc$ \\
\hline Cheerful & $\bigcirc$ & $\bigcirc$ & $\bigcirc$ & $\bigcirc$ & $\bigcirc$ & $\bigcirc$ & $\bigcirc$ & $\bigcirc$ & $\bigcirc$ & $\bigcirc$ \\
\hline Nervous & $\bigcirc$ & $\bigcirc$ & $\bigcirc$ & $\bigcirc$ & $\bigcirc$ & $\bigcirc$ & $\bigcirc$ & $\bigcirc$ & $\bigcirc$ & $\bigcirc$ \\
\hline Mad & $\bigcirc$ & $\bigcirc$ & $\bigcirc$ & $\bigcirc$ & $\bigcirc$ & $\bigcirc$ & $\bigcirc$ & $\bigcirc$ & $\bigcirc$ & $\bigcirc$ \\
\hline Joyful & $\bigcirc$ & $\bigcirc$ & $\bigcirc$ & $\bigcirc$ & $\bigcirc$ & $\bigcirc$ & $\bigcirc$ & $\bigcirc$ & $\bigcirc$ & $\bigcirc$ \\
\hline
\end{tabular}


PROMOTING PARENTS' AND CHILDREN'S WELL-BEING

\section{Appendix N}

\section{Child Daily Emotional Well-Being}

Please tell how much you agree or disagree with this statement.

\section{My life has gone well today.}

Strongly Moderately

Disagree

Disagree

Mildly

Disagree

Mildly

Agree

Moderately

Strongly

Agree

Please rate how much you have felt each of the following ways today.

\begin{tabular}{|l|c|c|c|c|c|c|c|c|c|c|}
\hline & $\begin{array}{c}1 \\
\text { Very } \\
\text { Slightly } \\
\text { or Not } \\
\text { at All }\end{array}$ & 2 & 3 & 4 & 5 & 6 & 7 & 8 & 9 & $\begin{array}{c}10 \\
\text { Extremely }\end{array}$ \\
\hline Ashamed & $\bigcirc$ & $\bigcirc$ & $\bigcirc$ & $\bigcirc$ & $\bigcirc$ & $\bigcirc$ & $\bigcirc$ & $\bigcirc$ & $\bigcirc$ & $\bigcirc$ \\
\hline Excited & $\bigcirc$ & $\bigcirc$ & $\bigcirc$ & $\bigcirc$ & $\bigcirc$ & $\bigcirc$ & $\bigcirc$ & $\bigcirc$ & $\bigcirc$ & $\bigcirc$ \\
\hline Upset & $\bigcirc$ & $\bigcirc$ & $\bigcirc$ & $\bigcirc$ & $\bigcirc$ & $\bigcirc$ & $\bigcirc$ & $\bigcirc$ & $\bigcirc$ & $\bigcirc$ \\
\hline Calm & $\bigcirc$ & $\bigcirc$ & $\bigcirc$ & $\bigcirc$ & $\bigcirc$ & $\bigcirc$ & $\bigcirc$ & $\bigcirc$ & $\bigcirc$ & $\bigcirc$ \\
\hline Scared & $\bigcirc$ & $\bigcirc$ & $\bigcirc$ & $\bigcirc$ & $\bigcirc$ & $\bigcirc$ & $\bigcirc$ & $\bigcirc$ & $\bigcirc$ & $\bigcirc$ \\
\hline Happy & $\bigcirc$ & $\bigcirc$ & $\bigcirc$ & $\bigcirc$ & $\bigcirc$ & $\bigcirc$ & $\bigcirc$ & $\bigcirc$ & $\bigcirc$ & $\bigcirc$ \\
\hline Proud & $\bigcirc$ & $\bigcirc$ & $\bigcirc$ & $\bigcirc$ & $\bigcirc$ & $\bigcirc$ & $\bigcirc$ & $\bigcirc$ & $\bigcirc$ & $\bigcirc$ \\
\hline Sad & $\bigcirc$ & $\bigcirc$ & $\bigcirc$ & $\bigcirc$ & $\bigcirc$ & $\bigcirc$ & $\bigcirc$ & $\bigcirc$ & $\bigcirc$ & $\bigcirc$ \\
\hline Cheerful & $\bigcirc$ & $\bigcirc$ & $\bigcirc$ & $\bigcirc$ & $\bigcirc$ & $\bigcirc$ & $\bigcirc$ & $\bigcirc$ & $\bigcirc$ & $\bigcirc$ \\
\hline Nervous & $\bigcirc$ & $\bigcirc$ & $\bigcirc$ & $\bigcirc$ & $\bigcirc$ & $\bigcirc$ & $\bigcirc$ & $\bigcirc$ & $\bigcirc$ & $\bigcirc$ \\
\hline Mad & $\bigcirc$ & $\bigcirc$ & $\bigcirc$ & $\bigcirc$ & $\bigcirc$ & $\bigcirc$ & $\bigcirc$ & $\bigcirc$ & $\bigcirc$ & $\bigcirc$ \\
\hline Joyful & $\bigcirc$ & $\bigcirc$ & $\bigcirc$ & $\bigcirc$ & $\bigcirc$ & $\bigcirc$ & $\bigcirc$ & $\bigcirc$ & $\bigcirc$ & $\bigcirc$ \\
\hline
\end{tabular}




\section{Appendix $\mathrm{O}$}

\section{Parent-Report of Parent-Child Closeness and Conflicts}

Please reflect on the degree to which each of the following statements currently applies to your relationship with your child.

\begin{tabular}{|c|c|c|c|c|c|c|}
\hline & & $\begin{array}{c}\text { Definitely } \\
\text { does not } \\
\text { apply } \\
1\end{array}$ & Not really & $\begin{array}{c}\text { Neutral, } \\
\text { not sure } \\
3 \\
\end{array}$ & $\begin{array}{c}\text { Applies } \\
\text { somewhat } \\
4\end{array}$ & $\begin{array}{c}\text { Definitely } \\
\text { applies } \\
5\end{array}$ \\
\hline 1. & $\begin{array}{l}\text { I share an affectionate, warm relationship } \\
\text { with my child. }\end{array}$ & & & & & \\
\hline 2. & $\begin{array}{l}\text { My child and I always seem to be struggling } \\
\text { with each other. }\end{array}$ & & & & & \\
\hline 3. & If upset, my child will seek comfort from me. & & & & & \\
\hline 4. & $\begin{array}{l}\text { My child is uncomfortable with physical } \\
\text { affection or touch from me. }\end{array}$ & & & & & \\
\hline 5. & My child values his/her relationship with me. & & & & & \\
\hline 6. & $\begin{array}{l}\text { When I praise my child, he/she beams with } \\
\text { pride. }\end{array}$ & & & & & \\
\hline 7. & $\begin{array}{l}\text { My child spontaneously shares information } \\
\text { about himself/herself. }\end{array}$ & & & & & \\
\hline 8. & My child easily becomes angry at me. & & & & & \\
\hline 9. & $\begin{array}{l}\text { It is easy to be in tune with what my child is } \\
\text { feeling. }\end{array}$ & & & & & \\
\hline 10. & $\begin{array}{l}\text { My child remains angry or is resistant after } \\
\text { being disciplined. }\end{array}$ & & & & & \\
\hline 11. & Dealing with my child drains my energy. & & & & & \\
\hline 12. & $\begin{array}{l}\text { When my child is in a bad mood, I know } \\
\text { we're in for a long and difficult day. }\end{array}$ & & & & & \\
\hline 13. & $\begin{array}{l}\text { My child's feelings toward me can be } \\
\text { unpredictable or can change suddenly. }\end{array}$ & & & & & \\
\hline 14. & My child is sneaky or manipulative with me. & & & & & \\
\hline 15. & $\begin{array}{l}\text { My child openly shares his/her feelings and } \\
\text { experiences with me. }\end{array}$ & & & & & \\
\hline
\end{tabular}


PROMOTING PARENTS' AND CHILDREN'S WELL-BEING

Appendix P

\section{Parent Depressive Symptoms}

Below is a list of the ways you might have felt or acted. Please tell how much you have felt this way during the past week.

\begin{tabular}{|c|c|c|c|c|}
\hline 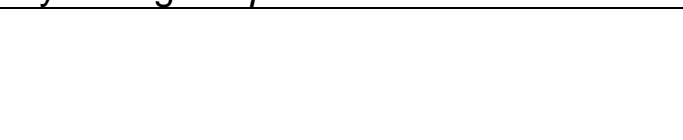 & $\begin{array}{l}\text { Rarely } \\
<1 \text { day }\end{array}$ & $\begin{array}{c}\text { Sometimes } \\
\text { 1-2 days }\end{array}$ & $\begin{array}{c}\text { Occasionally } \\
\text { 3-4 days }\end{array}$ & $\begin{array}{l}\text { Most of } \\
\text { the time } \\
5-7 \text { days }\end{array}$ \\
\hline I felt like I was moving too slowly. & $\mathrm{O}$ & $\mathrm{O}$ & $\mathrm{O}$ & $\mathrm{O}$ \\
\hline My appetite was poor. & $\mathrm{O}$ & $\mathrm{O}$ & $\mathrm{O}$ & $\mathrm{O}$ \\
\hline I lost interest in my usual activities. & $\mathrm{O}$ & $\mathrm{O}$ & $\mathrm{O}$ & $\mathrm{O}$ \\
\hline I felt like a bad person. & $\mathrm{O}$ & $\mathrm{O}$ & $\mathrm{O}$ & $\mathrm{O}$ \\
\hline I had a lot of trouble getting to sleep. & $\mathrm{O}$ & $\mathrm{O}$ & $\mathrm{O}$ & $\mathrm{O}$ \\
\hline I could not shake off the blues. & $\mathrm{O}$ & $\mathrm{O}$ & $\mathrm{O}$ & $\mathrm{O}$ \\
\hline $\begin{array}{l}\text { I had trouble keeping my mind on what } \\
\text { I was doing. }\end{array}$ & $\mathrm{O}$ & $\mathrm{O}$ & $\mathrm{O}$ & $\mathrm{O}$ \\
\hline I wished I were dead. & $\mathrm{O}$ & $\mathrm{O}$ & $\mathrm{O}$ & $\mathrm{O}$ \\
\hline Nothing made me happy. & $\mathrm{O}$ & $\mathrm{O}$ & $\mathrm{O}$ & $\mathrm{O}$ \\
\hline I felt depressed. & $\mathrm{O}$ & $\mathrm{O}$ & $\mathrm{O}$ & $\mathrm{O}$ \\
\hline My sleep was restless. & $\mathrm{O}$ & $\mathrm{O}$ & $\mathrm{O}$ & $\mathrm{O}$ \\
\hline I slept much more than usual. & $\mathrm{O}$ & $\mathrm{O}$ & $\mathrm{O}$ & $\mathrm{O}$ \\
\hline I felt fidgety. & $\mathrm{O}$ & $\mathrm{O}$ & $\mathrm{O}$ & $\mathrm{O}$ \\
\hline I lost a lot of weight without trying to. & $\mathrm{O}$ & $\mathrm{O}$ & $\mathrm{O}$ & $\mathrm{O}$ \\
\hline I did not like myself. & $\mathrm{O}$ & $\mathrm{O}$ & $\mathrm{O}$ & $\mathrm{O}$ \\
\hline I wanted to hurt myself. & $\mathrm{O}$ & $\mathrm{O}$ & $\mathrm{O}$ & $\mathrm{O}$ \\
\hline I was tired all the time. & $\mathrm{O}$ & $\mathrm{O}$ & $\mathrm{O}$ & $\mathrm{O}$ \\
\hline I felt sad. & $\mathrm{O}$ & $\mathrm{O}$ & $\mathrm{O}$ & $\mathrm{O}$ \\
\hline $\begin{array}{l}\text { I could not focus on the important } \\
\text { things. }\end{array}$ & $\mathrm{O}$ & $\mathrm{O}$ & $\mathrm{O}$ & $\mathrm{O}$ \\
\hline I could not get going. & $\mathrm{O}$ & $\mathrm{O}$ & 0 & 0 \\
\hline
\end{tabular}




\section{Appendix Q}

\section{Child Depressive Symptoms}

Below is a list of the ways you might have felt or acted. Please tell how much you have felt this way during the past week.

\begin{tabular}{|c|c|c|c|c|}
\hline 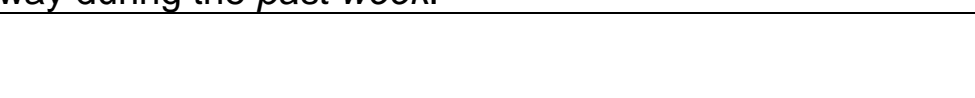 & $\begin{array}{l}\text { Not at } \\
\text { all }\end{array}$ & $\begin{array}{c}\text { A } \\
\text { little }\end{array}$ & Some & A lot \\
\hline 1. I was bothered by things that usually don't bother me. & $\mathrm{O}$ & $\mathrm{O}$ & $\mathrm{O}$ & $\mathrm{O}$ \\
\hline 2. I did not feel like eating, I wasn't very hungry. & $\mathrm{O}$ & O & O & $\mathrm{O}$ \\
\hline $\begin{array}{l}\text { 3. I wasn't able to feel happy, even when my family or } \\
\text { friends tried to help me feel better. }\end{array}$ & $\mathrm{O}$ & $\mathrm{O}$ & $\mathrm{O}$ & $\mathrm{O}$ \\
\hline 4. I felt like I was just as good as other kids. & $\mathrm{O}$ & $\mathrm{O}$ & $\mathrm{O}$ & $\mathrm{O}$ \\
\hline 5. I felt like I couldn't pay attention to what I was doing. & $\mathrm{O}$ & $\mathrm{O}$ & $\mathrm{O}$ & $\mathrm{O}$ \\
\hline 6. I felt down and unhappy. & $\mathrm{O}$ & $\mathrm{O}$ & $\mathrm{O}$ & $\mathrm{O}$ \\
\hline 7. I felt like I was too tired to do things. & $\mathrm{O}$ & $\mathrm{O}$ & $\mathrm{O}$ & $\mathrm{O}$ \\
\hline 8. I felt like something good was going to happen. & $\mathrm{O}$ & $\mathrm{O}$ & $\mathrm{O}$ & $\mathrm{O}$ \\
\hline 9. I felt like things I did before didn't work out right. & $\mathrm{O}$ & $\mathrm{O}$ & $\mathrm{O}$ & $\mathrm{O}$ \\
\hline 10. I felt scared. & $\mathrm{O}$ & $\mathrm{O}$ & $\mathrm{O}$ & $\mathrm{O}$ \\
\hline 11. I didn't sleep as well as I usually sleep. & $\mathrm{O}$ & $\mathrm{O}$ & $\mathrm{O}$ & $\mathrm{O}$ \\
\hline 12. I was happy. & $\mathrm{O}$ & $\mathrm{O}$ & $\mathrm{O}$ & $\mathrm{O}$ \\
\hline 13. I was more quiet than usual. & $\mathrm{O}$ & $\mathrm{O}$ & $\mathrm{O}$ & $\mathrm{O}$ \\
\hline 14. I felt lonely, like I didn't have any friends. & $\mathrm{O}$ & $\mathrm{O}$ & $\mathrm{O}$ & $\mathrm{O}$ \\
\hline $\begin{array}{l}\text { 15. I felt like kids I know were not friendly or that they } \\
\text { didn't want to be with me. }\end{array}$ & O & $\mathrm{O}$ & O & O \\
\hline 16. I had a good time. & $\mathrm{O}$ & $\mathrm{O}$ & $\mathrm{O}$ & $\mathrm{O}$ \\
\hline 17. I felt like crying. & $\mathrm{O}$ & O & $\mathrm{O}$ & $\mathrm{O}$ \\
\hline 18. I felt sad. & $\mathrm{O}$ & $\mathrm{O}$ & $\mathrm{O}$ & $\mathrm{O}$ \\
\hline 19. I felt people didn't like me. & $\mathrm{O}$ & $\mathrm{O}$ & $\mathrm{O}$ & $\mathrm{O}$ \\
\hline 20. It was hard to get started doing things. & $\mathrm{O}$ & O & $\mathrm{O}$ & $\mathrm{O}$ \\
\hline
\end{tabular}


Appendix R

Demographic Questions

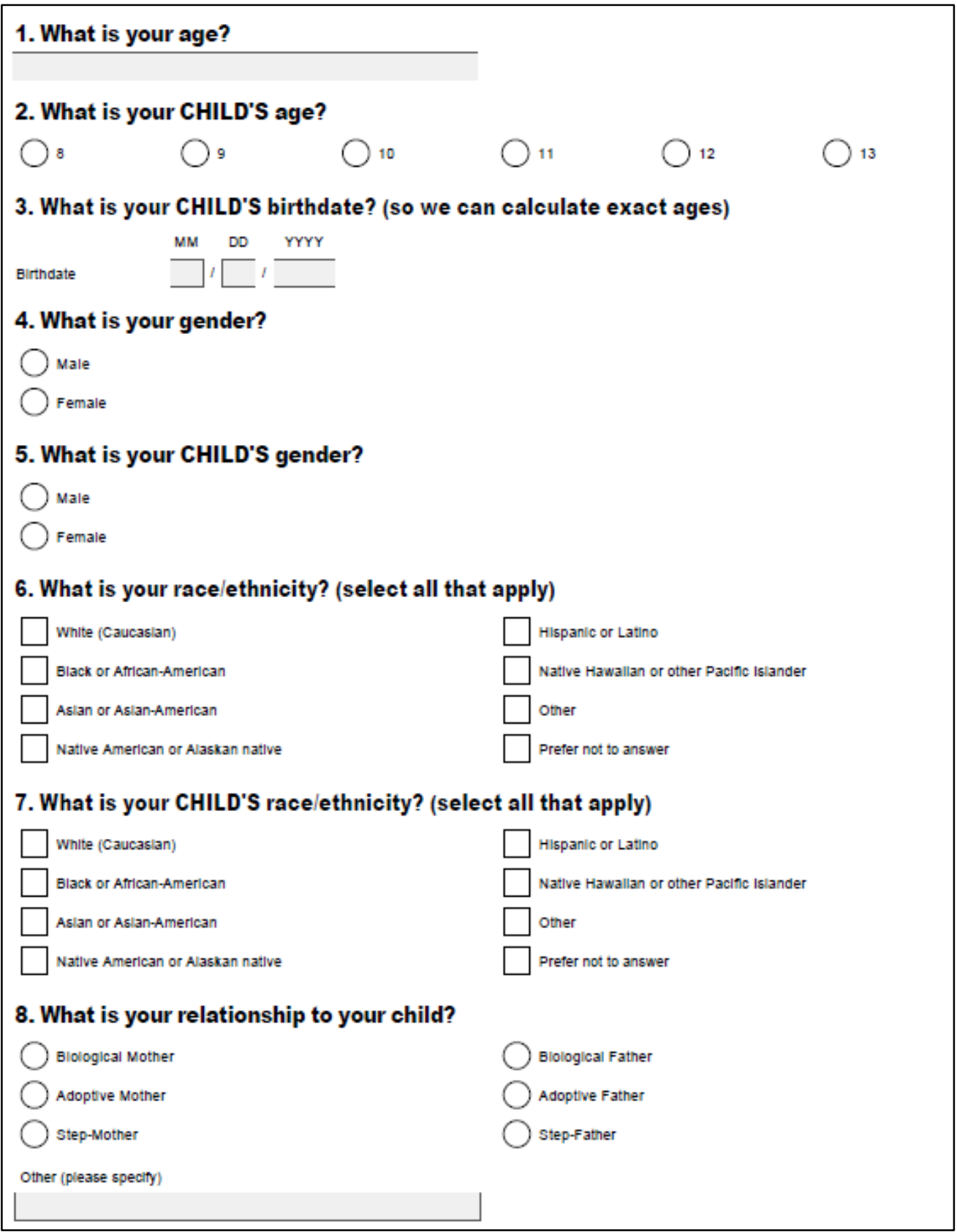


Demographic questions continued.

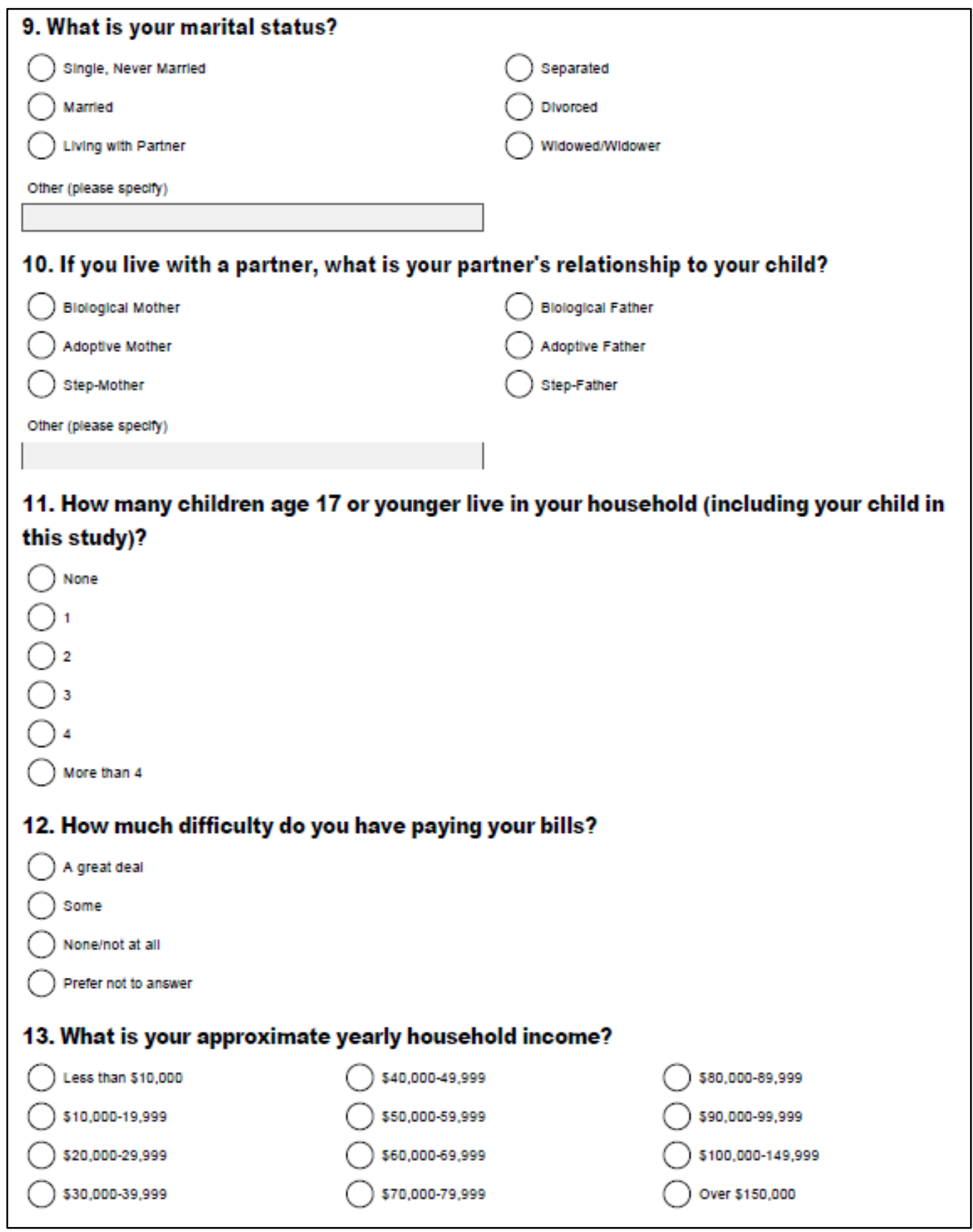


Demographic questions continued.

\begin{tabular}{|c|c|}
\hline \multicolumn{2}{|c|}{ 14. What is the highest level of education you have completed? } \\
\hline Less than high school diploma & Bachelor's degree \\
\hline High school diploma or GED & Master's degree \\
\hline Technical certificate & Professional degree \\
\hline Some college & Doctoral degree \\
\hline Assoclate's degree & efer not to \\
\hline
\end{tabular}

15. What is the highest level of education your PARTNER has completed?
Less than high school diploma
Bachelor's degree
High school dlploma or GED
Master's degree
Technical certificate
Professional degree
some college
$\bigcirc$ Doctoral degree
Assoclate's degree
Not appllicable

16. What is your religion?
Protestant Christlan
Musllm
Athelst
Evangellcal christlan
Mormon
Agnostlc
Roman Cathollic
Hindu
Jewish
Budahist
Other (please specily

17. How important is religion to you?
$\mathrm{O}_{1-\text { Not at all }} \mathrm{O}_{2}$
$\bigcirc_{3}$
$\bigcirc_{\text {Somewhat }}$ -
Somewhat
$\mathrm{S}$
○
$\bigcirc_{\text {Important }}^{7-\text { Extremely }}$ Important
Important

18. How often in the last month did you attend religious services or participate in any type of religious activity? (Please write in an approximate number.)

19. How often in the last month did your CHILD attend religious services or participate in any type of religious activity? (Please write in an approximate number.) 
Appendix S

\section{Parent-Report of Gratitude-Relevant Behaviors}

Gratitude-relevant questions highlighted.

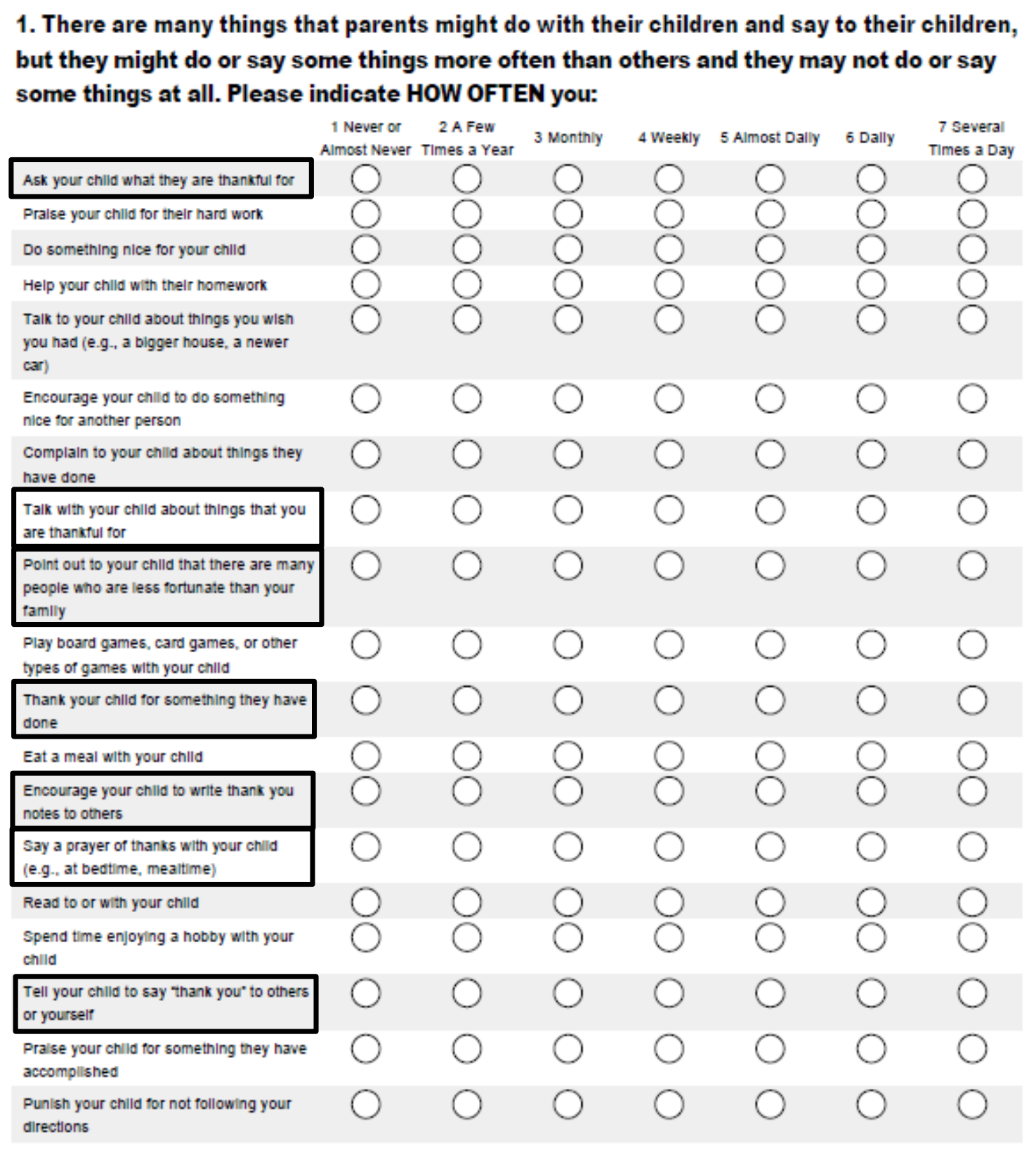




\section{Appendix T}

\section{Parents' Daily Questions about Conversation Task}

\section{Did you do the conversation task with your child tonight?}

Yes

No

2. About what time did you have the conversation task with your child?

3. About how long did you and your child talk during the conversation task?

4. Briefly describe what you and your child talked about during the conversation task. Provide SPECIFIC detail about what you mentioned and what your child mentioned.

5. When you think about tonight's conversation task, how much do you agree or disagree with the following statements?

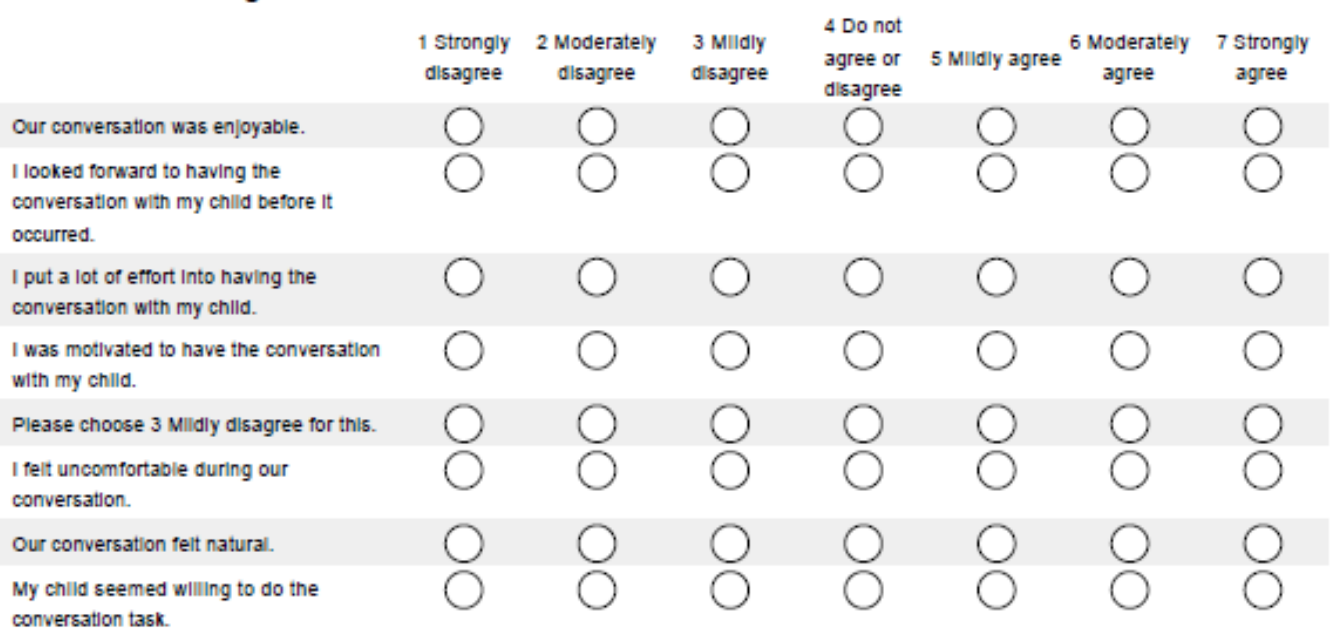

6. Did you engage in similar conversations with your child at other times during the day (besides your bedtime conversation)?
Yes, muitiple times throughout the day.
Yes, a couple of times throughout the day.
Yes, one other time today.
No, Just at bedtime.

If yes, brlefiy describe the other conversations. 


\section{Appendix U}

\section{Parent Day 7 and Follow-up Questions}

Day 7

7. We want to know how helpful the following things were in helping you remember to do the conversation task and surveys each night.

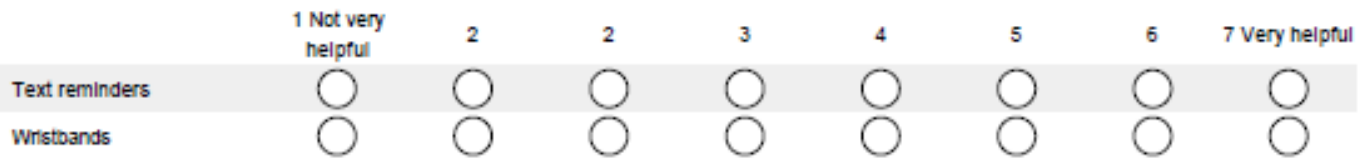

8. The following questions are about the wristbands we gave you.

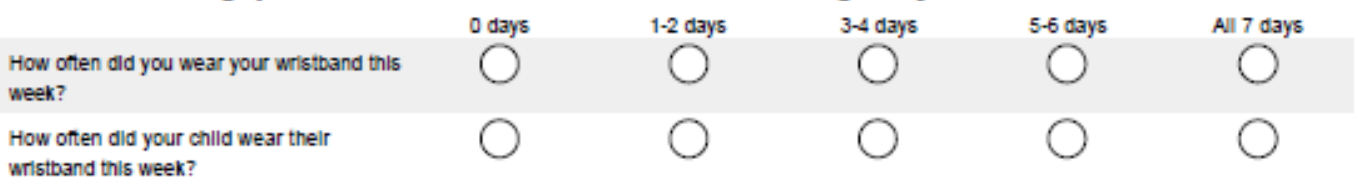

9. Thinking about the whole week and all of the conversations you have had with your child based on the topic you were given, how much do you think having the conversations with your child improved each of the following things:

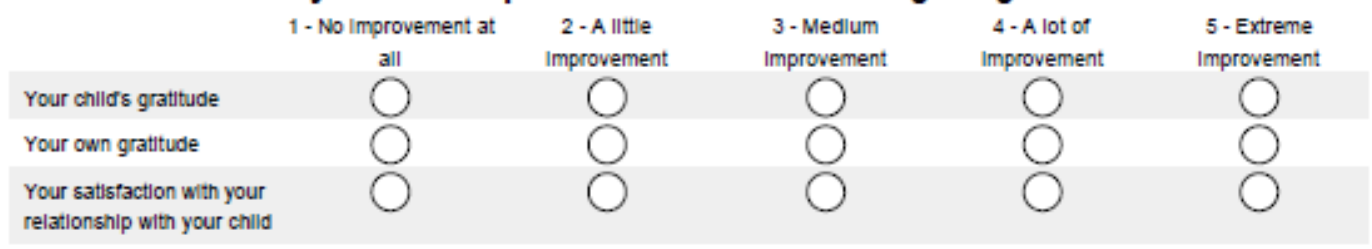

Do you think that having these conversations Impacted anything else for you or your chillo?

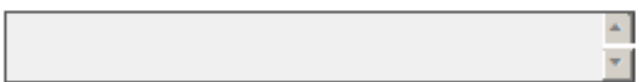

1. Do you plan to continue doing this conversation task with your child each night?

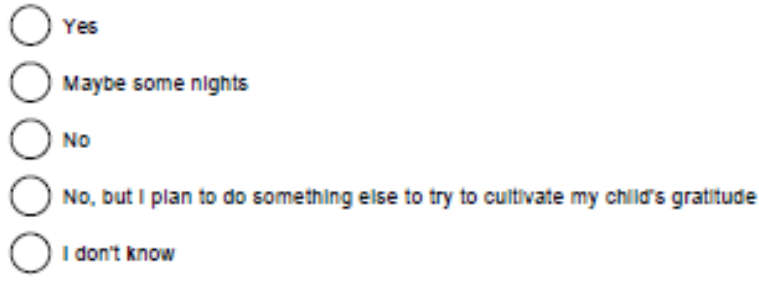


Follow-up

\section{Have you continued doing the conversation task with your child this PAST WEEK?}

Yes, every day for the past week.

Yes, 5 or 6 days out of the past week.

Yes, 3 or 4 days out of the past week.

Yes, 1 or 2 days out of the past week.

No, not at all.

No, but I have tried to do something else to cultivate my chlid's gratitude.

Please describe why this answer cholce is appropriate for you

\section{Do you plan to continue doing this conversation task with your child?}

Yes

Maybe some nights

(No

No, but I plan to do something else to try to cultivate my chlld's gratitude

( I don't know

Why did you choose this answer?

1. Do you have comments or feedback about any parts of the study? If so, please leave it here! 